$\frac{W}{M}$

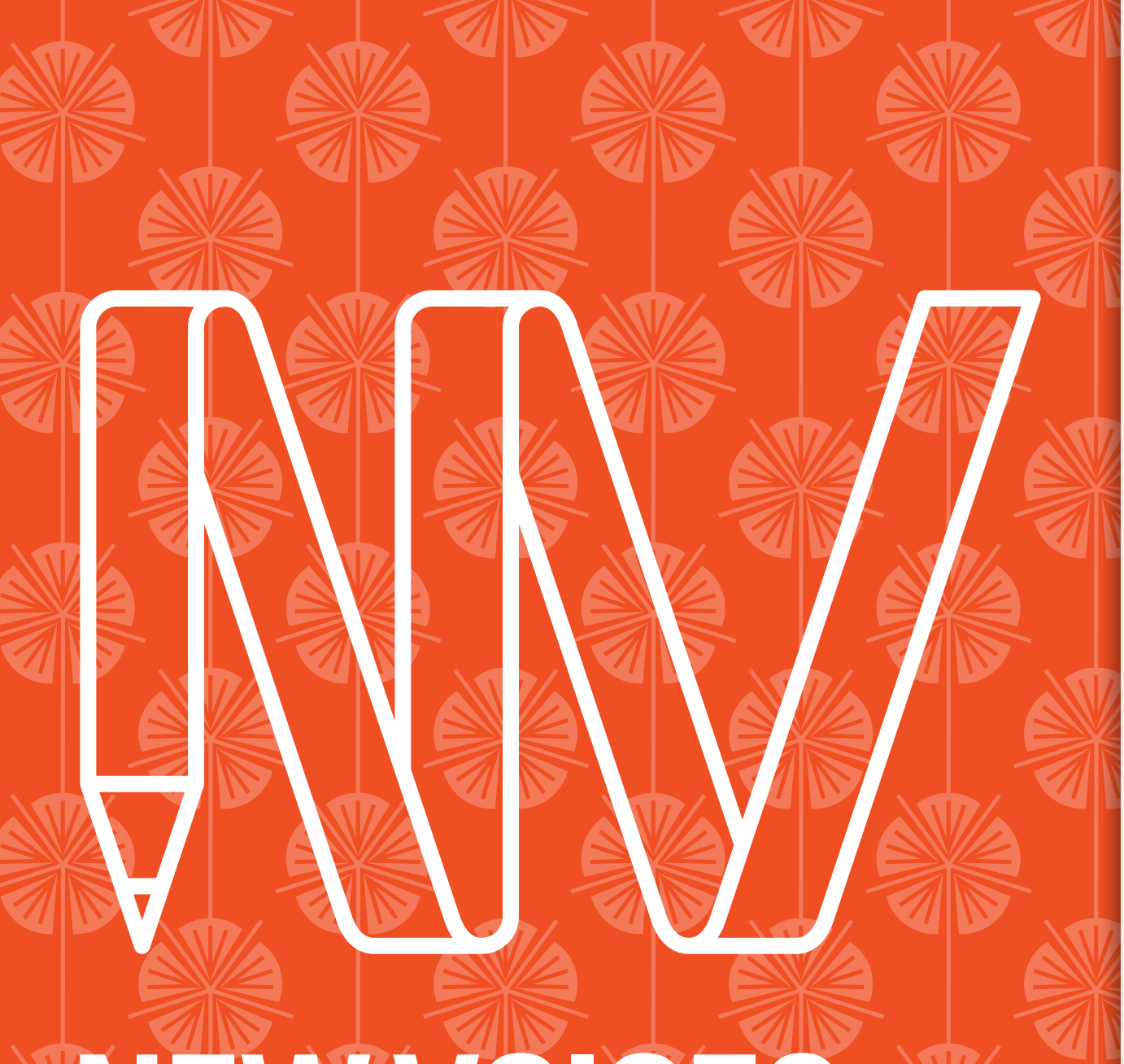

11

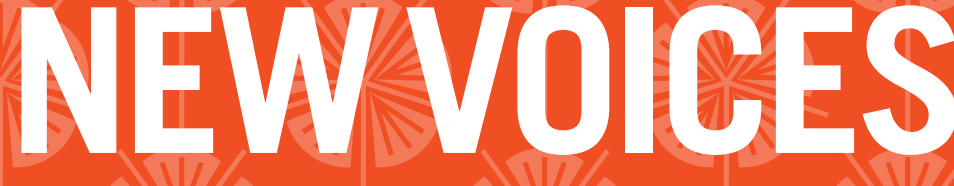

IN JAPANESESTUDIES
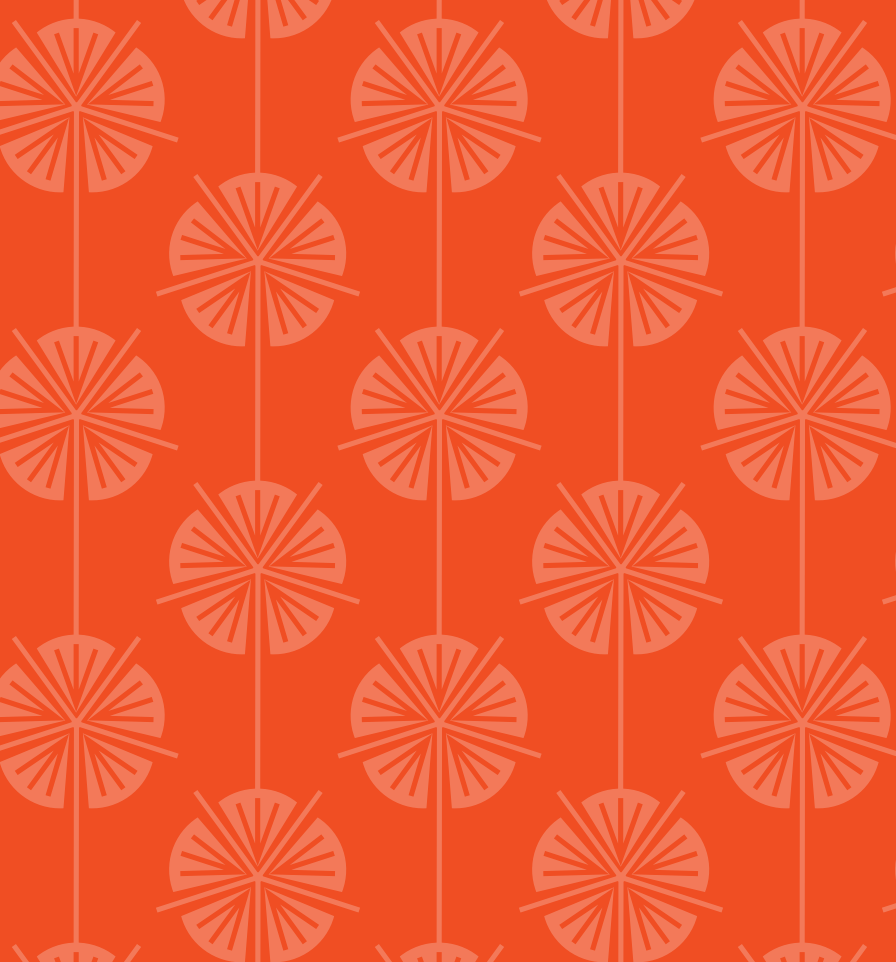

newvoices.org.au
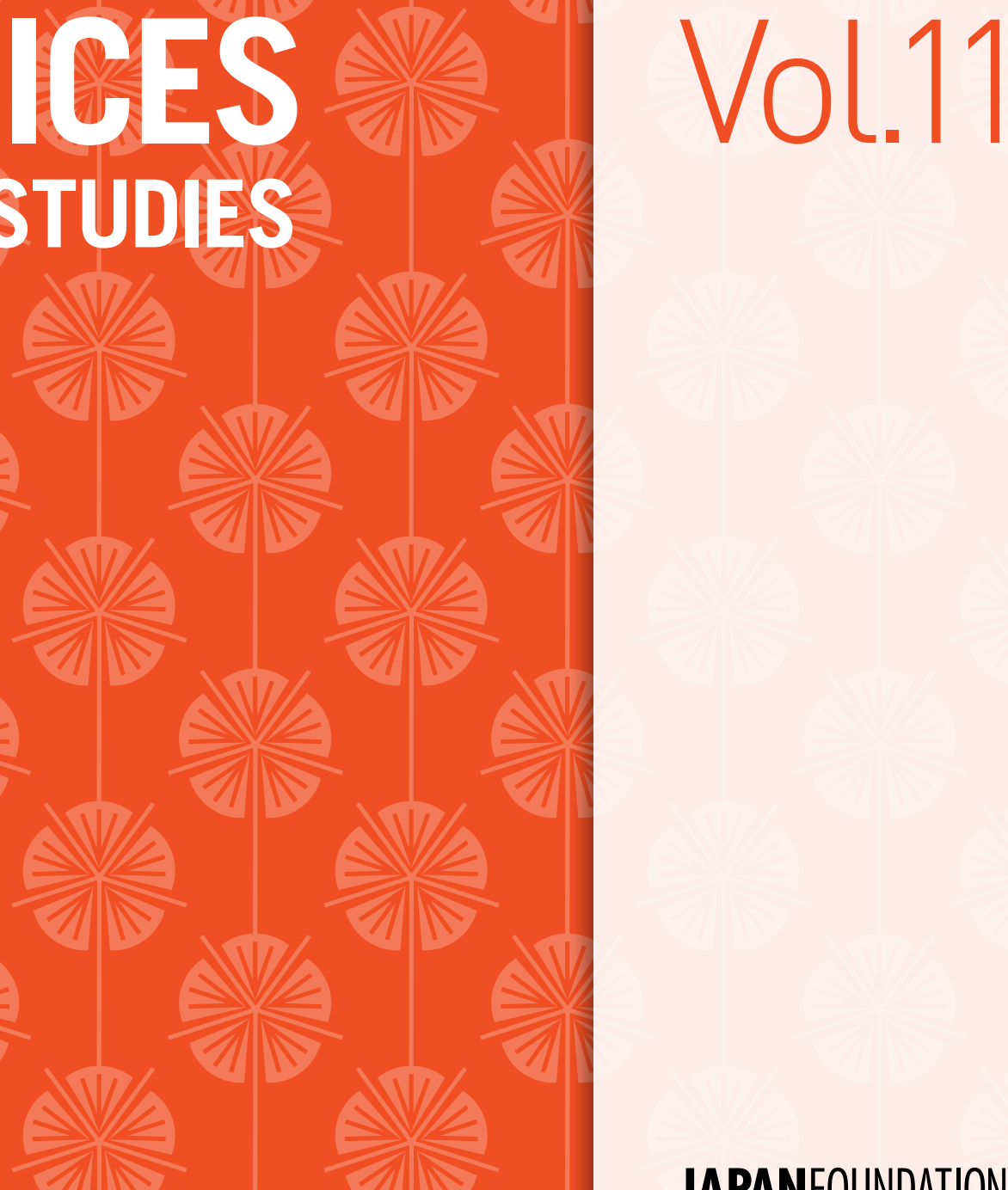

JAPANFOUNDATION 8

BRINGING JAPAN TO YOU 


\section{New Voices in Japanese Studies Volume 11}

\section{An interdisciplinary, peer-reviewed journal showcasing the work of emerging scholars with ties to Australia and New Zealand and research interests in Japan.}

GUEST EDITOR, VOLUME 11

Dr Emma Dalton, RMIT University

EDITORIAL ADVISORY BOARD (in alphabetical order)

Professor Kent Anderson, The University of Newcastle

Professor Brendan Barrett, Osaka University

Dr Alexander Brown, Japan Women's University

Dr Barbara Hartley, The University of Queensland

Dr Eric Hsu, The University of South Australia

Emeritus Professor Hiroji Isozaki, Iwate University

Associate Professor Kyoko Koma, Meiji University

Dr Stephanie Lavau, The University of Melbourne

Associate Professor Julian Lee, RMIT University

Dr Sally McLaren, UNSW Sydney

Professor Emerita Tessa Morris-Suzuki, Australian National University

Professor Kaori Okano, LaTrobe University

Dr Hironori Onuki, The University of Wollongong

Professor Hirofumi Tanada, Waseda University

Professor Gabriele Vogt, University of Hamburg

\section{SERIES EDITOR}

Elicia O'Reilly, The Japan Foundation, Sydney

All submissions to New Voices in Japanese Studies are peer reviewed by a board of independent academic experts to meet the HERDC requirements for refereed journal status. This and other volumes are available for download via the New Voices in Japanese Studies website, EBSCO Host, the Directory of Open Access Journals and Ingenta Connect.

www.newvoices.org.au | www.doaj.org | www.ingentaconnect.com

The views expressed in this journal are those of the authors, and do not necessarily coincide with those of the editors, the members of the Editorial Advisory Board or The Japan Foundation, Sydney.

Japanese names are written in first name-surname order, in accordance with English-language conventiōn. The long vowel sound in Japanese is indicated by a macron (e.g., kotsu), unless in common use without (e.g., Tokyo)

\section{PUBLISHED BY}

The Japan Foundation, Sydney

Level 4, Central Park

28 Broadway, Chippendale NSW 2008

www.jpf.org.au

July 2019

New Voices in Japanese Studies, Volume 11 is copyright (c) The Japan Foundation, Sydney and the authors. Copyright of the collection belongs to The Japan Foundation, Sydney. Copyright of the work belongs to the authors. All third-party images have been reproduced with permission where possible, and copyright remains with the original copyright holders.

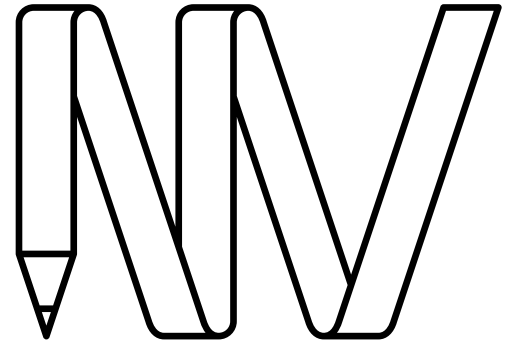

NEW

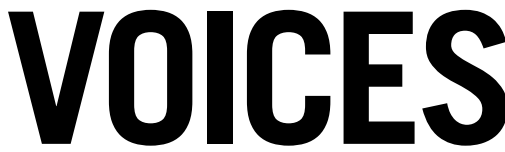

IN JAPANESE STUDIES

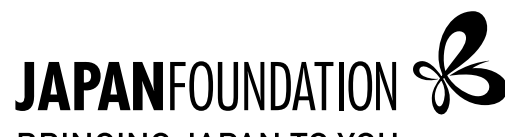

BRINGING JAPAN TO YOU

To link to this volume:

https://doi.org/10.21159/nvjs.11

ISSN 2205-3166

All articles can be downloaded free at newvoices.org.au

(C) The Japan Foundation, Sydney, 2019

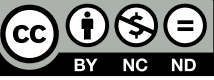

With the exception of images or other material identified as copyright of a third party, this content is licensed under the Creative Commons AttributionNonCommercial-NoDerivatives 4.0 International Licence. All other rights reserved. Permission requests for usages outside those governed by this licence should be directed to the Series Editor at newvoices@ijpf.org.au

We request attribution as follows: (C) The Japan Foundation, Sydney / [author name], [year of publication]. 


\section{Foreword}

\section{By Yoshihiro Wada}

Director, The Japan Foundation, Sydney

It is my great pleasure to introduce Volume 11 of New Voices in Japanese Studies. Since the journal's renewal in 2015, each new volume has brought with it at least one new development, and this volume is no exception. From this year, we are delighted to add reviews to the journal's publication remit. This opens up additional ways for early career scholars to engage in scholarly debate via the New Voices in Japanese Studies platform, which in turn can only further broaden the journal's readership. We are also incredibly pleased to announce that New Voices in Japanese Studies is now indexed by leading research database EBSCO Host, and we look forward to the increased discoverability this will offer the authors who publish with us.

Compared with Volume 10, which primarily featured the work of Honours students, this volume is distinct in that all authors are either $\mathrm{PhD}$ candidates or recent $\mathrm{PhD}$ graduates. Eligibility was only opened to $\mathrm{PhD}$ candidates from Volume 7 and to recent $\mathrm{PhD}$ graduates from Volume 8, so it is pleasing to see that the journal is indeed filling a niche in these areas. In terms of content, Volume 11 brings together work from a broad spectrum of disciplines, covering an equally broad spectrum of subject matter. The authors of the four main papers represent areas of study as diverse as environmental law, creative writing, media studies and civil society. Add the authors of the reviews-representing literature, religious studies and education policy—and the pool becomes broader still.

Despite this breadth, a close look at the featured papers reveals some surprising intersections. For example, while one paper examines how the Tokyo 2020 Olympic Games has become a source of tension for evacuees of the 3.11 disaster in Tohoku, another suggests that the omotenashi rhetoric that has emerged in relation to the Olympics has resulted in increasing levels of acceptance of Muslims in Japan. A third paper engages again with the 3.11 disaster, considering how social media use helped to generate a sense of community among Japanese people at the time. The themes of community and 3.11 also feature in the remaining paper, which looks at how Japan's environmental governance frameworks foster community involvement in wetland restoration, and argues that a "restoration ethos" underpins laws around post-3.11 recovery as well as environmental legislation. In this way, Volume 11 reflects the current state of Japanese Studies in our local region: broad in scope, yet fundamentally connected-often in fascinating ways. 
I would like to take this opportunity to extend my heartfelt thanks to the Guest Editor for this volume, Dr Emma Dalton of RMIT University. Editing these annual volumes, small as they may be, is no easy task. In balancing the timeintensive and sometimes unpredictable requirements of the journal with her day-to-day research and teaching loads, Emma has accomplished a remarkable feat, and we greatly appreciate the time, insight and expertise that she has so generously given to shape the papers in this volume. I also wish to thank this year's Editorial Board, who similarly gave of their time and expertise to provide valuable feedback on these and other papers. Finally, I wish to thank the Series Editor, Elicia O'Reilly, for her tireless efforts to further improve the journal each year and for bringing yet another volume to fruition.

Not all papers submitted to this volume have been published here. The editorial process can be difficult and time-consuming, requiring patience, vision and perseverance from both authors and editors alike. I congratulate the authors whose work is published in this volume. Equally, I encourage the authors whose submissions still require work not to be daunted, but to revise and resubmit, and I look forward to seeing their research published in a future volume.

In closing, whether you are a reader, author, reviewer, supervisor or editor of New Voices in Japanese Studies, we thank you for your interest in this volume and look forward to your continued support.

(July 2019) 


\section{Contents}

Foreword

$v \quad$ Introduction

Emma Dalton

\section{PAPERS}

1 Perceptions of Islam and Muslims in Contemporary Japan Atsushi Yamagata

Pepi Ronalds

47 Wetland Restoration in Japan: What's Law Got to Do with It? Evan Hamman

74 A Sense of Communal Belonging in Digital Space: The Case of the 3.11 Disaster

Sonja Petrovic

\section{REVIEWS}

99 The Evolution of English Language Learners in Japan: Crossing Japan, the West, and South East Asia (Yoko Kobayashi) Levi Durbidge

102 Japan: History and Culture from Classical to Cool (Nancy K. Stalker)

Gwyn McClelland

105 Diva Nation: Female Icons from Japanese Cultural History (Laura Miller and Rebecca Copeland, eds.)

Rebecca Hausler 


\author{
By Emma Dalton (RMIT University) \\ Guest Editor, New Voices in Japanese Studies, Volume 11
}

The 11th edition of New Voices in Japanese Studies began as journal editions often do: as a nebulous collection of submissions by scholars from a range of disciplines at varying stages of their research careers. Eventually, the final version has somewhat organically formed around the broad themes of national identity and Japan's position in the wider world since the Great East Japan Earthquake of 2011. Given the criticism sometimes levelled at the discipline of area studies as being excessively insular (a criticism that is arguably often justified in the field of Japanese Studies) this volume makes a welcome contribution to the field. Much has been made of Japan's soul-searching since the triple disaster of March 2011. The collection of papers in this edition from scholars from law, sociology, creative writing and media studies adds to this robust and shifting conversation.

Atsushi Yamagata's very readable article considers attitudes towards Muslim people in Japan. It provides intriguing insights into contemporary (mostly positive) attitudes towards Muslims, embedded in a fascinating history of Muslim presence in Japan. The world around Japan is experiencing the largest movement of people across borders ever seen-many of these people are those of the Muslim faith, escaping persecution or war. Against this backdrop, Japan's entrenched reticence to the idea of opening borders to refugees and other immigrants invites scrutiny, particularly as the country struggles with its own socio-demographic problems of a rapidly aging society and shrinking workforce. Yamagata's carefully considered analysis of media and existing survey results shows that Japanese society appears to be welcoming Muslims, which contrasts to high levels of Islamophobia seen elsewhere in the world. Yet, his paper suggests, this apparent welcome is extended with a caveat: Muslims, like many other immigrants to Japan, are expected to be temporary visitors rather than permanent additions to the Japanese populace.

Pepi Ronalds invites readers to consider the chasm between official government rhetoric of a hopeful, strong and unified nation preparing for the Tokyo 2020 Olympic Games and the material realities of those living in the Tohoku region-a region still in a process of recovery several years after it was struck by disaster. Drawing from interviews with those directly affected by the 2011 earthquake, tsunami and nuclear meltdown, Ronalds' paper critiques Japan's official message of hope, positivity and national cohesion expressed in glib Olympics propaganda and argues that victims of the 3.11 disaster feel removed from and alienated by these messages. The paper interrogates the 
justness of a discourse of the cult of the nation which diverts domestic and international attention and funds away from thousands of people whose lives remain fractured.

Evan Hamman's paper speaks to Japan's position in a rapidly changing and deteriorating socio-ecological world. The degradation of the natural environment is perhaps the most pressing issue of our time and we could be forgiven for regularly feeling an unsettling combination of impotence and panic upon hearing near-daily news reports pertaining to the planet's imminent demise as a result of seemingly unstoppable human behaviour. Hamman's paper about Japan's wetland restoration efforts explores an area not often talked about outside specialist circles, but an area of significance for what it reveals about the health of our natural environment. The paper considers the way that Japanese grassroots movements engage with both supra-national level and national level policies, and suggests that Japan's history of recovery from disasters combined with existing legal frameworks makes the country capable of leading the way in best practice wetland recovery.

Sonja Petrovic returns the readers' attention to the events and aftermath of 3.11 and explores the role that social media played in creating a sense of community for people from varying geographical locations, including different parts of Japan and those outside the country as well. Based on interviews and analysis of social media data, Petrovic argues that social media can be used to foster a sense of belonging amongst people regardless of temporal or spatial differences in post-disaster contexts, thus potentially becoming a tool that helps people to cope better in case of disasters.

NVJS11 is the first edition to feature book reviews. It was a bit of a risk, as is any new venture, and it appears to have paid off. The three reviews in this edition by Levi Durbidge, Gwyn McClelland and Rebecca Hausler critically engage with texts that appear relevant and useful for research as well as teaching. While book reviews are a lot of work, they are usually worth the effort for what one learns in the process. I encourage anyone thinking about submitting a review to NVJS to do so.

I am honoured and deeply grateful to have been offered the role of Guest Editor for this volume. I would like to extend my sincere thanks to The Japan Foundation, Sydney, and in particular to Director Yoshihiro Wada for this invaluable opportunity. This occasion has led to some fantastic and capacious learning moments. I have learned much from the editorial process itself and also about the work of emerging Japanese Studies scholars in Australia. Working with Series Editor Elicia O'Reilly has been a lesson it what it means to be professional, warm, funny and efficient all at the same time. Elicia has been wonderfully alert and responsive and her level-headedness was an excellent tonic to my diplomacy short-comings.

Finally, I thank the contributors and reviewers for their patience and hard work in this process. Several submissions did not make it into this edition, but I hope to see them again as published articles in the next edition. 


\section{Perceptions of Islam and Muslims in Contemporary Japan}

\author{
ATSUSHI YAMAGATA \\ The University of Wollongong
}

\section{ABSTRACT}

In Japan, the population of Muslim residents is estimated to be only around 170,000; however, the number of Muslims visiting or living in Japan is expected to increase in the future. There have been some studies to date focusing on the development of Muslim communities in Japan, but there has only been limited discussion of perceptions of Islam and Muslims in Japan. In this article, I explore perceptions of Islam and Muslims by analysing incidences of official surveillance of Muslims in Japan, displays of antiIslamic sentiment by ultra-conservative activists, and newspaper articles about Muslims in Japan. Following the recent influx of Muslim refugees into Europe, some European countries have experienced a rise in Islamophobia, while other countries have seen a rise in negative attitudes towards Muslims in the wake of terrorist incidents attributed to Islamic groups. Based on my analysis of media representations of Muslims in Japan, I consider how Islam and Muslims living in and coming to Japan are perceived, and explore the rationales behind these perceptions. In conclusion, I argue that Japan is showing a rising interest in Muslims as visitors or tourists, and that there is little evidence to indicate increasing negative attitudes towards them. In Japan's case, rather than inciting violence or hate speech, I contend that a recent rise of national pride in Japanese hospitality has encouraged Japanese people to be more welcoming to Muslims. I also provide an overview of the historical background and current situation of Muslims living in Japan to address the lack of English-language scholarship in this area.

\section{KEYWORDS}

contemporary; diaspora; history; human rights; Islam; Islamophobia; media; Muslims; national pride; omotenashi; perceptions; surveillance; xenophobia

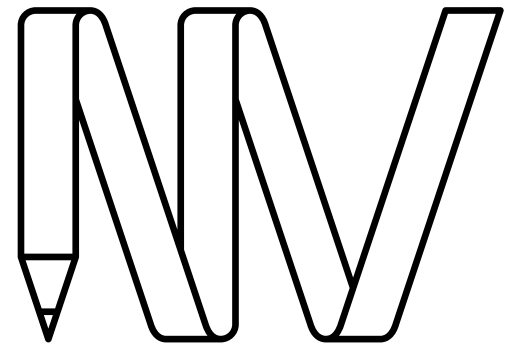

NEW

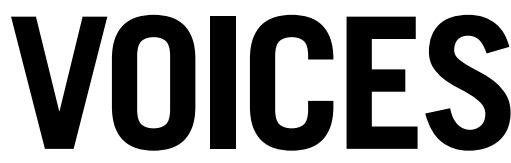

IN JAPANESE STUDIES

JAPANFOUNDATION \&

BRINGING JAPAN TO YOU

To link to this article:

https://doi.org/10.21159/nvjs.11.01

ISSN 2205-3166

New Voices in Japanese Studies is an interdisciplinary, peer-reviewed journal showcasing the work of emerging scholars with ties to Australia or New Zealand and research interests in Japan.

All articles can be downloaded free at newvoices.org.au

(C) The Japan Foundation, Sydney and Atsushi Yamagata, 2019

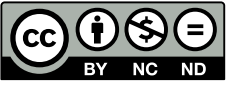

This work is licensed under a Creative Commons Attribution-NonCommercialNoDerivatives 4.0 International License. 


\section{INTRODUCTION}

As a result of ongoing conflict or persecution worldwide, many parts of the world have experienced an influx of unprecedented numbers of people seeking asylum. In recent years, waves of asylum seekers have fled violence and persecution in largely Muslim nations such as Syria, Iraq and Afghanistan, with many seeking refuge in Europe. ${ }^{1}$ In 2015 and 2016, the number of first-time asylum applications recorded in the EU member states exceeded 1.2 million (Eurostat 2018b). Under these circumstances, a rise in Islamophobia has been observed in the region. ${ }^{2}$ According to a survey conducted by Chatham House in 10 European states, an average of $55 \%$ of respondents, ranging from $71 \%$ in Poland to $41 \%$ in Spain, agreed that "all further immigration from mainly Muslim countries should be stopped" (Goodwin et al. 2017). In keeping with these attitudes, political parties which have xenophobic or anti-Islam tendencies have increased their influence in Europe (Bayrakli and Hafez 2018, 13-18). ${ }^{3}$

While perceptions of Islam and Muslims in Europe have been discussed by scholars amid the rise of Islamophobia, there has only been limited discussion of perceptions of Islam and Muslims in the East Asia region. In this article, I analyse media representations of Islam and Muslims in Japan. I also note incidences of police surveillance of Muslims in Japan and displays of anti-Islamic sentiment by ultra-conservative activists. Based on this, I explore how Islam and Muslims are perceived in Japan and the rationales behind these perceptions. There are no official statistics on the population of Muslims in Japan as the Japanese census does not include a question about religion. However, Tanada (2018b) estimates that around 170,000 Muslims were living in Japan as of the end of 2016. Given that the Japanese population was around 127 million as of February 2018 (Statistics Bureau 2018), we can estimate that Muslims constitute less than $0.2 \%$ of the Japanese population. It should be noted that even since the ongoing Syrian refugee crisis began in 2011, Japan's borders have been effectively closed to refugees so it has not experienced the same influx of Muslim asylum seekers seen in European countries over this time. ${ }^{4}$

The population of Muslims in Japan is small, but it is important to understand perceptions of Islam and Muslims in Japan for three reasons. First, the presence of Muslims in Japan is on the increase. As I discuss below, the

1 There is no official data about the religion of asylum seekers registered in the EU member states. However, given that more than half of all asylum seekers registered during this period were from the nations mentioned above, it can be supposed that the majority of them are Muslims (Eurostat 2018a).

2 The term 'Islamophobia' started to be widely used in public and academic debates in the late 1990s, especially after the publication of a report titled Islamophobia: A Challenge for Us All by the Runnymede Trust in 1997 (Conway 1997), but the definition of the term varies. This article follows Bleich's definition of Islamophobia as "indiscriminate negative attitudes or emotions directed at Islam or Muslims" (Bleich 2011, 1585).

3 In Austria, for example, the far-right Freedom Party entered government as a junior coalition partner with the People's Party after the national election in October 2017 (Nasralla and Murphy 2017).

4 In Syria, protests against President Bashar al-Assad and violent responses by his government in 2011 developed into a civil war, which has caused more than 360,000 deaths to date. As of February 2019, 5.7 million Syrians had fled the country as refugees and 6.2 million people were internally displaced (BBC 2019). While the Japanese government announced a plan in 2016 to accept 150 Syrians as exchange students in response to the crisis (Mie 2016), the number of Syrian people recognised as refugees in Japan was only 12 as of the end of 2017 (Wilson 2018). Although Japan acceded to the UN Refugee Convention 1981, it has been reluctant to accept refugees. In 2017, only 20 people were recognised as refugees although there were 19,629 asylum applications that year. Between 1982 and 2017, only 708 people (from 60,675 applications) have been recognised as refugees (Ministry of Justice 2018). For further discussion, see Yamagata (2017). 
population of Muslims in Japan has been increasing since the 1980s and, as a result, the number of mosques in Japan has also increased (Tanada 2015). In addition, the number of Muslim tourists visiting Japan is also on the increase (CrescentRating 2017, 9). Therefore, direct interaction between Muslims and non-Muslim Japanese is expected to increase. Given that the increase in the Muslim population has been associated with growing prejudice against them in Europe, it is of comparative interest to grasp how Muslims are perceived by Japanese people. Second, so-called 'hate speech' against non-Japanese in Japan has been identified as a serious social problem. Since around 2000, xenophobic discourses have emerged on the internet and, since the middle of the 2000s, ultra-conservative groups such as Kōdō-suru Hoshu Undō (行動する保守運動; 'Action Conservative Movement') have started to hold rallies verbally attacking foreign residents (Yamaguchi 2013). The targets of these movements are ethnic Korean or Chinese residents in most cases. Third, a rise in Islamophobia has been observed not only in Europe but also in East Asia. For example, Luqiu and Yang (2018) point out that negative stereotypes about Islam and Muslims are spreading among Chinese citizens. Furthermore, South Korea, whose Muslim population is only around 100,000 (Diaconu and Tacet 2017), has seen anti-Islamic discourses emerge with the arrival of Yemeni refugees to the island of Jeju in South Korea in 2018 (Park 2018). Taking these situations into account, understanding the perceptions of Islam and Muslims in Japan is an important first step toward identifying and addressing possible anti-Islam tensions in Japanese society.

Academic literature in this area includes some largely ethnographic studies of Muslims living in Japan which focus on Muslim lifestyles, businesses and religious activities (see Sakurai 2003; Higuchi et al. 2007; Tanada 2015). There is, however, room for more research on perceptions of Islam and Muslims in Japan. There are also some studies based on surveys which explore Japanese perceptions of Muslims (see Matsumoto 2006; Miura 2006; Tanada et al. 2014) and these studies are valuable, but they were conducted before the recent turmoil in the Middle East and the outbreak of the Syrian civil war in 2011 which caused today's world-wide refugee crisis. ${ }^{5}$ As such, it is possible that perceptions of Islam and Muslims in Japan might have changed since these studies were conducted.

While surveys are one way to understand the topic, there are other ways to grasp perceptions of Islam and Muslims in Japan, one of which is content analysis of media texts. As Turner (1997) states, "media texts offer especially rich opportunities to observe the cultural construction of meaning, [and are] locations where we can see the social production of ideas and values happening before our eyes" (326). In this study, I analyse articles from two Japanese newspapers: Yomiuri Shimbun and Asahi Shimbun. These are the largest newspapers in Japan by circulation, with more than eight million (Yomiuri) and six million subscribers (Asahi) to their respective morning editions (Yomiuri Shimbun 2018b; Asahi Shimbun 2018a). Yomiuri Shimbun is considered to be a conservative newspaper, while Asahi Shimbun is considered progressive (Akuto 1996, 319). I analyse articles from these 
two newspapers, including regional editions, that were published between 1 January 2014 and 30 June 2018. In 2014, asylum seekers arriving in Europe started to increase (Eurostat 2018b) and the so-called Islamic State declared the establishment of a caliphate, or state governed in accordance with Islamic law (BBC 2015). From around 2014, stories about Muslim refugees and atrocities committed by the Islamic State began to be covered by the Japanese media. I analyse the content of newspaper articles from this period and identify major themes in discussions about Islam and Muslims. While previous studies have mainly focused on the images Japanese people have of Islam and Muslims in general, I particularly focus my analysis on newspaper articles concerning Muslims living in or coming to Japan in order to see how recent stories of this nature have been covered, and to thereby gauge broader public sentiment. ${ }^{6}$

I start by looking at the historical background of Japan and Islam. There is little English-language scholarship on Muslims in Japan, so I consider it valuable to describe the historical background and the current situation of Muslims living in Japan first. I then review the aforementioned studies on Japanese perceptions of Islam and Muslims which are based on surveys. Next, I focus on the surveillance of Muslims by Japanese police and displays of anti-Islamic sentiment by ultra-conservative activists. I then analyse newspaper articles about Japan and Muslims in order to explore perceptions of Islam and Muslims in mainstream media, showing that Japan's interest in Muslims as visitors or tourists is on the increase. In the final section, I explore the rationales behind the perceptions of Islam and Muslims in contemporary Japan.

\section{MUSLIMS IN JAPAN: HISTORY AND CURRENT SITUATION}

Although some scholars point out that there has been interaction between Japan and the Muslim world from as far back as the eighth century (e.g., Komura 1988), it is from the end of the 19th century that communities of Muslims began to form in Japan. From the end of the 19th century, Indian merchants, most of whom were Muslims, started to reside in international port cities such as Yokohama and Kobe (Green 2013). From the 1920s, Tatar Muslims fleeing the Russian revolution migrated to Japan through Manchuria and Korea and formed communities in cities such as Tokyo, Nagoya, Kobe and Kumamoto (Matsunaga 2009, 3-9). ${ }^{7}$ Following the arrival of these Muslims, three mosques were established in Japan in the 1930s. In 1935, Kobe Mosque (Figure 1), which was the first mosque in Japan, was established, followed by Nagoya Mosque in 1936 and Tokyo Mosque in 1938 (Tanada 2015, 24). ${ }^{8}$ 


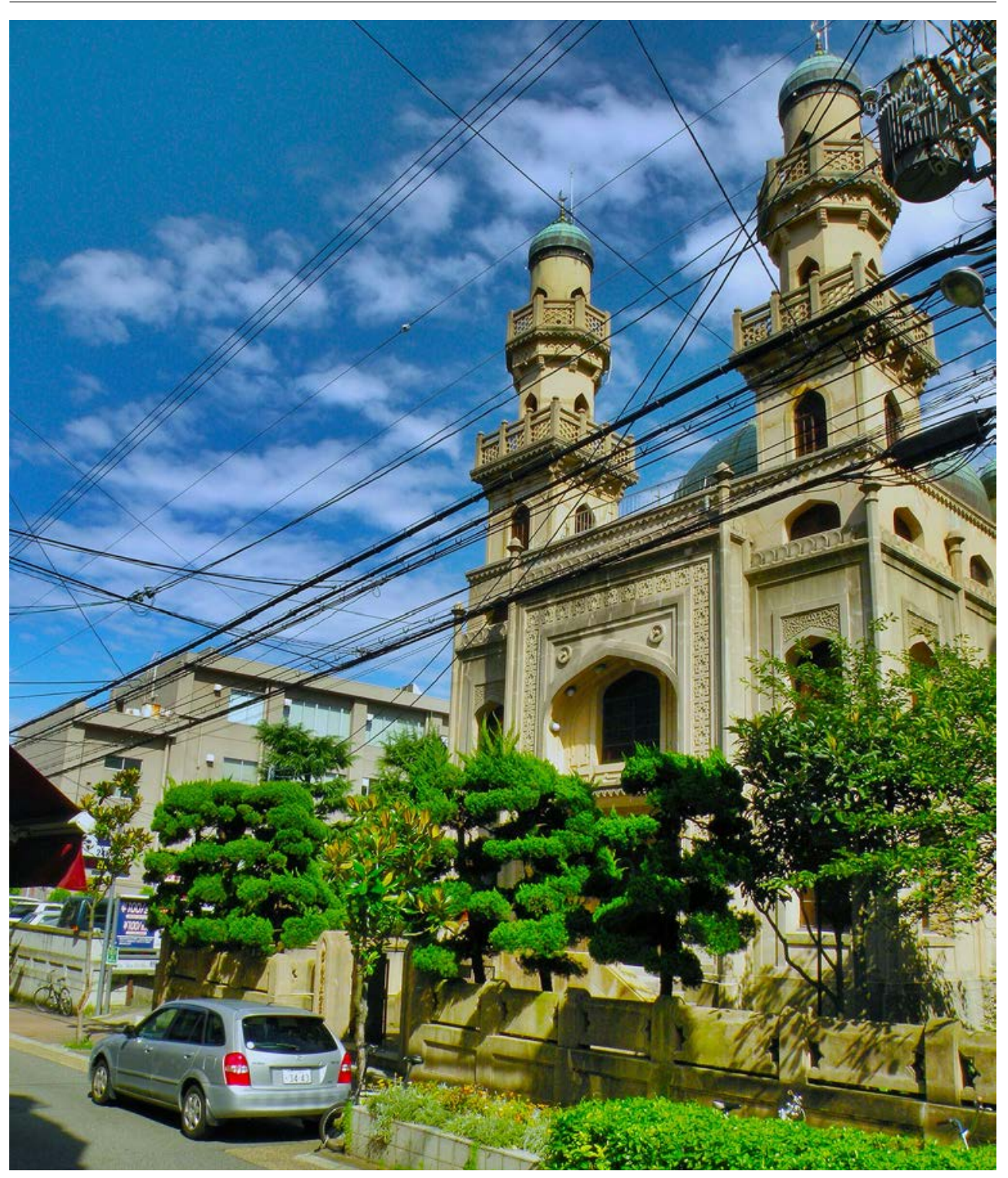

Figure 1: Kobe Mosque, 2010.

Source: Mosque in Japan by Lmadcap, via Flickr (public domain).

While the establishment of Kobe Mosque and Nagoya Mosque was initiated by Muslims, Tokyo Mosque was established in a different context: it was a part of the 'Kaikyō Seisaku' (回教政策; Islamic policy) of the Japanese government of the time (Tanada 2015, 24; Fukuda 2010), and was established with support not only from Japanese politicians but also from military officials (Esenbel 2004, 1157-67; Biygautane 2016, 121). The Japanese government, particularly after the invasion of Manchuria in 1931, had begun to seek cooperation with Muslims in its foreign policy with a view to making use of local Muslims in its advancement into North China and South East Asia, both of which had large Muslim populations at the time (Esenbel 2007, 263-64). To promote interaction between Japan and Muslims, some Islamic research institutes were also founded by the government under its Islamic policy (Tanada 2008, 216). One of these institutes, Dai-Nippon Kaikyō Kyōkai (大日本回 教協会; the Greater Japan Muslim League), implemented measures to raise awareness of Islam in Japan, such as publishing periodicals and holding exhibitions about Islam (Tanada 2013). There are no official statistics about the Muslim population in pre-1945 Japan, but Tanada posits that it did not exceed 1,000 between 1931 and 1945 even by the most generous estimation (Tanada 2015, 10).
NEW VOICES

IN JAPANESE STUDIES 
After the end of World War II, the Islamic research institutes were dissolved or banned by the Supreme Commander for the Allied Powers during the Allied occupation of Japan, as those institutes were regarded as part of Japan's military campaigns (Fathil and Fathil 2011, 132-33). In addition, most of the Tatar Muslims, who had been the largest group among the Muslim population of Japan, migrated to the US or Turkey as they were granted Turkish citizenship in 1953 (Tanada 2015, 10; Numata 2012, 132-34). ${ }^{9}$ As a result, the Muslim population in Japan in the 1950s is estimated to have dropped to only a few hundred (Tanada 2015, 10-11).

The number of Muslims in Japan remained quite small in the decades after the war, but has grown since the late 1980s. From the late 1980s to the beginning of the 1990s, Japan experienced a rapid increase in immigrant workers from countries like Pakistan, Bangladesh and Iran, where the majority of the population is Muslim. At that time, the Japanese economy was in its bubble phase and the yen was strong, so immigrant workers came to Japan to earn income for remittance back to their home countries. They were employed in factories or construction sites which were experiencing labour shortages (Sakurai 2003, 26). In the 1980s, Japan had Visa Waiver Agreements for tourists from Pakistan, Bangladesh and Iran. It was illegal for those on shortterm residency to work in Japan, but there were many people working without a valid visa or overstaying after their resident status had expired (Sakurai 2003, 26-29). Under these circumstances, at the beginning of the 1990s, it is estimated that the number of non-Japanese Muslims in Japan reached more than 100,000 (Tanada 2015, 14). However, as the number of undocumented foreign workers increased rapidly, the Japanese government suspended the Visa Waiver Agreements with Pakistan and Bangladesh in 1989 and with Iran in 1992. After this, the entry of people from those countries into Japan decreased rapidly and, as the Japanese government tightened control over undocumented immigrants, most of them went back to their countries of origin (Sakurai 2003, 40-42).

While the majority of Pakistani, Bangladeshi and Iranian people who came to Japan between the late 1980s and early 1990s left Japan, some obtained longterm resident status through marriage and remained (Higuchi 2007b, 16-19). Most of the Muslims who had come to Japan from those three countries were males in their 20s or 30s, and marriages between Muslim men and Japanese women increased around this time (Sakurai 2003, 28). According to Kojima (2006), among married men from these countries residing in Japan, around $80 \%$ of Pakistanis and Iranians and about $50 \%$ of Bangladeshis were married to Japanese women as of 2000 (124-26). Some of these men, especially Pakistanis, owned successful businesses in areas such as used car export and the food industry, and lived stable lives in Japan both legally and financially (Higuchi 2007a; Fukuda 2007). 
After the influx of Muslims from Pakistan, Bangladesh and Iran had ended, Muslims from Indonesia started to come to Japan from the 1990s as technical intern trainees or students. Numbers of Indonesian nurses and caregivers also increased from 2007, following Japan's signing of an Economic Partnership Agreement with Indonesia. ${ }^{10}$ Furthermore, as the Japanese government has been promoting a policy of increasing its international student intake, the number of Muslim students coming to Japan has also grown (Tanada 2015, 23). ${ }^{11}$ As a result of these initiatives, the number of non-Japanese Muslim residents in Japan has gradually increased over the past decade. Based on foreign resident statistics, Tanada estimates that the number of non-Japanese Muslims was around 100,000 in 2010 and that it had reached around 130,000 as of 2016. Of the 2016 total, Indonesian nationals comprised the largest group at around 33,000, followed by Pakistanis and Bangladeshis (Tanada 2018b, 111-13).

In addition to the growing number of non-Japanese Muslim residents in Japan, the number of Japanese Muslims is also growing due to intermarriage between non-Japanese Muslims and Japanese, and the children born to these families. ${ }^{12}$ Tanada estimates that there were around 40,000 Japanese Muslims living in Japan, in addition to Muslim foreign residents, as of 2016 (Tanada 2018b). Assuming this is correct, there were around 170,000 Muslims in total living in Japan at that time. Moreover, the increase in foreign tourism to Japan in recent years has seen a rapid increase in Muslim tourists. ${ }^{13}$ This has mainly been due to the introduction of visa-free tourist travel for Indonesians and Malaysians, the depreciation of the Japanese yen and the growth of lowcost air travel (CrescentRating 2017, 9). According to the Japan Muslim Travel Index compiled by CrescentRating in 2017, the number of Muslim tourists arriving in Japan was around 150,000 in 2004 but reached 700,000 in 2016, with 27\% from Indonesia, 23\% from Malaysia and 5\% from Singapore. ${ }^{14}$ At the time of writing, more than one million Muslim tourists were expected to visit Japan in 2018 (CrescentRating 2017, 7-10).

As the Muslim population in Japan has grown, the number of mosques in Japan has also increased. Until the late 1980s, there were only four mosques in Japan (Tanada 2015, 25). However, this number started to rise rapidly from the 1990s. According to Okai (2007), Muslim immigrant workers who came to Japan in the 1980s were working in industrial areas on the outskirts of big cities, so the demand for new mosques in those areas increased. In 1991, a group of local Muslims raised funds through donations and succeeded in founding a new mosque in Saitama prefecture by purchasing an existing building and renovating it (Okai 2007, 184-88). Since then, new mosques

10 Since 1997, Indonesians have made up the largest group among the non-Japanese Muslim population in Japan (Tanada 2015, 14).

11 In 1983, the Japanese government revealed a plan to increase international student numbers, with a goal of accepting 100,000 students. This goal was achieved in 2003. In 2008, it unveiled a new plan to accept 300,000 international students by 2020 (Ministry of Education, Culture, Sports, Science and Technology 2012). 12 Tanada (2018b) defines Japanese Muslims as Muslims who have Japanese nationality. Specifically, they include Japanese who have converted to Islam, children born to Muslims where at least one parent is Japanese, and foreign-born Muslims who came to Japan and naturalised as Japanese. In this article, I follow Tanada's definition.

13 The number of foreign tourists to Japan was around 10 million in 2013, but surpassed 30 million in 2018 (The Japan Times 2018).

14 CrescentRating is a Singapore-based organisation that is self-described as "the world's leading authority on halal-friendly travel” (CrescentRating 2018). The Japan Muslim Travel Index is one in a series of Muslim Travel Index reports produced by CrescentRating based on market research into halal tourism.

Atsushi Yamagata New Voices in Japanese Studies, Vol. 11, 2019, pp. 1-25 
have been established in many parts of Japan. Tanada (2015) identifies the increase in Muslims who own successful businesses and have settled in Japan as the main factor behind this (26-28). Tanada also notes that this spread was helped by the sharing of knowledge about founding mosques, which helped Muslim residents of Japan collect funds in a variety of ways from Muslims both in Japan and abroad $(2015,26-28)$. As of October 2017, the number of mosques in Japan had reached 102 (Tanada 2018a).

As noted above, direct interaction between non-Japanese Muslims and the Japanese started less than 150 years ago. Except for the short period in which Japan sought cooperation with Muslims for the purposes of imperial expansion, interaction with Muslims has historically been limited, although this is likely to change as the number of Muslims in Japan continues to grow. With this in mind, in the following section I explore contemporary perceptions of Islam and Muslims among Japanese people.

\section{HOW ARE ISLAM AND MUSLIMS PERCEIVED IN JAPAN?}

\section{Previous Studies on Japanese Perceptions of Islam and Muslims}

As the Muslim population has historically been small in Japan and direct interaction between Japanese people and Muslims has been relatively limited, perceptions of Islam and Muslims in Japan have received only limited scholarly attention to date. Even so, several studies on this topic have been conducted since the 2000s. Matsumoto (2006) carried out a survey on perceptions of Islam among high school students in 2003 and Miura (2006) carried out the same survey among university students in 2005. In one question, students were asked to choose words they associated with three religions: Islam, Christianity and Buddhism. Both the high school and university students associated more negative words with Islam than with Christianity and Buddhism, choosing such descriptors as "backward", "intolerant", "strange", "unfree" and "aggressive" to reflect their images of the religion (Miura 2006, 179-83). Both Matsumoto and Miura point out that the results were influenced by the Japanese mass media, which often covered Islam in the context of news about conflicts (Matsumoto 2006, 201-02; Miura 2006, 187-89).

Following these studies, between 2009 and 2012 the Institute for Multiethnic and Multi-generational Societies (IMEMGS) at Waseda University conducted surveys on residents living in areas near a mosque in three cities: Gifu City, Imizu City (in Toyama Prefecture) and Fukuoka City (Tanada et al. 2013; Tanada et al. 2014; Tanada and Okai 2011). An overview of the results shows that the respondents had negative images about Islam and Muslims in all three cities. While less than a quarter of residents agreed with positive opinions about Islam such as "advanced", "tolerant" and "peaceful", more than $60 \%$ of the respondents agreed with negative opinions such as "Islam is a radical religion" (Tanada et al. 2013, 78-88; Tanada et al. 2014, 69-78; Tanada and Okai 2011, 72-84). Reflecting this trend, the respondents were more reluctant to express approval about the admission of Muslims into 
Japan compared with the admission of foreigners in general. While around $30 \%$ of surveyed residents agreed with the admission of foreigners to Japan, less than 5\% agreed with the admission of Muslims in each of the three cities (Tanada et al. 2013, 54, 71; Tanada et al. 2014, 48, 63; Tanada and Okai 2011, 58, 87).

Regarding the rationales behind the negative images, Tanada again points to the influence of mass media, where Islam is often associated with terrorism (Tanada 2015, 84-85). In the surveys, more than half of the respondents indicated that the topics they most frequently heard about in connection with Islam were "conflicts and incidents" (Tanada et al. 2013, 75; Tanada et al. 2014, 66-67; Tanada and Okai 2011, 89). Furthermore, while the surveys were conducted in areas near mosques, around $90 \%$ of the respondents reported that they did not have any Muslim acquaintances (Tanada et al. 2013, 68; Tanada et al. 2014, 61; Tanada and Okai 2011, 84). Tanada (2015) argues that the respondents tended to have formed images about Islam and Muslims without actually interacting with Muslims, thereby indicating mass media influence as the most likely foundation underpinning these images (85).

In summary, these studies indicate that negative images about Islam and Muslims are shared by Japanese people (both student and non-student populations), and that these images appear to be fuelled by the mass media. These studies are valuable in that they investigated the perceptions of Islam among large numbers of Japanese people. However, the environment surrounding Japan and Muslims has been changing rapidly since these surveys were conducted, and the presence of Muslims in Japan-particularly as tourists-is on the increase. As a result, while Japanese media coverage of Islam may have focussed on news about conflicts at the time that these surveys were conducted, the focus of recent coverage has started to shift to Muslims living in or coming to Japan, as I discuss below.

\section{Surveillance of Muslims in Japan}

In this section I discuss the attitudes of the Japanese government, and particularly the Japanese police, toward Muslims living in Japan. Although there have been no terrorist attacks by Muslim extremists in Japan, Muslims living in Japan have been under official surveillance in the name of national security. In 2010, leakage of confidential documents on the internet from the Tokyo Metropolitan Police Department revealed that police had profiled around 72,000 Muslims from countries of the Organisation of Islamic Cooperation (OIC) living in Japan, including children, and had carried out surveillance of places where Muslims gather, such as mosques, shops and businesses (Attorney Team for Victims of Illegal Investigation against Muslims 2014). ${ }^{15}$ Seventeen of the Muslims whose personal information was included in the leaked documents filed a lawsuit against the national government and the Tokyo metropolitan government claiming that the surveillance was illegal and violated their "rights to privacy, equality and freedom of religion" (Blakkarly 2016). While the Tokyo District Court 
ordered compensation of 90 million yen for violating the complainants' right to privacy, it judged the surveillance operations to be "necessary and inevitable measures" (Blakkarly 2016). The plaintiffs appealed to higher Courts, but the Tokyo High Court upheld the ruling and, on 31 May 2016, the Supreme Court dismissed their final appeal, judging that the surveillance was not unconstitutional (Asia-Pacific Journal Report 2016). ${ }^{16}$

The same view was expressed by delegates of the Japanese government at a hearing of the Committee on the Elimination of Racial Discrimination in the United Nations in 2014. Asked about the systematic surveillance of Muslims in Japan, a delegate stated that police were carrying out the surveillance not because of their religion but to uphold public security. Another delegate from the National Police Agency stated that the police were investigating in a lawful way (Office of the United Nations High Commissioner for Human Rights 2014). In short, both the courts and the Japanese government approved of the surveillance of Muslims living in Japan, insisting that it was necessary as a counter-terrorism measure and that it was not based on religious discrimination, but rather on public security policy.

However, the leaked documents indicate otherwise: they reveal that police collected the personal information of 72,000 people for the sole reason that they were from OIC countries, and therefore likely to be Muslim. In addition, the police encouraged their officers to gather information about Muslims from non-OIC countries, again including children, regardless of whether they had any record of wrongdoing (Attorney Team for Victims of Illegal Investigation against Muslims 2014). Given these facts, it can be considered that the Japanese government sees Muslims as potential terrorism suspects. While the concerns shared by people in authority are not necessarily representative of mainstream Japanese society, media reports of such surveillance may reinforce in the public mind an association between Islam and terrorism, even though there have been no terrorist incidents perpetrated by Muslims in Japan.

\section{Displays of Anti-Islamic Sentiment in Xenophobic Movements in Japan}

Islamophobia has not been explicit in Japan, but the rise of xenophobic movements by ultra-conservative groups in Japan since the 2000s has been identified in academic literature (Yamaguchi 2013; Shibuichi 2015). While these movements mainly target ethnic Koreans or Chinese, one group named Han Gurōbarizumu Kokusai Hoshu Rengō, or Anti-Globalism International Conservative Alliance（反グローバリズム国際保守連合; hereafter, AICA), started to target Muslims from around 2014. According to its website, the AICA is an anti-globalism organisation for which "anti-globalism" means "anti-European Union" (Han Gurōbarizumu n.d.). This does not mean that the AICA is anti-EU member states, but rather that it objects to the policies implemented in the EU, especially those which allow freedom of movement across state borders. The AICA website says, "the ugly situation in the EU 
caused by the Schengen Agreement and the monetary union should not happen in East Asia including Japan." 17 The protection of Japan's borders might be a common argument for conservative groups, but what is different about this group is that it is specifically against the admission of Muslims to Japan and regularly holds rallies in Tokyo verbally attacking Muslims.

The AICA has articles on its website and uploads videos of its rallies on the popular Japanese video-sharing website Niconico (ニコニコ動画), so we can understand its members' sentiments from these sources. The sources show that the AICA considers that there are two groups of Muslims: secular (世俗 派) and fundamentalist (稂格派). According to the AICA, most Muslims living in Japan in the past were secular Muslims who adapted to Japanese culture; however, its members' perceive fundamentalist Muslims to have increased in Japan over the last decade. Further, they believe that fundamentalist Muslims enforce Islamic (Sharia) Law wherever they live, and that this causes conflict in host societies. That is what is already happening in Europe, they argue. To prevent conflict or terrorism in Japan, they strongly object to the acceptance of Muslims (Endoshuichi 2015a, 2015b; Han Gurōbarizumu 2018).

The main targets of xenophobic movements in Japan are still Korean and Chinese residents, but it is notable that a group which also attacks Muslims has emerged. Considering that groups like the AICA often cite problems allegedly caused by Muslims in Europe, it can be argued that these groups see the influx of refugees to Europe and terrorist attacks in European cities as a threat to Japan.

\section{The Toshiko Hasumi Manga Incident}

In the middle of 2015, a controversial event occurred in Japan which, while not directly targeted at Muslims, can be seen as related to perceptions of Muslims through its link to the Syrian refugee crisis. ${ }^{18}$ On 9 September 2015, Japanese cartoonist Toshiko Hasumi posted an illustration of a girl to her official Facebook page (Hasumi 2015b)..$^{19}$ The illustration closely resembled a photograph of a Syrian girl at a refugee camp in Lebanon which was taken by Canadian photographer Jonathan Hyams (Osaki 2015b). In the illustration, the girl has a wry smile and a caption in the background says,

I want to live a safe and clean life, have a gourmet meal, go out freely, wear pretty things and luxuriate. I want to live my life the way I want without a care in the world-all at the expense of someone else. I have an idea. Why don't I become a refugee [Sōda nanmin shiyō]?20

(Hasumi 2015b)

17「シェンゲン協定や通貨統合によるEUの酷い現状を、日本を含むアジア地域に再現してはならない。」

The Schengen Agreement is the basis for the Schengen Area, which allows people in the EU to cross state borders without being subjected to border checks. It has been implemented since 1995 and now encompasses most EU states (European Commission 2018).

18 For a discussion of this incident in the context of Japan's response to the Syrian refugee crisis, see Yamagata (2017).

19 Although Hasumi's original post on Facebook has been removed, the illustration can be viewed online via the Wayback Machine digital archive. See the references list for details. The original photograph by Jonathan Hyams can be viewed in a Twitter post by Save the Children NZ (Hyams 2014).

20 「安全に暮らしたい 清潔な暮らしを送りたい 美味しいものが食べたい 自由に遊びに行きたい おしゃ れがしたい 贅沢がしたい 何の苦労もなく 生きたいようにいきていきたい 他人の金で。そうだ難民しよ 
Asked about the illustration by The Japan Times, Hasumi said it was her "understanding" that most of the people fleeing Syria this time were "bogus" asylum seekers or "illegal migrants" (Osaki 2015c). Some people outraged by this launched an online petition calling for Facebook Japan to recognise the illustration as an example of racism, but Facebook Japan responded that the illustration did not breach its guidelines, declining to delete it (Osaki 2015c). In the end, however, Hasumi removed the illustration herself. She stated that it was true that her illustration had caused trouble to the Canadian photographer who took the original photo while denying the claim that her illustration was racist (Osaki 2015b). A few months after this incident, Hasumi announced that she would publish a new book titled with the words from the illustration: Sōda nanmin shiyō-Hasumi Toshiko no sekai [そうだ難民しよう! はすみとしこの世界; ‘Why Don’t I Become a Refugee?—The World of Hasumi Toshiko'] (Hasumi 2015a). The work consists of her illustrations of Koreans, refugees and progressive politicians or activists. Anti-racist campaigners criticised the publication, saying that her illustrations were racist cartoons (Osaki 2015a). On the cover of the book, the controversial illustration of the Syrian girl was displayed, with her appearance changed from the original so that she no longer bore a close resemblance to the girl in Hyams' photo.

It should be noted that in Hasumi's book, anti-refugee sentiment is portrayed in the same context as anti-Korean sentiment. The title of the book may be Sōda nanmin shiyō ('Why don't I become a refugee?'), but approximately half of the illustrations in her book target Koreans. Similarly, the AICA-the Japanese ultra-conservative group which recently began targeting Muslimshas also attacked Koreans in its rallies. What we can see from these cases is that xenophobic movements which have attacked Koreans over the past decades have now begun to display anti-refugee or anti-Muslim sentiments in the wake of the refugee crisis and terrorist attacks in Europe. Despite there being no record of terrorist incidents committed by Muslims in Japan, what is happening in Europe seems to be felt as a threat to Japan by some groups. The trajectories of ultra-conservative activists such as Hasumi and the AICA can be viewed as providing potential ground for new xenophobic movements in Japan in the future.

\section{Perceptions of Islam and Muslims in Japanese Newspapers}

In this section I explore perceptions of Islam and Muslims in mainstream Japanese society by focusing on articles from two Japanese newspapers, Yomiuri Shimbun and Asahi Shimbun. I found 128 articles in Yomiuri Shimbun and 189 articles in Asahi Shimbun, including op-eds, feature articles and readers' letters, related to Muslims living in or coming to Japan which were published between January 2014 and June 2018. During this period, by far the most covered topic about Muslims in Japan was the need to provide better hospitality for Muslims through the establishment of prayer rooms and the provision of halal food, among other measures. Halal is an Arabic word meaning 'lawful' or 'permitted'; halal food is food which fits the dietary standards prescribed in the Quran, avoiding ingredients such as alcohol or pork that Muslims are forbidden to consume (Islamic Council of Victoria 
n.d.). Upon analysis, 87 articles in Yomiuri Shimbun (68\% of the Yomiuri total) and 96 articles in Asahi Shimbun (51\% of the Asahi total) addressed this topic (for a breakdown of coverage by topic and masthead, see Graph 1). ${ }^{21}$ These articles represent a total of $58 \%$ of the combined coverage studied.

Graph 1: Articles by Topic

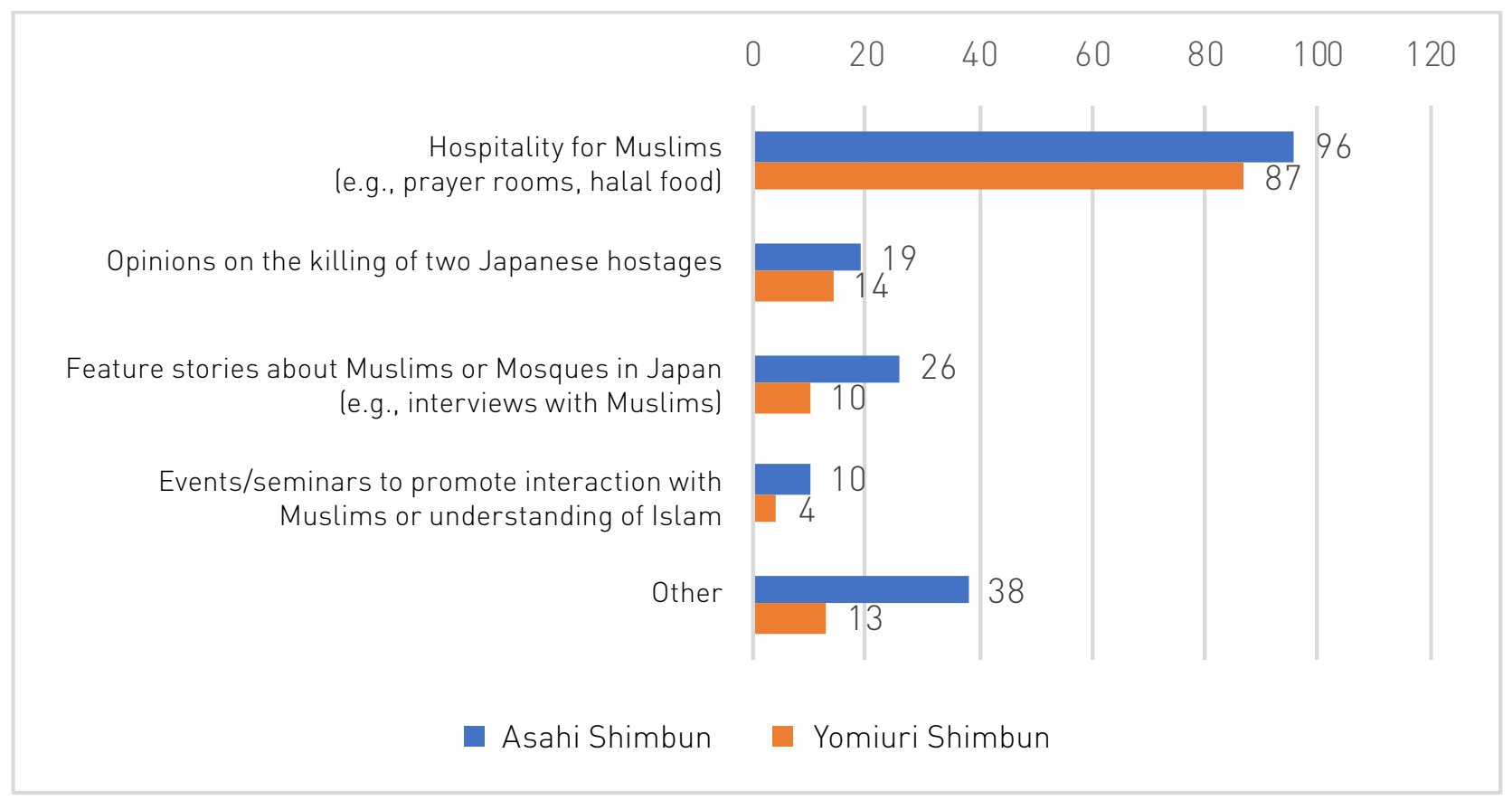

Sources: Asahi Shimbun and Yomiuri Shimbun between 1 January 2014 and 30 June 2018. Note: Articles which mention several topics about Muslims in Japan are classified based on the most prominent topic in each article.

In particular, the provision of halal food for Muslim tourists or students by Japanese businesses or universities was discussed in many articles (e.g., Asahi Shimbun 2014b, 2016a; Yomiuri Shimbun 2016c). A limited market for halal food has historically existed in Japan to serve the small number of Muslims living there. However, as the number of Muslim tourists has increased, interest in halal food has grown in Japan, particularly within the tourism industry (Tanada 2015, 94-96). To prove to their Muslim customers that their products are halal, more and more Japanese businesses have been seeking halal certification and Japanese organisations which issue halal certification have recently emerged (Henderson 2016). Several Yomiuri Shimbun and Asahi Shimbun articles reported on Japanese businesses that had obtained halal certification to attract more Muslim tourists (e.g., Asahi Shimbun 2016c, 2018b; Yomiuri Shimbun 2018a).

Efforts to attract Muslim tourists are not limited to the private sector. In May 2018, the 'Action Plan for Muslim Tourists in Japan’ [訪日ムスリム旅行者 対応のためのアクション・プラン] was formulated at the 20th Tourism Strategy Promotion Task Force meeting held by relevant ministries and agencies (Tourism Strategy Promotion Task Force 2018; Japan Tourism Agency 2018). The Action Plan stipulates specific measures to attract more Muslim tourists, 
such as the provision of halal food, the establishment of prayer rooms, and promotional activities in Muslim majority countries (Tourism Strategy Promotion Task Force 2018). The Japan Tourism Agency (under the Ministry of Land, Infrastructure, Transport and Tourism) also publishes guidebooks teaching Japanese people how to extend culturally appropriate hospitality to Muslims (Japan Tourism Agency 2018). At the municipal level, Kyoto City, cooperating with Kyoto Convention and Visitors Bureau, launched a website for Muslims named "Muslim Friendly Kyoto" in 2014 (Asahi Shimbun 2014a). The website provides information about prayer rooms, restaurants serving halal food and Muslim-friendly accommodation in Kyoto (Kyoto Convention and Visitors Bureau n.d.). Following the increase in Muslims visiting Japan, Japan's interest in Muslims as potential visitors or tourists also seems to be rising.

While hospitality for Muslims was the most commonly featured topic about Muslims in Japan during the period of my analysis, there were two incidents during that period which could conceivably have affected attitudes toward Muslims in Japan in a negative way. The first occurred in January 2015, when two Japanese citizens were taken hostage and later killed by the so-called Islamic State in the Middle East (Nordland 2015). This incident was widely covered in the Japanese media and was received with deep sorrow in Japan (Miura 2015). At the time, there was concern among Muslims in Japan about the possible rise of anti-Muslim sentiment (Asahi Shimbun 2015a). However, most articles which connected this incident with Muslims in Japan were about strong criticism of Islamic State from Muslims rather than reports about hatred against Muslims. From the time of the incident until the end of the following month, 14 articles in Yomiuri Shimbun and 19 articles in Asahi Shimbun reported the voices of Muslims in Japan criticising the actions of the Islamic State (e.g., Asahi Shimbun 2015c; Yomiuri Shimbun 2015). An article in Asahi Shimbun, published just after the Islamic State announced that they had taken the two Japanese hostages, reported that a sermon about the dignity of life had been delivered in the Tokyo Camii and that Muslims had prayed for the safety of the two Japanese hostages (Asahi Shimbun 2015d).

The second incident occurred in July 2016, when seven Japanese citizens were killed in Bangladesh, with responsibility claimed by Islamic State (BBC 2016). After this incident, one Yomiuri Shimbun article reported that a mosque in Shizuoka prefecture had received four threatening letters saying "both the Islamic State and you are Islam" and "I will hit you with a bat from behind" (Yomiuri Shimbun 2016b). ${ }^{22}$ The influence of these incidents, however, seems to have been limited. According to a book by Ken'ei Satō (2015), Muslims in Japan reported that they had not felt any change in Japanese people's attitudes toward them following the incident of the Japanese hostages. Further, the number of non-Muslim Japanese visiting the Tokyo Camii reportedly increased after the incident, which appeared to motivate Japanese people to learn about Islam (Asahi Shimbun 2015b; Satō 2015, 225). ${ }^{23}$ Efforts by Muslims to interact with Japanese society were also highlighted in media coverage from around this time. Both newspapers reported that a mosque in 
Chiba had established an anti-crime patrol team in cooperation with local residents and police (Yomiuri Shimbun 2016a; Asahi Shimbun 2016b).

In short, in mainstream news coverage in Japan from 2014 to the first half of 2018, Muslims were predominantly represented as potential visitors or tourists in a hospitality context. Although there were tragic incidents perpetrated by Islamic extremists which affected Japanese nationals during this time, the two Japanese newspapers studied highlighted the voices of Muslims criticising the atrocities, and there was little reporting of a rise in Islamophobia.

\section{RATIONALES BEHIND THE PERCEPTIONS OF ISLAM AND MUSLIMS IN CONTEMPORARY JAPAN}

In this section I explore the rationales behind the perceptions of Islam and Muslims in contemporary Japan. Previous studies based on surveys (discussed above) have revealed negative images of Islam and Muslims among some Japanese people, and have attributed this to media coverage of conflict or terrorism involving Islam and Muslims. However, my analysis of mainstream Japanese newspaper articles found that Muslims have been most frequently positioned as potential visitors or tourists in recent local coverage. Recent measures by national and municipal governments to attract Muslim tourists reflect this trend.

While the main reason behind the rise of interest in Muslims as visitors appears to be the rapid increase in Muslim tourists over recent years, I consider that this has been further fuelled by the so-called omotenashi ( もてなし; 'hospitality') boom which emerged after Tokyo won its bid to host the 2020 Olympic Games. At the 125th Session of the International Olympic Committee in Buenos Aires in September 2013, Japanese TV announcer Christel Takigawa made a speech in which she introduced omotenashi as "a spirit of selfless hospitality" (Takigawa 2013, 26'00"). Since then, the word omotenashi started to be used widely in Japan and has been framed by the media as a source of national pride (Brasor 2015). Among the articles collected for this study, the term 'omotenashi' was used in 31 Asahi Shimbun articles and 13 Yomiuri Shimbun articles. In addition, the title of a guidebook published by the Japan Tourism Agency aimed at stakeholders in the domestic tourism industry is Musurimu omotenashi gaido bukku [ムスリムおもてなしガイドブック; 'Hospitality Guidebook for Muslims'] (Japan Tourism Agency 2018 [2015]). The fact that this government agency has used the word 'omotenashi' in an official publication indicates how much the usage of this word has spread in Japan. I contend that this omotenashi boom has stimulated Japanese people's national pride in their hospitality, which has further accelerated the provision of halal food and the establishment of prayer rooms for Muslims. In other words, in Japan's case, rather than inciting violence or hate speech, the rise of discourses of omotenashi as a perceived national value has encouraged Japanese people to be more welcoming as more Muslims arrive as tourists. 
While this can be interpreted as a positive trend, it should be noted that this welcoming attitude promoted by the rise of national pride is largely directed at Muslims staying temporarily in Japan. The image of omotenashi is one of hosts receiving guests warmly; to this end, omotenashi toward Muslims means welcoming Muslims as guests-namely, as visitors or tourists. Given that the numbers of long-term Muslim residents and Japanese Muslims are growing, the Japanese interest in Muslims as tourists or visitors could have a potentially negative aspect to it. Recognising Muslims as visitors or tourists may reinforce the idea that Muslims are from outside of Japanese society, and lead to neglect of the existence of Muslim residents within Japanese society.

Lastly, I would like to consider why anti-Muslim discourse has not appeared in mainstream Japanese newspapers, even following occasions of atrocities committed by Islamic extremists. I consider that one of the main reasons is because the growing presence of Muslims in Japan has made it easier for Muslims to organise and communicate with Japanese society as a community. When incidents were perpetrated against Japanese nationals by Islamic State, newspaper sections devoted to local news introduced voices from local mosques (e.g., Yomiuri Shimbun 2015). Mosques have been established in many parts of Japan, providing platforms for Muslims to lend their voices to Japanese media and society. Muslims can also interact with non-Muslim Japanese residents through their mosques, as we can see from the abovementioned anti-crime patrol team in Chiba prefecture. As a result of these intertwining forces, the increase in Muslim tourists in Japan and the growing presence of Muslim residents in Japan can be said to have had a positive influence on perceptions of Islam and Muslims in Japan.

\section{CONCLUSION}

In this article, I have explored how Japanese people have perceived Islam or Muslims in recent years. Unlike previous studies, which have described negative images about Islam and Muslims held by Japanese people, my content analysis of recent coverage from mainstream Japanese newspapers indicates that interest in Muslims as potential visitors or tourists is rising in line with the recent increase in Muslim tourists to Japan. Furthermore, even when Japanese citizens have been victimised in atrocities committed by Islamic extremists, voices of Muslims criticising these incidents have been highlighted in Japanese newspapers in related media coverage. My analysis in this article shows that the increase in Muslim tourists has influenced perceptions of Islam and Muslims in contemporary Japan in a positive way.

As we have seen, however, the large numbers of Muslim refugees entering Europe have been perceived as a threat to Japan by some ultra-conservative activists, which has caused some anti-Muslim discourse. While anti-Muslim sentiment is relatively uncommon among Japanese people at the time of writing, this could change if an incident were to happen in Japan that was interpreted as a threat from Muslims. Furthermore, as noted above, the rising interest in Muslims as visitors or tourists may distract non-Muslim Japanese from paying attention to Muslim residents within Japanese 
society. Given that the presence of Muslims is increasing in Japan, further study of Muslims (including Japanese Muslims) and how they are perceived by non-Muslim Japanese is needed.

\section{GLOSSARY}

AICA

Anti-Globalism International Conservative Alliance, or Han Gurōbarizumu Kokusai Hoshu Rengō (反グローバリズム国際保守連合); a Japanese ultra-conservative group which started targeting Muslims from around 2014. They object to policies implemented in the EU, especially those which allow freedom of movement across state borders.

\section{Kaikyō (回教)}

An archaic term formerly used in Japan to mean Islam

\section{Kaikyō Seisaku (回教政策)}

Islamic policy; a policy enacted by the Japanese government, particularly after the invasion of Manchuria in 1931, which promoted cooperation with Muslims with a view to furthering Japan's expansionist agenda at the time.

\section{Halal}

An Arabic word meaning 'lawful' or 'permitted'. Halal food is food which fits the dietary standards prescribed in the Quran, avoiding ingredients such as alcohol and pork that Muslims are forbidden to consume.

\section{Islamic State}

An Islamic extremist group based in parts of Iraq and Syria. Islamic State drew international attention when it seized large territories in Iraq and Syria in 2014 and declared the establishment of a state governed in accordance with Islamic law.

\section{Kōdō-suru Hoshu Undō (行動する保守運動)}

'Action Conservative Movement'; a movement of ultra-conservative groups which hold rallies verbally attacking foreign residents, especially ethnic Korean or Chinese residents of Japan. The movement emerged in the middle of the 2000s.

\section{Omotenashi (おもてなし)}

'Hospitality'; this term began to be widely used in Japan following the success of Japan's bid to host the 2020 Olympic Games.

Organisation of Islamic Cooperation (OIC)

Formerly 'Organisation of the Islamic Conference'; an inter-governmental organisation with 57 member states which represents the Muslim world. Member states are spread over four continents and include Indonesia, Pakistan and Bangladesh, which are the top three countries of origin among non-Japanese Muslims living in Japan. 


\section{REFERENCES}

Akuto, H. 1996. "Media in Electoral Campaigning in Japan and the United States." In Media and Politics in Japan, edited by S. J. Pharr and E. S. Krauss, 31338. Honolulu: University of Hawai'i Press.

Asahi Shimbun [朝日新聞]. 2014a. “Isuramu kyōto-han, okoshiyasu [イスラム教徒は ん、おこしやす].” Asahi Shimbun (Morning edition, Kyoto), 15 January. p. 26.

2014b. “Musurimu gakusei ni mo oishī gakushoku [ムスリム学生にもおいしい 学食].” Asahi Shimbun (Morning edition, Shizuoka), 30 January. p. 33.

2015a. "Hi de satsugai, oshie ni hansuru: Nikushimi no rensa sakeyō [火で殺 害、教えに反する 増しみの連鎖避けよう].” Asahi Shimbun (Evening edition, Osaka), 4 February. p. 8.

2015b. “Isuramu o shiru, watashi no me to mimi de [イスラムを知る、私の目と 耳で.” Asahi Shimbun (Morning edition, Tokyo), 23 March. p. 37.

2015c. “Isuramu, imi wa heiwa [イスラム、意味は平和].” Asahi Shimbun, (Morning edition, Nagoya), 27 January. p. 32.

2015d. “Tonai mosuku, futari no kaihō inoru [都内モスク、2人の解放祈る].” Asahi Shimbun (Evening edition, Tokyo), 23 January. p. 17.

. 2016a. "Harāru ryōri Sapporo de kakudai [ハラール料理、札幌で拡大]." Asahi Shimbun (Morning edition, Hokkaido), 13 January. p. 28.

2016b. “Mosuku ga bōhan mimawaritai [モスクが防犯見回り隊].” Asahi Shimbun (Evening edition, Tokyo), 26 September. p. 10.

. 2016c. "Musurimu no kokoro tsukame: Hararu ninshō, ryōri ya shokuhin zokuzoku [ムスリムの心つかめ 八ラル認証、料理や食品続々].” Asahi Shimbun (Morning edition, Hiroshima), 22 September. p. 28.

2018a. "Company Overview 2018," Asahi Shimbun. Accessed 11 September, 2018. http://www.asahi.com/shimbun/company/csr/eng_overview2018.pdf.

. 2018b. “Rainichi Musurimu ni anshin wagashi [来日ムスリムに安心和菓子].” Asahi Shimbun (Morning edition, Hokkaido), 21 February, p. 30.

Asia-Pacific Journal Report. 2016. "Spying on Muslims in Tokyo and New York'Necessary and Unavoidable'?" The Asia-Pacific Journal: Japan Focus 14 (18), no. 2. https://apjjf.org/2016/18/APJ.html.

Attorney Team for Victims of Illegal Investigation against Muslims. 2014. "Extensive and Systematic Surveillance and Profiling of Muslims: Japan's Violation of the International Convention on the Elimination of All Forms of Racial Discrimination." Accessed 10 October, 2018. https://tbinternet. ohchr.org/Treaties/CERD/Shared\%20Documents/JPN/INT_CERD_ NGO_JPN_17783_E.pdf. 
Bayrakli, E., and F. Hafez. 2018. "The State of Islamophobia in Europe." In European Islamophobia Report 2017, edited by E. Bayrakli and F. Hafez, 7-31. Ankara: SETA. Accessed 28 April, 2018. http://www.islamophobiaeurope. com/wp-content/uploads/2018/04/EIR_2017.pdf.

BBC News. 2015. "What is 'Islamic State'?” BBC News, 2 December. Accessed 24 September, 2018. https://www.bbc.com/news/world-middle-east-29052144.

.2016. "Bangladesh Siege: Twenty Killed at Holey Artisan Bakery in Dhaka." BBC News, 2 July. Accessed 20 September, 2018. https://www.bbc.com/ news/world-asia-36692613.

. 2019. "Why is There a War in Syria?" BBC News, 25 February. Accessed 30 May, 2019. https://www.bbc.com/news/world-middle-east-35806229.

Biygautane, M. 2016. "Immigration and Religion: Muslim Immigrants in JapanTheir History, Demographics, and Challenges.” In Japan's Demographic Revival: Rethinking Migration, Identity And Sociocultural Norms, edited by S. R. Nagy, 113-44. New Jersey: World Scientific. https://doi.org/10.1142/ 9789814678889_0006.

Blakkarly, J. 2016. "Shadow of Surveillance Looms over Japan's Muslims." The Japan Times, 13 July. Accessed 10 September, 2018. https://www.japantimes. co.jp/community/2016/07/13/issues/shadow-surveillance-looms-japansmuslims/.

Bleich, E. 2011. "What is Islamophobia and How Much is There? Theorizing and Measuring an Emerging Comparative Concept." American Behavioral Scientist 55 (12): 1581-600. https://doi.org/10.1177/0002764211409387.

Brasor, P. 2015. “'Omotenashi' Comes Up Short on Humility." The Japan Times, 10 October. Accessed 14 January, 2019. https://www.japantimes.co.jp/ news/2015/10/10/national/media-national/omotenashi-comes-shorthumility/.

Conway, G. 1997. Islamophobia: A Challenge for us All. London: Runnymede Trust.

CrescentRating. 2017. Japan Muslim Travel Index (JMTI) 2017. Accessed 24 September, 2018. https://www.crescentrating.com/reports/japan-muslimtravel-index-2017.html.

CrescentRating. 2018. “About Us," CrescentRating. Accessed 24 September, 2018. https://www.crescentrating.com/about-us.html.

Diaconu, R., and A. Tacet. 2017. "The Muslims of South Korea." Al Jazeera, 15 November. Accessed 16 August, 2018. https://www.aljazeera.com/ indepth/inpictures/2017/11/muslims-south-korea-171114104611451.html.

Endoshuichi. 2015a. "Heisei nijūnana-nen jūichi-gatsu nijūroku-nichi Shinjuku-gai senkokuchi [平成二十七年十一月二十六日新宿街宣告知]. Han Gurōbarizumu Kokusai Hoshu Rengō [反グローバリズム国際保守連合], blog post, 25 November. Accessed 11 September, 2018.http://anti-globalism.org/?p=1284. 
.2015b. “Isuramufobia to kokunai no genjō [イスラムフォビアと国内の現状].” Han Gurōbarizumu Kokusai Hoshu Rengō [反グローバリズム国際保守連合], blog post, 6 March. Accessed 11 September, 2018. http://anti-globalism. $\operatorname{org} / \mathrm{p}=1193$.

Esenbel, S. 2004. “Japan's Global Claim to Asia and the World of Islam: Transnational Nationalism and World Power, 1900-1945." The American Historical Review 109 (4): 1140-170. https://doi.org/10.1086/530752.

. 2007. "The Legacy of The War And The World of Islam In Japanese PanAsian Discourse: Wakabayashi Han's Kaikyō Sekai to Nihon.” In Rethinking the Russo-Japanese War, 1904-5: Centennial Perspectives, edited by R. Kowner, 263-80. Leiden: Brill.

European Commission. 2018. "Schengen Area," European Commission. Accessed 10 October, 2018. https://ec.europa.eu/home-affairs/what-we-do/policies/ borders-and-visas/schengen_en.

Eurostat. 2018a. “650 000 First-Time Asylum Seekers Registered in 2017.” News release. Eurostat, 20 March. Accessed 19 December, 2018. https://ec.europa. eu/eurostat/documents/2995521/8754388/3-20032018-AP-EN.pdf/ 50c2b5a5-3e6a-4732-82d0-1caf244549e3.

2018b. "Asylum Statistics," Eurostat Statistics Explained. Accessed 16 August, 2018. http://ec.europa.eu/eurostat/statistics-explained/index.php/ Asylum_statistics\#Citizenship_of_first-time_applicants:_most_from_ Syria_and_Iraq.

Fathil, F., and F. Fathil. 2011. "Islam in Minority Muslim Countries: A Case Study on Japan and Korea." World Journal of Islamic History and Civilization 1 (2): $130-41$.

Fukuda, T. [福田 友子]. 2007. “Toransunashonaru na kigyōka tachi: Pakisutanjin no chūkosha yushutsugyō [トランスナショナルな企業家たち：パキスタン人の中 古車輸出業].” In Kokkyō o koeru: Tainichi Musurimu imin no shakaigaku [国境を越える 滞日ムスリム移民の社会学], edited by N. Higuchi, N. Inaba, K. Tanno, T. Fukuda and H. Okai [樋口直人、稲葉 奈々子、丹野清人、福田 友 子、岡井 宏文], 143-77. Tokyo: Seikyūsha [青弓社].

Fukuda, Y. [福田 義昭]. 2010. “Kobe Mosuku konryū: Shōwa senzen-ki no zaishin Musurimu ni yoru nihonhatsu no mosuku konryū jigyō [神戸モスク建立：昭和 戦前期の在神ムスリムによる日本初のモスク建立事業].” Ajia Bunka Kenkyūjo Kenkyū Nenpō [アジア文化研究所研究年報] 45: 32-51.

Green, N. 2013. "Anti-Colonial Japanophilia and the Constraints of an Islamic Japanology: Information and Affect in the Indian Encounter with Japan." South Asian History and Culture 4 (3): 291-313. https://doi.org/10.1080/1947 2498.2013.807126.

Goodwin, M., T. Raines and D. Cutts. 2017. "What Do Europeans Think About Muslim Immigration?" Chatham House, 7 February. Accessed 19 December, 2018. https://www.chathamhouse.org/expert/comment/what-doeuropeans-think-about-muslim-immigration. 
Han Gurōbarizumu Kokusai Hoshu Rengō [反グローバリズム国際保守連合]. 2018. "Isuramu-kyō wa Nihon ni iranai! Shinjuku higashi guchi han-guro getsurei imin, nanmin ukeire danko hantai gaisen [イスラム教は日本にいらない! 新 宿東口反グロ月例移民、難民受け入れ断固反対街宣].” Niconico [ニコニコ動画] video, 93:31, posted 14 April. Accessed 7 October, 2018. http://www. nicovideo.jp/watch/sm33046589.

n.d. “Watashi-tachi no han-gurōbarizumu to wa? [私たちの反グローバリズ ムとは?],” Han Gurōbarizumu Kokusai Hoshu Rengō. Accessed 11 September, 2018. http://anti-globalism.org/.

Hasumi, T. [はすみ としこ]. 2015a. Sōda nanmin shiyō! Hasumi Toshiko no sekai [そ うだ難民しよう！はすみとしこの世界]. Tokyo: Seirindō [青林堂].

. 2015b. “Tteka, ano Shiria nanmin? Hotondo imin daro [ってか,あのシリア 難民?ほとんど「移民」だろw]”, Facebook post，9 September. Archived in Wayback Machine. Accessed 9 April, 2019. https://web.archive.org/ web/20151002183150/https://www.facebook.com/984279651598190/ photos/a.984889011537254.1073741836.984279651598190/12173274782934 $05 /$ type $=3 \&$ permPage $=1$.

Henderson, J. C. 2016. "Muslim Travellers, Tourism Industry Responses and the Case of Japan." Tourism Recreation Research 41 (3): 339-47. https://doi.org/ 10.1080/02508281.2016.1215090.

Higuchi, N. [樋口 直人]. 2007a. “Ekkyō suru shokubunka: Tainichi Musurimu no bijinesu to harāru shokuhin sangyō [越境する食文化：滞日ムスリムのビジネス とハラール食品産業].” In Kokkyō o koeru: Tainichi Musurimu imin no shakaigaku, [国境を越える 滞日ムスリム移民の社会学], edited by N. Higuchi, N. Inaba, K. Tanno, T. Fukuda and H. Okai [樋口 直人、稲葉 奈々子、丹野 清人、福田 友子、岡井 宏文], 116-41. Tokyo: Seikyūsha [青弓社].

. 2007b. “Tainichi Musurimu imin no kiseki o meguru toi [滞日ムスリム移民 の軌跡をめぐる問い.” In Kokkyō o koeru: Tainichi Musurimu imin no shakaigaku [国境を越える 滞日ムスリム移民の社会学], edited by N. Higuchi, N. Inaba, K. Tanno, T. Fukuda and H. Okai [樋口 直人、稲葉 奈々子、丹野 清人、福田 友子、岡井 宏文], 11-23. Tokyo: Seikyūsha [青弓社].

Higuchi, N., N. Inaba, K. Tanno, T. Fukuda, and H. Okai [樋口 直人、稲葉 奈々子、 丹野 清人、福田 友子、岡井 宏文]. 2007. Kokkyō o koeru: Tainichi Musurimu imin no shakaigaku [国境を越える 滞日ムスリム移民の社会学]. Tokyo: Seikyūsha [青弓社].

Hyams, J. 2014. Untitled photograph. In "Judi*, six, at a tented refugee settlement...." Twitter post, 16 September, 4:50pm, posted by Save the Children NZ. Accessed 10 January, 2019. https://twitter.com/SaveChildrenNZ/status/ 512025701026136064 .

Islamic Council of Victoria. n.d. "What is Halal? A Guide for Non-Muslims," Islamic Council of Victoria. Accessed 19 September, 2018. https://www.icv. org.au/about/about-islam-overview/what-is-halal-a-guide-for-nonmuslims/. 
Japan Times, The. 2018. "Japan Marks New Record as Foreign Visitors Top 30 Million in 2018." The Japan Times, 18 December. https://www.japantimes. co.jp/news/2018/12/18/national/japan-marks-new-record-foreign-visitorstop-30-million-2018/.

Japan Tourism Agency [観光庁]. 2018. “Musurimu taiō ni kansuru torikumi ni tsuite [ムスリム対応に関する取り組みについて],” Japan Tourism Agency. Accessed September 30, 2018. http://www.mlit.go.jp/kankocho/page08_000088.html.

2018 [2015]. Musurimu omotenashi gaido bukku [ムスリムおもてなしガイドブ ック]. Accessed 27 December, 2018. http://www.mlit.go.jp/common/ 001235102.pdf.

Kojima, H. 2006. "Variations in Demographic Characteristics of Foreign Muslim Population in Japan: A Preliminary Estimation." The Japanese Journal of Population 4 (1): 115-30.

Komura, F. [小村 不二男]. 1988. Nihon Isurāmu-shi [日本イスラーム史]. Tokyo: Nihon Isurāmu Yūkō Renmei [日本イスラーム友好連盟].

Kyoto Convention and Visitors Bureau. n.d. "Muslim Friendly Kyoto," Kyoto City Official Travel Guide. Accessed 25 September, 2018. https://kyoto.travel/en/ muslim.

Luqiu, L. R., and F. Yang. 2018. "Islamophobia in China: News Coverage, Stereotypes, and Chinese Muslims' Perceptions of Themselves and Islam." Asian Journal of Communication 28 (6): 598-619. https://doi.org/10.1080/01292986.2018.1 457063.

Matsumoto, T. [松本 高明]. 2006. “Nihon no kōkōsei ga idaku Isurāmu-zō to sono zesei ni muketa torikumi [日本の高校生が抱くイスラーム像とその是正に向けた 取り組多].” Nihon Chutō Gakkai Nenpō [日本中東学会年報] 21 (2): 193-214.

Matsunaga, A. [松長 昭]. 2009. Zainichi Tatāru-jin: Rekishi ni honrō sareta Isurāmu kyōto-tachi [在日タタール人: 歴史に翻弄されたイスラーム教徒たち]. Tokyo: Tōyō Shoten [東洋書店].

Mie, A. 2016. "Japan to Take in 150 Syrians as Exchange Students after Criticism of Harsh Refugee Policy." The Japan Times, 20 May. Accessed 20 December, 2018. https://www.japantimes.co.jp/news/2016/05/20/national/japan-take150-syrians-exchange-students-criticism-harsh-refugee-policy/.

Ministry of Education, Culture, Sports, Science and Technology. 2012. Higher Education in Japan. Accessed 11 May, 2019. http://www.mext.go.jp/en/policy/ education/highered/title03/detail03/__icsFiles/afieldfile/2012/ 06/19/1302653_1.pdf.

Ministry of Justice. 2018. “Wagakuni ni okeru nanmin higo no jōkyōtō [我が 国における難民庇護の状況等].” Accessed 27 July, 2018. http://www.moj. go.jp/content/001254269.pdf.

Miura, T. 2006. "Perceptions of Islam and Muslims in Japanese High Schools: Questionnaire Survey and Textbooks." Annals of Japan Association for Middle East Studies 21 (2): 173-91. 
Miura, Y. 2015. "Goto, Yukawa Mourned in Spontaneous Gatherings Nationwide." The Japan Times, 9 February. Accessed 10 October, 2018. https://www. japantimes.co.jp/news/2015/02/09/national/goto-yukawa-mournedspontaneous-gatherings-nationwide/.

Nasralla, S., and F. Murphy. 2017. "Austria's Kurz Strikes Deal to Bring Far Right into Government." Reuters, 16 December. Accessed 19 December, 2018. https://uk.reuters.com/article/uk-austria-politics/austrias-kurz-strikesdeal-to-bring-far-right-into-government-idUKKBN1E91O1.

Nippon.com. 2013. “Tokyo Camii: Japan’s Biggest Mosque.” Nippon.com, 19 June. Accessed 12 January, 2018. https://www.nippon.com/en/features/c01301/.

Nordland, R. 2015. “ISIS Says It Has Killed 2nd Japanese Hostage." The New York Times, 31 January. Accessed 10 October, 2018. https://www.nytimes. com/2015/02/01/world/middleeast/islamic-state-militants-japanesehostage.html.

Numata, S. 2012. "Fieldwork Note on Tatar Migrants from the Far East to the USA: For Reviews of Islam Policy in Prewar and Wartime Japan." Annals of Japan Association for Middle East Studies 28 (2): 127-44.

Office of the United Nations High Commissioner for Human Rights. 2014. "Committee on the Elimination of Racial Discrimination considers report of Japan." United Nations Human Rights Office of the High Commissioner, 21 August. Accessed 8 September, 2018. https://www.ohchr. org/en/NewsEvents/Pages/DisplayNews.aspx?NewsID=14957.

OIC (Organisation of Islamic Cooperation). 2019. "History," Organisation of Islamic Cooperation. Accessed 27 May, 2019. https://www.oic-oci.org/page/?p_ id $=52 \& p \_r e f=26 \& l a n=e n$.

Okai, H. [岡井 宏文]. 2007. “Isurāmu nettowāku no tanjō: Mosuku no setsuritsu to Isurāmu katsudō [イスラーム・ネットワークの誕生 : モスクの設立とイスラーム活 動].” In Kokkyōo koeru: Tainichi Musurimu imin no shakaigaku [国境を越え る 滞日ムスリム移民の社会学], edited by N. Higuchi, N. Inaba, K. Tanno, T. Fukuda and H. Okai [樋口 直人、稲葉 奈々子、丹野 清人、福田 友子、岡井 宏文], 178-209. Tokyo: Seikyūsha [青弓社].

Osaki, T. 2015a. "Manga Artist Hasumi Stirs Outrage Again with New Book Slammed as Racist." The Japan Times, 22 December. Accessed 11 September, 2018. https://www.japantimes.co.jp/news/2015/12/22/national/socialissues/manga-artist-hasumi-stirs-outrage-new-book-slammed-racist/.

. 2015b. "Manga Artist Removes Illustration Mocking Syrian Refugee." The Japan Times, 5 October. Accessed 11 September, 2018. https://www. japantimes.co.jp/news/2015/10/08/national/social-issues/manga-artistremoves-illustration-mocking-syrian-refugee/.

. 2015c. "'Racist' Illustration of Refugee Girl Sparks Ire Among Japan's Netizens." The Japan Times, 2 October. Accessed 11 September, 2018. https:// www.japantimes.co.jp/news/2015/10/02/national/social-issues/racistillustration-refugee-girl-sparks-ire-among-japans-netizens/. 
Park, S. N. 2018. "South Korea Is Going Crazy Over a Handful of Refugees." Foreign Policy, 6 August. Accessed 16 August, 2018. https://foreignpolicy.com /2018/08/06/south-korea-is-going-crazy-over-a-handful-of-refugees/.

Sakurai, K. [桜井 啓子]. 2003. Nihon no Musurimu shakai [日本のムスリム社会]. Tokyo: Chikuma Shobō [筑摩書房].

Satō, K. [佐藤 兼永]. 2015. Nihon no naka de Isuramu kyōo shinjiru [日本の中でイス ラム教を信じる]. Tokyo: Bungei Shunjū [文藝春秋].

Shibuichi, D. 2015. "Zaitokukai and the Problem with Hate Groups in Japan." Asian Survey 55 (4): 715-38. https://doi.org/10.1525/as.2015.55.4.715.

Statistics Bureau. 2018. "Monthly Report," Statistics Japan. Accessed 16 August, 2018. http://www.stat.go.jp/english/data/jinsui/tsuki/index.html.

Takigawa, C. 2013. "Presentation by Tokyo, Japan." Speech to the International Olympic Committee. 125th IOC session, Buenos Aires, 7 September. YouTube video, 1:02:41, posted by Olympic Channel, 10 September. Accessed11January,2019.https://www.youtube.com/watch?v=frLZeeU9760.

Tanada, H. [店田 廣文]. 2008. "Islamic Studies in Wartime Japan: An Analysis of Historical Materials of the Greater Japan Muslim League." Annals of Japan Association for Middle East Studies 23 (2): 215-36.

. 2013. "Islamic Research Institutes in Wartime Japan: Introductory Investigation of the 'Deposited Materials by the Dai-Nippon Kaikyo Kyokai (Greater Japan Muslim League)'”' Annals of Japan Association for Middle East Studies 28 (2): 85-106.

2015. Nihon no mosuku [日本のモスク]. Tokyo: Yamakawa Shuppansha [山 川出版社].

2018a. "Nihon ni okeru Isurāmukei shūkyō dantai to komyuniti [日本におけ るイスラーム系宗教団体とコミュニティ].” Shakai bunseki [社会分析] 45: 752-94.

.2018b. “Nihonjin Musurimu to wa dare no koto ka: Nihon ni okeru Isurāmu kyōto (Musurimu) jinkōnogenzai [日本人ムスリムとは誰のことか: 日本における イスラーム教徒(ムスリム)人口の現在].” Shakaigaku nenshi [社会学年誌] 59: $109-28$.

Tanada, H., K. Ishikawa and H. Okai [店田 廣文、石川 基樹、岡井 宏文]. 2013. Gaikokujin jūmin to no kyōsei ni kansuru ishiki chōsa: Fukuoka-shi hōkokusho [外国人住民との共生に関する意識調查 福岡市報告書]. Tokyo: Institute for Multi-ethnic and Multi-generational Societies [多民族・多世代 社会研究所]. Accessed 24 May, 2018. http://imemgs.com/document/2013ga ikokujinishikichousa.pdf.

2014. Attitude Survey on Foreign Nationals Imizu City Report. Tokyo: Institute for Multi-ethnic and Multi-generational Societies. Accessed 24 May, 2018. https://imemgs.com/document/2014irumi.pdf. 
Tanada, H., and H. Okai. [店田 廣文、岡井 宏文]. 2011. Gaikokujin ni kansuru ishiki chōsa: Gifu-shi Hōkokusho [外国人に関する意識調査＼cjkstart岐阜市報告書]. Tokyo: Institute for Multi-ethnic and Multi-generational Societies [多 民族・多世代社会研究所]. Accessed 24 May, 2018. http://imemgs.com/ document/gifusurvey.pdf.

Tourism Strategy Promotion Task Force. 2018. Hōnichi Musurimu ryokōsha taiō no tame no akushon puran [訪日ムスリム旅行者対応のためのアクション・ プラン]. Accessed 27 December, 2018. http://www.mlit.go.jp/common/ 001235639.pdf.

Turner, G. 1997. "Media Texts and Messages." In The Media in Australia: Industries, Texts, Audiences, edited by S. Cunningham and G. Turner, 293-347. St Leonards, NSW: Allen and Unwin.

Wilson, T. 2018. "Japanese Court Throws Out Syrians' Bid to Overturn Refugee Ruling." Reuters, 20 March. Accessed 18 December, 2018. https://www. reuters.com/article/us-japan-refugees/japanese-court-throws-out-syriansbid-to-overturn-refugee-ruling-idUSKBN1GW0M2.

Yamagata, A. 2017. "Conflicting Japanese Responses to the Syrian Refugee Crisis." The Asia-Pacific Journal: Japan Focus 15 (24), no. 2. Accessed 30 May, 2019. https://apjjf.org/2017/24/Yamagata.html.

Yamaguchi, T. 2013. "Xenophobia in Action: Ultranationalism, Hate Speech, and the Internet in Japan." Radical History Review (117): 98-118. https:// doi.org/10.1215/01636545-2210617.

Yomiuri Shimbun. [読売新聞]. 2015. “Isesaki mosuku kyūshutsu nozomu [伊勢崎モ スク 救出望む].” Yomiuri Shimbun (Morning edition, Gunma), 27 January. p. 33.

. 2016a. “Mosuku bōhan de chīki kōryū [モスク 防犯で地域交流]." Yomiuri Shimbun (Morning edition, Chiba), 27 September. p. 31.

2016b. “Musurimu dantai no reihaijo ni kyōhakubun [ムスリム団体の礼拝所 に劦迫文].” Yomiuri Shimbun (Morning edition, Shizuoka), 14 July. p. 33.

. 2016c. “Musurimu hōnichi kangeitaisei [ムスリム訪日＼cjkstart歓迎態勢].”Yomiuri Shimbun (Morning edition, Shizuoka), 28 January. p. 31.

.2018a. “Fuji-tennensui harāru ninshō [富士天然水ハラール認証].” Yomiuri Shimbun (Morning edition, Yamanashi), 5 January. p. 30.

2018b. Media Data 2018. Accessed 11 September, 2018. https://adv.yomiuri. co.jp/m-data/english/download/yomiuri_MD2018.pdf\#page=3. 


\section{The Ruptures of Rhetoric: Cool Japan, Tokyo 2020 and Post-3.11 Tohoku}

\section{PEPI RONALDS}

Monash University

\section{ABSTRACT}

Policymakers in Japan have adopted a discourse to link the Tokyo 2020 Olympics to the recovery of Japan's northern Tohoku region following the March 2011 triple disaster (3.11). This discourse has created a dissonance between 3.11-affected communities, policy-makers and wider Japan. To understand this dissonance, this article explores the implicit agendas behind Japan's Olympics efforts (such as positioning sports as a facilitator and symbol of recovery), its Cool Japan initiative (as a nation-branding and nation-building strategy) and other actions (such as labelling the 2020 event 'the Reconstruction Olympics'). It then analyses the opinions of people from affected areas, gathered through interview research and from popular media, to demonstrate that the use of recovery rhetoric to promote the Olympics is being poorly received among some in 3.11-affected communities. Community concerns circle around availability of construction resources as well as the fact that recovery is not yet complete. This article contends that the events of 3.11, combined with the pursuit of the Olympics, has effected changes in the social imaginary and in regional ideas of belonging among 3.11-affected communities.

\section{KEYWORDS}

3.11; contemporary; Cool Japan; nationalism; rebuilding; recovery; Tohoku; Tokyo 2020 Olympics
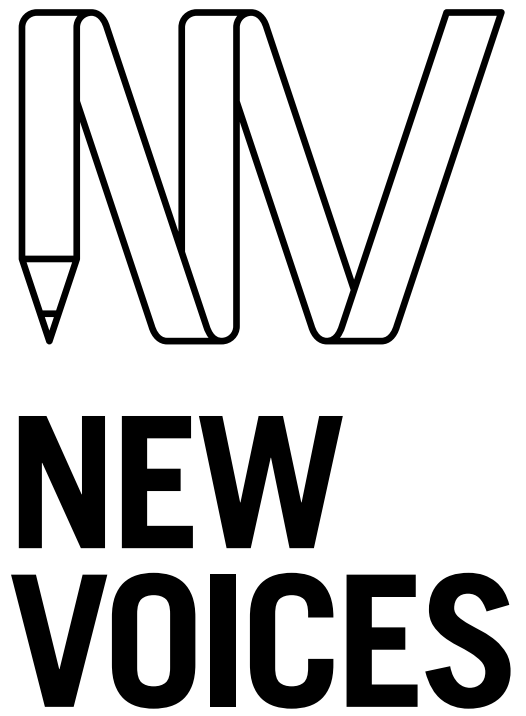

IN JAPANESE STUDIES

JAPANFOUNDATION \& BRINGING JAPAN TO YOU

To link to this article: https://doi.org/10.21159/nvjs.11.02

\section{ISSN 2205-3166}

New Voices in Japanese Studies is an interdisciplinary, peer-reviewed journal showcasing the work of emerging scholars with ties to Australia or New Zealand and research interests in Japan.

All articles can be downloaded free at newvoices.org.au

(c) The Japan Foundation, Sydney and Pepi Ronalds, 2019

\section{(c) $(1)$}

This work is licensed under a Creative Commons Attribution-NonCommercialNoDerivatives 4.0 International License. 


\section{INTRODUCTION}

At the closing ceremony of the Rio Olympics in August 2016, Japanese Prime Minister Shinzo Abe made an appearance. He rose from a giant green pipe costumed as one of Japan's most popular cultural exports: Super Mario. Abe's appearance was heralded with a short, polished big-screen film production that elicited loud cheers from the stadium crowd. In the film, the nation's top athletes trained alongside popular attractions and tropes like Tokyo Tower and the shinkansen. There were images of skyscrapers, Tokyo station, cherry blossoms and the Ginza. Interspersed with these 'real-world' images were scenes from anime and appearances from cartoon characters like Hello Kitty, Pacman, Mario and Doraemon. The film portrayed Abe's journey from Japan to Rio, morphing into a cartoon Mario en route. Enabled by a tool from Doraemon's $4 \mathrm{D}$ pocket, the cartoon Mario-Abe shot into a tunnel to Rio through the centre of the earth. In the real Rio Olympic stadium-where the crowd was hyped by a countdown, flashing lights and the Super Mario game's shrill Power Up jingle-the costumed Abe appeared from the pipe and confidently waved Mario's red hat. He then raised a red ball high in his outstretched arms, and with that, the symbolic Olympic handover from Rio to Tokyo was complete.

The film covered all the cultural tropes foreign consumers expect from Japan-from the old-style magic of traditional sights, to its embrace of technology and animated characters. In appropriating Mario, Doraemon, Hello Kitty and Pacman (all symbols of Japan's creative exports), Abe was engaging a wider national scheme known as Cool Japan. According to Japan's Cabinet Office website, the concept of Cool Japan "covers all aspects of Japanese culture from subcultural products, such as manga and Japanimation, to traditional cultural heritage" (Cabinet Office 2014, 2). Described as "an initiative to further strengthen the ties between Japan and other countries (in such areas as economics, culture, and diplomacy)" (Cabinet Office n.d.), Cool Japan is part of a nation-branding effort aimed at positioning Japan and its cultural exports in the global marketplace (Valaskivi 2013). Cool Japan was first applied as a slogan to Japan's nation-branding projects in the mid-2000s (Valiskivi 2013, 485), and continues to be described variously as a 'policy', 'strategy' and 'initiative' (METI 2016; Cabinet Office n.d.). Policy-makers' primary aim in promoting Cool Japan is nation branding that "can be seen as a conscious effort to influence the social imaginary of a nation" (Valaskivi $2013,486)$. 'Social imaginary' is drawn from the work of Taylor (2004), who describes it as:

the ways people imagine their social existence, how they fit together with others, how things go on between them and their fellows, the expectations that are normally met, and the deeper normative notions and images that underlie these expectations.

(23)

As an exercise in promoting Cool Japan, hosting the 2020 Olympics is an effort towards both nation-branding and nation-building. But what is the effect of the 2020 Olympics effort (and its attendant rhetoric) on the social 
imaginary of disaster-affected Japanese citizens in the context of Japan's recent history? The following discussion explores this question.

\section{ELEPHANT IN THE STADIUM}

Earlier in the ceremony an ambiguous nod was made toward what was, for many, the elephant in the stadium. The words "Thank you" were displayed in dozens of languages, including "Thank you for your support" in English. While nothing more was included in the display itself, Australian broadcast commentator Joanna Griggs drew a direct line between the words and the calamity known as 3.11: "The Japanese, taking the opportunity to thank the people of the world for their support following the horrendous earthquake they suffered from in March 2011-that caused so much destruction, loss of lives, and injuries" (Griggs in Wilson, 2016). Here Griggs acknowledges the triple disaster-an event which the people of Tohoku had borne the brunt of just five years before. ${ }^{1}$

3.11 comprised a magnitude 9.0 earthquake, a tsunami that reached heights of over 40 metres and inundated 560 square kilometres, and a nuclear meltdown at the Tokyo Electric Power Company's (TEPCO) Fukushima Daiichi nuclear power plant, sending a plume of radiation through the area. As a result of the disaster, 15,896 people lost their lives and 2,536 are still missing (National Police Agency 2018). On 24 April 2011 (within six weeks of the disaster) there were over 340,000 evacuees (Reconstruction Agency 2011); a year after the Rio closing ceremony-five years after 3.11-that number had less than halved to 119,000 (Reconstruction Agency 2017). Two years out from the Tokyo 2020 Olympics and seven years after 3.11, 65,000 people were still without permanent homes (Reconstruction Agency, 2018a). At the time of writing, the number of people still living in temporary housing is 57,000 (Reconstruction Agency, 2018b).

Although the handover at the closing ceremony in Rio only minimally acknowledged 3.11, more direct connections have been made between the two events within Japan. At times, domestic politicians have labelled the Tokyo Olympics 'the Reconstruction Olympics' (復興五輪; fukkō gorin) and many key players in the Tokyo Olympic effort have positioned sports as a facilitator and symbol of recovery. ${ }^{2}$ For example, in an English-language press release about the forthcoming Torch Relay and plans for the relay to pass through Tohoku, John Coates (IOC Coordination Commission Chair for Tokyo 2020) said:

We hope that this symbolic act will underline the Olympic Movement's support for the citizens of [the affected] regions, as well as allowing them to show the watching world the progress that they have made in rebuilding their lives and inspiring the local children through the Olympic values.

(IOC 2018) 
By hosting a so-called 'Recovery Olympics' alongside the Cool Japan campaign, the 2020 Olympics can be seen as an effort to influence the social imaginary of both the Japanese nation and international audiences. However, what effects, if any, are these efforts having on the social imaginaries and perspectives of those in the north? Drawing on individual voices expressed in interview research as well as others from popular media, this article contends that despite efforts on the part of Olympics organisers and Japan's political elites, the nation-building aspect of the Tokyo 2020 Olympics is failing for many in the region directly affected by 3.11 .

\section{METHODOLOGY AND LIMITATIONS}

Since 2014 I have conducted annual, open-ended and semi-structured interviews with individuals in Miyagi prefecture to understand how their lives have been affected by $3.11 .^{3}$ The interviews are part of a larger project: a creative nonfiction manuscript which aims to document the longer-term challenges, hopes and achievements of these individuals. ${ }^{4}$ Because of the nature of creative non-fiction-where limitations are often explicitly documented in the storytelling-my process allows for more fluidity in the data gathering than social-science disciplines.

The interviewees were recruited via my professional and personal contacts in Miyagi and later through snowballing introductions. They include people whose homes and/or communities were inundated by the tsunami, as well as people who work or otherwise participate in reconstruction in either volunteer or paid roles. My most recent interviews were conducted in October 2018. I used interpreters to conduct the interviews, which are audio-recorded and partially transcribed by myself.

I have conducted over 80 interviews, increasing and decreasing my pool of interviewees on a needs basis. Around 40 of these interviews were conducted with a core group of 12 or so individuals who were interviewed annually over multiple years. Approximately $80 \%$ of the interviewees are men over 40 years of age, with a little under $50 \%$ being men over 50 years of age. The gender and age profile of this group is an unintentional product of the process of recruiting participants (primarily through introductions), the aging demographic of the region and historical practices which make it more likely for older men to hold spokesperson positions within organisations and communities. I approached analysis of the interviews with an awareness of the biases which such a skewed participant profile may reflect.

In 2014, an interviewee volunteered his perception that soon after the winning Olympic bid was announced in 2013, the number of construction vehicles present in his district was visibly reduced (Kogure 2014). After hearing this

\footnotetext{
3 I have limited my research to Miyagi, deliberately omitting Fukushima as a focus. This is not to discount the monumental challenges faced by communities in Fukushima, but to recognise that there are already many other accounts about their experiences available in English. For a more detailed understanding of the events around the meltdown, see Cleveland's 2014 article, "Significant Breaking Worse" and Willacy's 2013 book, Fukushima: Japan's Tsunami and the Inside Story of the Nuclear Meltdowns.

4 Creative nonfiction is a form of literary storytelling which Gutkind defines as "factually accurate prose about real people and events_in a compelling, vivid, dramatic manner" $(2012,6)$.
} 
comment, I specifically sought the opinions of other interviewees in 2015 with the question, 'In what ways, if any, has the 2020 Olympics work helped or hindered your community in recovery? ${ }^{25}$ Opinions on the Olympics thereafter comprised one of about a dozen different topics discussed each year with the core group of people. By 2018 the Olympics question had become, 'How are you/is your community feeling about the so-called Recovery Olympics at this stage?'

My intention is to report my interviewees' perceptions rather than critique their positions. While the quotes used in this paper generally express negative sentiments, most of my interviewees prefaced their response to questions about the Olympics by acknowledging beneficial outcomes such as enhanced tourism and nation-branding, as well as the potential for sports to bring people together and uplift a nation after calamity. But with the exception of one person, these outcomes have not swayed them from questioning the Japanese government's pursuit of the Olympics when so much practical recovery work still needs to be achieved.

\section{LITERATURE REVIEW}

\section{Olympics: Showcasing a Nation}

The act of hosting the Olympic Games is an opportunity for governments to showcase a nation in the global context, as well as create "a source of national and civic pride" (Martin 2000, 19). The Olympic Games promote a particularly heightened sense of nationhood, and are seen by governments as an opportunity to reconsider and foster national identity (Berry 2013, 87). Thus, in the lead-up to and during the Olympics, images and rhetoric circulate in the service of national goals, promoting legacies and nation-brands. The term 'Recovery Olympics' as applied to Tokyo 2020 appears to meet these goals, marking the event itself as a legacy and helping international and national audiences to imagine Japan as recovered from 3.11. But as evacuee statistics and other evidence shows, in 2018 Tohoku had not yet overcome 3.11.

\section{National Identity}

By defining a nation as an invention which is limited, sovereign and imagined as a community, Anderson $(1983,6)$ helps to explain why a nation might host the Olympics despite a challenge like recovery from 3.11. "Imagined communities" can be informed by the official narratives of dominant groups (Anderson 1983, 101) and media representations help to circulate them (37-46). In the context of Tokyo 2020, the Japanese national government can be considered a dominant group cultivating an imagined community by circulating the image of Japan as a post-recovery Olympic host. Taylor's concept of the social imaginary builds on Anderson's work by exploring how "ordinary people 'imagine' 
their social surroundings" and illuminating how this "makes possible common practices and a widely-shared sense of legitimacy" (Taylor 2004, 23). Taylor's work recognises the contribution that our everyday interactions make to our imagined selves and highlights how everyday practices can inform these (despite the efforts by dominant groups which Anderson identifies). Together, Taylor and Anderson demonstrate the porousness of identity, and how associations are influenced by the push and pull of narratives in personal and wider social orbits. This tug is also visible in Japan's efforts towards constructing a particular imagined community and social imaginary pertaining to the 'Recovery Olympics' and Cool Japan.

\section{Human Security and Resilient Nationalism}

Part of what informs the social imaginaries of those directly affected by 3.11 is their experience of the aftermath of the disaster. Shani contends that the events of 3.11 "revealed the inability of a modern, industrialized nation-state to protect its own citizens, shattering the public's trust in the government" $(2016,129)$. This trust was largely undermined due to a failure in protecting the human security of those affected. ${ }^{7}$ Shani's examples of this failure include the 150,000 people still in temporary housing and the limited compensation provided to those displaced by the radiation (Shani 2016, 133). He argues that after 3.11, '"racialized' biopolitical divisions between 'inside' and 'outside', which had hitherto been used to distinguish colonial and ethnic minorities, became (re)inscribed within the Japanese nation" (2016, 132; italics original). ${ }^{8}$ According to Shani, the government's widely criticised response to the disaster created a "space for the articulation of a discourse of resilient nationalism, which underpins the current Abe administration" (2016, 129; italics original). This nationalism was expressed in the catchphrase Ganbaro Nippon ("Let's do our best, Japan”), which became a popular slogan of encouragement from across Japan towards those affected. As Shani suggests, this phrase "abnegates all responsibility from the state for [the protection of residents in disasterhit areas] and displaces it onto the affected communities themselves" (2016, 130). A part of the response to that abnegation was the appearance of localised Ganbarō slogans (Shani 2016, 136). As will be discussed below, these placespecific slogans shone a light on who exactly was doing their 'best'. Was it the entire nation? Or those whose human security was affected by the disaster? Shani's consideration of human security and resilient nationalism will be applied in this article to understand the ways in which national and local perspectives have diverged.

\section{Nation Branding, Cool Japan and Soft Power}

While resilient nationalism is not necessarily a formal strategy employed

\footnotetext{
7 The United Nations summarises human security as "the right of all people to live in freedom and dignity, free from poverty and despair...from fear and...want, with an equal opportunity to enjoy all their rights and fully develop their human potential" (United Nations, 2005, 31).

8 Shani writes that despite constitutional rights to equality in Japan, institutional discrimination along "racialized" lines has historically existed towards minority 'outsiders' such as "Buraku and Ainu; people and descendants of Japan's former colonies in Korea and China; foreigners and migrants from other parts of Asia and the rest of the world" $(2016,132)$. Paraphrasing Satō, Shani says these "racialized" others were "the referent objects for human security, as a tool of Japanese foreign policy” (Satō 2007 in Shani 2016, 129).
} 
by the Abe administration, Cool Japan certainly is. Cool Japan is a form of cultural diplomacy, or soft power, which leverages Japan's creative assets in the global marketplace. The concept came to the fore amidst Japan's economic collapse of the late 1990s and the growing realisation that promoting Japan's creative products could help its struggling economy (Daliot-Bul, 2009, 247). Cool Japan has been linked by Daliot-Bul (2009), Valaskivi (2013), Iwabuchi (2015) and others to journalist McGray's 2002 Foreign Policy article, Japan's Gross National Cool. In the article, McGray celebrates Japan's success in making "deep inroads into American culture" $(2002,46)$ via creative industry products. "Instead of collapsing beneath its political and economic misfortunes, Japan's global cultural influence has only grown," writes McGray $(2002,47)$. As the introduction to this paper demonstrates, Cool Japan has been deployed as a tool to promote the 2020 Olympics.

The term 'soft power' is drawn by McGray (2002) and others (Daliot-Bul 2009, 248; Iwabuchi 2015, 422) from the work of Joseph S. Nye, Jr. Daliot-Bul writes, "in a great shift from the more traditional power structures, 'soft' power derives mostly from intangible resources such as culture and ideology rather than from military action or economic incentives" $(2009,248)$. Cool Japan is an exercise in soft power. And in drawing upon and applying Cool Japan resources in its marketing campaign, the Tokyo 2020 Olympics can be seen as an effort in soft power and transnational nation branding.

\section{Nation Building}

Scholars concur that outward-looking policies like Cool Japan are also efforts in inward-looking nation building. Iwabuchi, for example, writes that:

Cultural diplomacy maneuvered in conjunction with nation branding is not only directed externally, but also internally, as a tool for inculcating a narrative of the nation and a sense of national belonging.

$(2015,427)$

Daliot-Bul notes that initiatives like the Japan Brand Strategy, of which Cool Japan is a part, are "seen as a means to revitalize patriotic pride and recruit those patriotic feelings for national ends" $(2009,260)$. Similarly, Valaskivi observes that while policies like Cool Japan aim to influence the international brand, their influence domestically cannot be ignored:

a nation brand [is] much more than marketing measures directed towards other countries. It becomes a part of the social imaginary in the construction of national identity, at least among the elites undertaking the branding task.

(2013, 490; my italics)

Valaskivi's "elites undertaking the branding task" includes politicians, bureaucrats and the socially powerful, such as the representatives from private and government sectors who comprised the Cool Japan Advisory Council (CJAC). Iwabuchi (2015), Daliot-Bul (2009) and Valaskivi (2013) all demonstrate how outward-facing nation branding is intrinsically linked 
to inward-facing nation-building. To this end, not only are the Tokyo 2020 Olympics an effort to showcase Japan to the world, but also to develop national pride and belonging within Japan.

\section{Creating a New Japan}

In May 2011, the CJAC produced a proposal document, Creating a New Japan, which was available on the Ministry of Economy, Trade and Industry (METI) website (METI 2011). The Creating a New Japan proposal "connects enhancing the 'Japan Brand' with rebuilding the nation after the Great East Japan Earthquake" (Valaskivi 2013, 485). Work on the proposal had commenced in November 2010, prior to 3.11, but the version published in May 2011 "began by tying branding efforts to recovery and rebuilding" (Valaskivi 2013, 487) and documented initiatives to help 3.11-affected areas (METI 2011, 15). As this example shows, the national government was quick to leverage the Cool Japan strategy as part of a recovery rhetoric. But the Creating a New Japan proposal also noted how 3.11 had "severely damaged consumers' perception of Japanese products...and [was] affecting exports...as well as the number of overseas tourists to Japan" $(2011,4)$. Because of this, the document reads, "Japan must work quickly to dispel any short-term negative impact...tell the world of the unshakably strong qualities of Japan...[and] send out messages that utilise the power of sympathy" (METI 2011, 12). One of the document's key goals was "Overcoming the Earthquake [by] restoring the shine of the 'Japan Brand"' $(2011,1)$. Therefore, while Japan is using the Olympics as a platform for its international Cool Japan nation-branding effort, it is also drawing connections between the Olympics and the events of 3.11 through devices such as the Creating a New Japan proposal and the 'Recovery Olympics' moniker.

\section{The Recovery Olympics' Legacy as Cool Japan}

In using these devices, the Japanese government and the IOC are deploying what Tomlinson calls a "legacy discourse" (2014, 138): a narrative "[d] eveloped as a principle to justify the Olympic phenomenon at a time of crisis and survival...[and] turned into a rhetorical tool" $(2014,139)$. Tomlinson's work explores a variety of "legacy claims" $(2014,137)$, including the bid for the Tokyo 2020 Games. Tomlinson's conclusion can be read as a commentary on the Tokyo 2020 project: "legacy rhetoric pervades contemporary Olympic discourse despite strong evidence on many fronts that the harsh realities contradict the legacy hopes and aspirations" $(2014,151)$. In the case of the Tokyo 2020 Olympics, the legacy rhetoric includes the label 'Recovery Olympics' as well as previously cited claims such as "support for the citizens of [the 3.11-affected] regions" (Coates in IOC 2018).

Valaskivi argues that the "circulation" of nation branding allows "a particular social imaginary [to be] formulated, represented, and reproduced and transformed in different localities" $(2013,485)$. Consequently, how the

(2)


Olympics efforts are imagined in one region of Japan might well be different in other regions. Tomlinson's work casts doubt on the government's stated intentions to support post-3.11 recovery through the Olympics. The sentiments of my interviewees also reflect this view: they see little reason for the Olympics to be held in Japan in 2020 because, seven years on from the disaster, recovery in 3.11-affected regions is still underway.

\section{Disaster Recovery}

The concept of disaster recovery encompasses three key and interrelated meanings: "the restoration of normal community activities that were disrupted by disaster impacts", "a phase in the emergency management cycle that begins with stabilization of the disaster conditions" and "a process by which the community achieves the goal of returning to normal routines" (Lindell 2013, 812; my italics). In the context of Japan - a highly industrialised nation-one can attach 'fulfilling the needs of human security' to Lindell's description of "returning to normal routines". At the very least, therefore, 'recovery' from 3.11 can be understood to involve practical things such as permanent housing for those who lost their homes and employment for those who lost their livelihoods. Nonetheless, when the Tokyo 2020 Olympics were awarded in 2013, recovery at these most basic levels had not been achieved. ${ }^{9}$ Indeed, by the time of Abe's performance at the Rio 2016 closing ceremony, and as this article is being written (in 2018), the application of Lindell's definition shows that recovery in Tohoku is still a long way off.

\section{RUPTURE}

There were economic consequences to the events of $3.11 .^{10}$ Not only were places of business and production completely destroyed by the earthquake and tsunami, but infrastructure such as ports, roads and railways were also undermined. Global and national supply chains were disrupted and the loss of life, heartbreak and consequent migration from affected towns resulted in decreased productivity and population drops. But the CJAC's (previously cited) post-3.11 goal of restoring Japan's national brand demonstrates a divergence between the concerns of disaster-affected communities and Tokyobased political elites. While the elite polished the 'Japan Brand', hundreds of thousands in evacuation centres (Reconstruction Agency 2016, 10) dealt with traumatic experiences and faced uncertain futures.

This was not the first divergence of elites from survivors pertaining to 3.11. While Japan's Self Defence Forces (SDF) were mobilised within an hour of the tsunami, Richard Samuels (2013) writes of the many later missteps and bungles that Prime Minister Naoto Kan (Democratic Party of Japan) and his government wrought in the immediate aftermath (9-16). These include inefficiency through micromanaging, lack of clarity between headquarters (e.g., between Headquarters for Special Measures to Assist the Lives of Disaster

9 For example, in 2013 there were still 282,000 evacuees living in temporary housing (Reconstruction Agency 2013, 1).

10 For an initial overview of the economic impacts, see Komine (2011).

Pepi Ronalds

New Voices in Japanese Studies,

Vol. 11, 2019, pp. 26-46 
Victims and the Recovery Agency), a "poisoned political atmosphere" and inadequate circulation of important information (2013, 10-15). The government's failures pertaining to the unfolding situation at TEPCO's Fukushima nuclear power plants are explicitly documented by the National Diet's Fukushima Nuclear Accident Independent Investigation Commission, which states in an official report that " $[\mathrm{t}]$ he government failed in its responsibility to the public" (NAIIC 2012, 35) and that "the government, the regulators and TEPCO...effectively betrayed the nation's right to be safe from nuclear accidents" (16).

Events like those at TEPCO's plants, as well as the scope of the disaster, meant that the human security of those directly affected on March 11, 2011 and in the immediate aftermath was undermined, with the result that "faith in the state was badly shaken" (Shani, 2016, 136). While Aldrich $(2017,39)$ notes that a "trust deficit" between the Japanese and their government is not a phenomenon unique to post-disaster Japan and was evident as early as the 1980s, he recognises that the government's response to 3.11 "undermined what little trust citizens had in their elected officials and in their bureaucracy" (47). Shani concurs, observing that the disaster "revealed the inability of a modern, industrialised nation-state to protect its own citizens... and in so doing, endangered national cohesion" $(2016,129)$. While the moment of 3.11 was a disaster in itself, the government's response in its aftermath aggravated the difficulties being experienced by those affected.

A nation-branding (and nation-building) event such as the 2020 Olympics may present itself as a perfect solution to a lack of national cohesion. Yet, far from defining a social imaginary shared across Japan, many in Tohoku have felt an ongoing discord between their own recovery needs and the (in)action and rhetoric of their national government as it pertains to the resources allocated to the Olympics. Tohoku communities were disappointed with the government's response in the immediate wake of the disaster (see Shani 2016; Samuels 2013). As will be outlined below, more recently they have been disappointed by the government's decision to pursue the Olympics agenda, and by its efforts to leverage recovery rhetoric within that pursuit.

\section{RHETORIC}

A video uploaded to YouTube by the Tokyo Metropolitan Government in 2016, titled See You in Tokyo and Tohoku 2020, exemplifies recovery rhetoric being employed as part of the Olympics message. The video starts with audio and images showing the destruction wrought by 3.11. Initially backgrounded by solemn piano music, the tone significantly shifts within a few moments and the video transforms. Uplifting music plays alongside spectacular images of fishing boats resplendent with tairyō-bata (大漁旗; flags traditionally used signify a big haul) on a clear sunny day. As the boats glide in formation across a vivid blue sea, the traditional tairyo-bata are replaced by flags of foreign countries billowing in the wind. Soon, the video shows children: in gyms, baseball fields and swimming pools, smiling, laughing and playing. "When 
we were looking for a way forward, it was sport that gave us the strength to find it," a narrator says in English. One of the children talks about sport and friendship, and wheelchair tennis player Shingo Kunieda reinforces a message of ongoing connection between people (in Japanese, with English subtitles). Then, the narrator returns: "Sport helped us regain a sense of normality, and take a step towards a new future." After more smiles, waves and "arigatō"s the music hits its peak and the video ends with four dramatically delivered words: “Tohoku. Japan. The World." (TMG 2016).

Another video on the same channel made after the disastrous earthquake in Kumamoto, April 2016, echoes the same sentiment. "Sport teaches us the joy of meeting people, forming bonds and sharing a strong passion," it claims (TMG 2018). This video is titled See you in Tokyo and Kumamoto in 2020. The implication in both of these videos is that the Olympics efforts are having (and can have) a positive effect on recovery. While there may be some recovery benefits of sports, (and some Tohoku residents may hope that the Olympics will bring visitors and tourism income), most of my interviewees have drawn links between the Olympics announcement and slowing recovery in Tohoku, as will be discussed below.

\section{COMPETING CONSTRUCTION}

The limited availability of construction resources (see Kurtenbach 2014) is central to the tensions between those in disaster-affected areas and the national government's pursuit of the Olympics. In Tohoku, 560 square kilometres of coastline was devastated and the entire region's infrastructure was severely damaged in the 3.11 disaster. The demand for construction in devastated areas combined with demand for Olympics-related construction saw construction costs increase by at least 30\% in 2016 (Japan Property Central 2016), marking the highest cost increase Japan had experienced in this industry since its economic bubble burst in the early 1990s (Nikkei 2014). Given the ongoing need for human security in affected communities, the construction resource battle has put a wedge between the national government's nation-branding/nation-building aspirations and Tohoku identities. As the Mayor of Rikuzentakata, Futoshi Toba, said in 2016: "If construction [of Olympics venues and housing/infrastructure in areas affected by 3.11] overlaps, there won't be enough workers and wages will rise, making houses more expensive" (Lies 2016). ${ }^{11}$ He questioned why the government chose 2020 for the Olympics: "I think they could easily have hosted them four years later" (Lies 2016). In some places-including Kesennumathe delays in obtaining construction resources have compounded difficult living conditions, with one interviewee noting that some evacuees were forced to move from one temporary housing unit to another while waiting for permanent homes to be built (Komatsu 2018). ${ }^{12}$

Rather than embracing a national social imaginary of Japan as a post-recovery Olympic host on the world stage, comments from my interviewees suggest that in Miyagi at least, the Olympic effort is creating a dissonance in the social 
imaginary between those in 3.11-affected areas and Tokyo. For example, Ishinomaki resident Yōko Suzuki (who was a school principal at the time of the 3.11 disaster), understands that the Olympics is significant and meaningful as a global sporting event. However, she cannot see a practical connection to recovery: "It seems to me that 'recovery' is a label attached to the Olympics just for the convenience of politicians. I find it completely intolerable" (2018). ${ }^{13}$ She believes the government should be focusing more on the practicalities of recovery rather than the symbols and meanings of an Olympic pursuit. She makes the point that eight years after the disaster, problems in affected areas of Tohoku remain (2018).

Similar sentiments have been expressed by other regular interviewees from across Miyagi prefecture. "[Hosting the Olympics] may well have some major benefits, but as someone from a disaster-stricken area, I don't think it's going to bring us anything positive" says Shiryū Okano, a resident of Kesennuma and curator at its Rias Ark Museum of Art (2017). ${ }^{14}$ Another Kesennuma resident questions the true meaning of the Olympic efforts. Takashi Tsukamoto, who works in post-disaster community building, says: "[Government and Olympic decision-makers] just slap 'recovery' on the front there-for no real reason [...]. To me this kind of language reveals a major problem: it seems that there is little awareness in national policy or among the people in government that we still need to do a lot more for recovery, rather than just saying that we will show people how much we have recovered already" (Tsukamoto 2017). ${ }^{15}$

Concerns are not only directed towards policy-makers and their rhetoric but also toward representations in the media that fuel misconceptions about what is happening in Tohoku. Okano, for example, feels that the media tends to promote success stories and downplay the massive recovery work that is yet to be done: "The best thing would be to give the people of the world a realistic view of things, to also share some of the outstanding issues-not to paint recovery as a completed picture" (2017) ${ }^{16}$ He makes a further point: "If at the Olympics [the media] just try to make it out like we have already recovered, there would be concern about what would happen afterwards, and people would think the media don't know or care what it's really like up here. It would be a negative step" (2017). ${ }^{17}$ Indeed, he believes that sugar-coating problems would likely frustrate locals and possibly affect what kind of assistance is provided to the area (2017).

A year after the interview with Okano, infrastructure recovery was still underway in Okano's town of Kesennuma, and a representative of the municipality confirmed that around 100 households still remained in temporary housing (Murakami 2018). For Okano, painting a rosy picture 
of the disaster-hit areas in messaging for the Tokyo Olympics has major implications-not only in terms of the kind of assistance that is provided to areas still recovering, but also for affected people's perceptions of their own situation. He is worried that some individuals who are still struggling might feel that everyone else is happy and fully recovered except them (Okano 2017).

Although the national government is deploying the Olympics as a nationbuilding (and nation-branding) tool, the above comments suggest an unintended response. Many in these disaster-affected communities do not feel unity with this particular nation-branding message. Such perspectives demonstrate the limitations of both nation-branding (when human security is undermined) and the 'resilient nationalism' encapsulated in the Ganbarō Nippon slogan. They also provide clues to why the Ganbarō slogan was ultimately localised.

\section{'Ganbarō' Atomised}

In the months that followed 3.11, Ganbarō slogans were widely visible on paraphernalia (posters, stickers, wristbands, bumper stickers, t-shirts, etc.) and through popular and social media. The Ganbarō Nippon catchphrase (discussed earlier) became a rallying cry-a symbol of the support people across Japan hoped to express towards those affected. But as Shani writes, "Slogans such as Ganbarō Nippon rang particularly hollow in the immediate aftermath...for irradiated communities and residents of the tsunami-affected areas who had lost everything to the 'black waters' while political elites were preoccupied with 'containing' the crisis" (Shani 2016, 136). Rather than seeing national unity with Ganbarō Nippon, those in 3.11-affected areas localised the Ganbarō message (Shani 2016, 129-140). In the north, Ganbarō Tohoku ('Let's do our best, Tohoku') was arguably more prolific than the original Ganbarō Nippon. Often Tohoku-oriented Ganbarō paraphernalia aligned with local tropes such as the Pacific League's Tohoku Rakuten Golden Eagles baseball team or with historical figures like Date Masamune, the founder of Miyagi prefecture's Sendai City. As 3.11-affected areas tried to recover, the Ganbarō message further atomised. A person could buy a Ganbarō Matsushima T-shirt at the newly cleared Matsushima port, for example. Town-specific messaging demonstrates how atomised the Ganbarō message became.

As early as April 2011 an Ishinomaki local, Kenichi Kurosawa, created a billboard in the spot where his home once stood. It read, 'Ganbarō! Ishinomaki' (Taylor 2011). Shani reminds us that the localised sign was "a poignant reminder that the isolated fishing villages and farming communities of the north-east and not the 'imagined community' of Japan were the real victims of 3.11" (2016, 136-37). But even the localised sign has been appropriated for wider imagined meanings, to be discussed below.

\section{RESISTANCE}

In the former Kadonowaki-chō school district of Ishinomaki (where the 'Ganbarō! Ishinomaki' sign stands), appropriation and dissonance has grown. 
Even before it was completed, the Ganbarō! Ishinomaki sign became a topic of international news (see Chiba 2011), and it has since become a popular spot on disaster tourism trails. ${ }^{18}$ While ostensibly a symbol of encouragement, the sign can also be seen as a marker of government indifference for those who live nearby, as an interviewee observes. "The mayor has never been here ... hardly any senior officials or politicians have come [to our district]. The only time the mayor comes is if there are dignitaries from overseas. He places a wreath at our Ganbarō sign, visits the primary school ... he only comes when someone like a president visits" (Honma 2014). ${ }^{19}$ This comment came in the context of one community asking its mayor to consider their voices in plans to rebuild the neighbourhood-a request which was initially denied, creating a source of frustration at the time. Eventually, the neighbourhood's energies were exhausted, and the community accepted the neighbourhood rebuilding plan as created by the municipal government-despite the fact that the area's new post-disaster streets lack the social, service and business infrastructure (such as a post office, bank, medical services and convenience stores) that had formerly sustained the neighbourhood (Honma 2016). ${ }^{20}$

Initially, some in Ishinomaki responded to the Olympic pursuit alongside the national government's nation-branding rhetoric, identifying an opportunity. For example, the former neighbourhood of Minamihama on the coast of Ishinomaki (zoned uninhabitable after the disaster due to the tsunami) is to be made into a memorial peace park. Locals envisaged international Olympic visitors making a pilgrimage to the park. Yet by 2014 , this vision was fading. An NPO worker at the time recalls: "As soon as the decision was made to hold the Olympics in Tokyo [September 2013], the trucks started disappearing and the numbers of companies doing [recovery-related] construction decreased" (Kogure 2014). ${ }^{21}$ He confirmed the observation by informally surveying construction company associates he had at the time and reiterated this observation again in 2018, concluding: "There is absolutely no purpose whatsoever for [the government] to be calling these the 'Reconstruction Olympics'. I consider it an outrage" (Kogure 2018). ${ }^{22}$

Already discontented by the national government's inability to provide security during and since the disaster, many in 3.11-affected areas are vocal in opposing the Olympics. Some opposition is expressed via popular and social media. Frustrations are voiced in news stories. ${ }^{23}$ Japanese-language searches on social media using keywords such as 'Tohoku' (東北) and 'Recovery Olympics' (either “復興五輪” or “復興オリンピック’) add more opposing voices. In 2018, the Kahoku Shinpō-a Sendai-based newspaper focussed on the Tohoku region-put numbers behind the idea of an unwelcome Olympics. They surveyed 1,475 people from affected areas, inland areas and wider

18 Disaster tourism, also known as 'dark tourism', refers to the act of visiting/touring places that have been affected by a disaster of some kind.

19 「市長も一回も来たことがないし…上層部、幹部とか政治家もここに来た人はほとんどいません。市長が来る

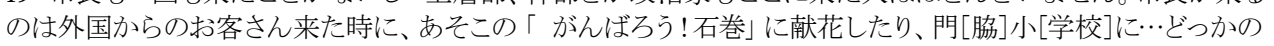
ほら…大統領とか来たときに一緒に来るだけで。」

20 The same mayor officiated at a ceremony to declare the area's reconstruction efforts complete in 2018 (Honma 2018).

21「オリンピックが決まった瞬間からトラックがいなくなっり、引きあげたり、そういう工事をやる、企業さんが少 なくなっています。」

22 「私はまるっきりないと思っていました。名前だけの復興五輪というのが使われるのは心外ですね。」

23 For examples in English, see Alexander (2013), Lies (2016) and Nagano (2016). For Japanese-language

examples, see Kahoku Shinpō (2017), Mainichi Shinbun (2016) and Morita (2017). 
Tohoku, asking the question, "Do you think the 2020 Olympic Games will be useful for the reconstruction of disaster areas?", and published the results. ${ }^{24}$ Across the region, 52\% agreed that it would not be helpful (役に立 たないと思う). The second-largest group comprised 30\% who neither agreed nor disagreed that it would be helpful (どちらともいえない). Only 12\% agreed it would be helpful (役立つと思う), with the remaining 6\% uncertain (わから ない) (Kahoku 2018, 16). Noting that the Tokyo Olympics is being positioned as the 'Reconstruction Olympics', the survey then asked, "Do you think the 'Reconstruction Olympics' philosophy is clear?", to which 63\% responded that it was not (明確ではない) (Kahoku 2018, 17). ${ }^{25}$

Valaskivi notes that "an attempt to portray a particular image towards those outside Japan leads to internal efforts to hide unwanted and uncomfortable elements that do not fit the desired picture" (Valaskivi 2013, 491). As the CJAC has explicitly stated, the events of 3.11 fall into this category (for an example, consider the Creating a New Japan proposal which sought to restore "the shine of the 'Japan Brand"' (METI 2011, 1) in the wake of the disaster). Because these efforts often remain with the elite, they "might even be seen as futile by average citizens, who cannot see any connection between strategy documents and their daily lives" (Valaskivi 2013, 500). This perceived futility is illustrated in the distance between both the 'Recovery Olympics' and Cool Japan images that the national government is trying to foster on the one hand, and the actual social imaginary of 3.11 survivors expressed in the survey and interviews above, on the other. This is reiterated by Suzuki: "They have a feeling that through sports we can make people feel a little bit better and promote Japan's place in the world. Maybe that's what they should be trying to do, but I am pretty sceptical. I would much rather they confronted the realities head-on" (2017). ${ }^{26}$

\section{ABNEGATION}

Presumably to encourage approval of the 2020 Olympic bid, part of the Olympics rhetoric is the notion of having achieved a full recovery. Despite recovery not being achieved, that notion continues-for example, in 2016, Miyagi Governor Yoshihiro Murai was quoted as claiming "[Miyagi prefecture] managed to recover...in just five and a half years" (McKirdy 2016). Around the time of this quote, 150,000 evacuees were still living in temporary housing, including residents of Miyagi prefecture (Reconstruction Agency 2016, 10). An NHK poll of 1,000 survivors on the fifth anniversary of 3.11 observed that $53 \%$ believed "construction is going more slowly than expected" (NHK 2016). ${ }^{27}$ Of those in Murai’s Miyagi, 18\% "see no progress in the reconstruction of their hometown" (NHK 2016). In the Kahoku Shinpō 2018 survey, respondents rated the progress of recovery between $30 \%$ and $70 \%$, indicating that they still viewed the process as ongoing and incomplete seven

24「2020年に行われる東京オリンピックは、被災地の復興に役に立つと思いますか。」

25 「2020年に行われる東京オリンピックは、『復興五輪』との位置づけで誘致されましたが、『復興五輪』の理 念は明確だと思いますか。」

26 「スポーツの力でね、被災地を元気付けようとか、世界に日本の役割、あの、復興した様子を、見せようってい

う思いはあるんだろうけれども、今そういうことをすべきなのかなってのは疑問としてありました。もつと直視して 
As shown earlier, the Ganbarō Nippon initiatives in the immediate aftermath of 3.11 ushered in a 'resilient nationalism' which helped the national government to abnegate responsibility for assistance and recovery, and simultaneously alienated those affected (Shani 2016, 130). For the interviewees quoted above, and the participants in the Kahoku Shinpo survey, the Olympics' recovery rhetoric can be seen to abnegate responsibility in a similar way, by presenting an image of the disaster-hit areas that is at odds with residents' perceptions and experiences.

\section{Community or commodity}

Valaskivi observes that "the very act of perceiving the nation as a brand already changes the social imaginary of the nation as such: a country becomes an object of consumption" (2013,499; italics original). The nation is then "imagined as a commodity, rather than as a community" (Valaskivi 2013, 499). Community (both social and physical) is what people affected by the disaster in Tohoku seek. Commodity is the agenda of Cool Japan strategymakers. This distinction is central to the growing dissonance between those affected by 3.11 and the wider national agenda of political policy makers in Tokyo.

Despite the 2011 rhetoric linking Cool Japan to recovery, the final Cool Japan/ Creative Industries Policy Outline includes little reference to the disaster, or the realities in current-day north-east Japan (METI 2016). Not that it needs to: inbound tourism to the nation has grown, with Japan garnering over 28 million overseas visitors in 2017, compared with just over 6 million in 2011 (JTB Tourism Research \& Consulting Co. 2018). The Japanese government's pursuit of nation-branding projects and attendant rhetoric can therefore be seen as a relative success in the international context. Economic gains may be made by the nation as a whole, but because of competing demands on construction resources any post-Olympic economic gains appear unlikely to speed recovery.

\section{CONCLUSION}

A telling aspect of Abe's performance at the Rio Olympics was how shortlived the ill-fitting Super Mario costume was. Whether by design or error, Abe stood for less than a second before the costume was dramatically ripped off, revealing the truth: a politician dressed in a suit.

Considering Japan's rapidly increasing inbound tourism numbers, slick productions like the one at the 2016 Rio Olympic Games closing ceremony may convince outsiders that Japan is indeed very cool. But the government's pursuit of projects like the Olympics in the wake of 3.11 has effected change 
in the social imaginary and regional ideas of belonging due to a dissonance between those affected by 3.11 and other parts of the nation. There are two main sources of this dissonance. Firstly, concerns exist about the national government's pursuit of the Olympics delaying recovery in Tohoku. Secondly, people from affected areas are disappointed that their calamitous experiences are being deployed under a rhetoric of recovery to promote the event, which to date has had little to no positive impact on their recovery. As an exercise in nation branding, the Cool Japan Olympics are failing to influence a social imaginary in the nation-building context. To this end, Abe's assured smile at the Rio Olympics supported the government's Cool Japan agenda as a transnational nation branding effort. Yet, transfer him from the Rio Olympic arena to the tsunami-inundated and irradiated areas of Tohoku and very different perspectives emerge.

\section{APPENDIX: LIST OF INTERVIEWS}

Honma, E. 2014. Interview by author. Digital recording in Japanese. October 12. Honma, E. 2016. Interview by author. Digital recording in Japanese. June 24.

Kogure, H. 2014. Interview by author. Digital recording in Japanese. October 12. Kogure, H. 2018. Interview by author. Digital recording in Japanese. October 8. Komatsu, T. 2018. Interview by author. Digital recording in Japanese. October 4. Murakami, T. 2018. Interview by author. Digital recording in Japanese. October 4. Okano, S. 2017. Interview by author. Digital recording in Japanese. September 29. Suzuki, Y. 2017. Interview by author. Digital recording in Japanese. October 2. Suzuki, Y. 2018. Interview by author. Digital recording in Japanese. October 10.

Tsukamoto, T. 2017. Interview by author. Digital recording in Japanese. September 29.

\section{REFERENCES}

Abe, S. 2014. "Policy Speech by Prime Minister to the 187th Session of the Diet." Prime Minister of Japan and His Cabinet, 29 September. Accessed 10 January, 2019. https://japan.kantei.go.jp/96_abe/ statement/201409/policyspch.html. Japanese version accessed 14 January, 2019. https://web.archive.org/web/20141013155540/http://www.kantei.go.jp/ jp/96_abe/statement2/20140929shoshin.html.

Aldrich, D. P. 2017. "Trust Deficit: Japanese Communities and the Challenge of Rebuilding Tohoku." Japan Forum (29) 1:39-52. https://doi.org/10.1080/0955 5803.2016.1227350

Alexander, L. 2013. “Tokyo's Win Brings Fear That Tsunami Survivors Will Lose.” The Times, 9 September. http://www.thetimes.co.uk/tto/sport/olympics/article 3864107.ece.

Anderson, B. R. O'G. 1983. Imagined Communities: Reflections on the Origin and Spread of Nationalism. London: Verso.

Berry, J. 2013. "A Uniform Approach? Designing Australian National Identity at the Sydney 2000 Olympic Games." Journal of Design History 26 (1): 86-103. Accessed 29 January, 2019. https://doi.org/10.1093/jdh/eps016. 
Cabinet Office. 2014. Cool Japan Proposal. Accessed 16 January, 2019. https://www. cao.go.jp/cool_japan/english/pdf/published_document3.pdf.

.n.d. Cool Japan Strategy. Accessed 15 January, 2019. https://www.cao.go.jp/ cool_japan/english/index-e.html.

Chiba, Y. 2011. "24 Hours in Pictures." The Guardian, 10 April. https://www. theguardian.com/world/gallery/2011/apr/10/1.

Cleveland, K. 2014. “Significant Breaking Worse.” Asian Studies 46 (3):509-39. https:// doi.org/10.1080/14672715.2014.935137.

Daliot-Bul, M. 2009. "Japan Brand Strategy: The Taming of 'Cool Japan' and the Challenges of Cultural Planning in a Postmodern Age." Social Science Japan Journal 12 (2): 247-66. https://doi.org/10.1093/ssjj/jyp037.

Gamesbids.com. 2011. "Earthquake Topples Tokyo's Olympic Dreams For 2020," Gamesbids.com, 21 March. Accessed June 20, 2018. http://gamesbids.com/ eng/summer-olympic-bids/earthquake-topples-tokyos-olympic-dreamsfor-2020/.

Gutkind, L. 2012. You Can't Make This Stuff Up: The Complete Guide to Writing Creative Nonfiction from Memoir to Literary Journalism and Everything in Between. Boston: Da Capo Press.

IOC (International Olympic Committee). 2018. "Tokyo 2020 Makes Strong Strides Towards Hosting Transformative Games.” Olympic.org, 12 September. Accessed September 19, 2018. https://www.olympic.org/news/tokyo-2020makes-strong-strides-towards-hosting-transformative-games.

Iwabuchi, K. 2015. "Pop-culture Diplomacy in Japan: Soft Power, Nation Branding and the Question of 'International Cultural Exchange." International Journal of Cultural Policy, 21 (4): 419-32. https://doi.org/10.1080/10286632.2015. 1042469.

JTB Tourism Research \& Consulting Co. 2018. "Japan-bound Statistics," JTB Tourism Research \& Consulting Co. Accessed 29 October, 2018. https://www.tourism. jp/en/tourism-database/stats/inbound/.

Japan Property Central. 2016. "Rising Construction Costs are Starting to Affect Building Maintenance." Japan Property Central, 29 March. Accessed June 20, 2018. http://japanpropertycentral.com/2016/03/rising-constructioncosts-are-starting-to-affect-building-maintenance/.

Jiji Press English News Service. 2013. "Warming Up for Tokyo Olympics (5): Philosophy." Jiji Press English News Service, 23 September. Accessed June 20, 2018. http://search.proquest.com/docview/1434875414?accountid=12528.

Kahoku Shinpō [河北新報]. 2017. “Tōkyō kenbun-roku > seika rirē / hisai-chi o dashi gomen kōmuru [東京検分録>聖火リレー/被災地をだしごめん被 る]." Kahoku Shinpō, 16 July. Accessed 22 January, 2019. https://www. kahoku.co.jp/tohokunews/201807/20180716_73032.html. 
2018. 2018 Higashi-nihon daishinsai ankēto [2018年東日本大震災ア ンケート]. 11 March. Accessed 24 October, 2018. https://www.kahoku.co.jp/ img/news/pdf/shinsai_7years.pdf.

Komine, T. 2011. "Viewing the Economic Impact of the Great East Japan Earthquake." Discuss Japan-Japan Foreign Policy 6. https://www.japanpolicyforum.jp/ archives/economy/pt20110603163845.html.

Kurtenbach, E. 2014. "Construction Crunch Slows Japan Tsunami Rebuilding." Washington Examiner, 10 March. http://www.washingtonexaminer.com/ construction-crunch-slows-japan-tsunami-rebuilding/article/feed/2122787.

Lies, E. 2016. "Pain Lingers Five Years on as Tsunami-hit Japan Town Rises From Ruins." Reuters, 9 March. http://www.reuters.com/article/us-japan-disastergrief-idUSKCNOWBOWX.

Lindell, M. K. 2013. "Recovery and Reconstruction After Disaster." In Encyclopedia of Natural Hazards, edited by Peter T. Bobrowsky, 812-24. Dordrecht, Heidelberg, New York, London: Springer. https://doi.org/10.1007/978-14020-4399-4_285.

Martin, B. 2000. "Design Flaws of the Olympics." Social Alternatives 19 (2): 19-23.

Mainichi Shinbun [毎日新聞]. 2016. “Hasshin-bako-fukkō gorin to wa nani ka = Suyama Tsutomu [発信箱- 復興五輪とは何か=須山勉].” Mainichi Shinbun. 26 October. Accessed via Factiva, 21 January, 2019.

McGray, 2002. “Japan's Gross National Cool.” Foreign Policy, May/June: 44-54. https://doi.org/10.2307/3183487. https://foreignpolicy.com/2009/11/11/japansgross-national-cool/.

McKirdy, A. 2016. "Miyagi Governor Bullish on Hosting Olympic Events." The Japan Times, 12 October. http://www.japantimes.co.jp/news/2016/10/12/national/ miyagi-governor-confident-hosting-olympic-events-despite-negativemeeting-organizing-committee/.

METI (Ministry of Economy, Trade and Industry). 2011. Creating a New Japan: Tying Together 'Culture and Industry' and 'Japan and the World'. Accessed 18 June, 2018. https://web.archive.org/web/20110723025619/http://www. meti.go.jp/english/press/2011/pdf/0512_02b.pdf.

2016. Cool Japan / Creative Industries Policy. Accessed 18 June, 2018. http:// www.meti.go.jp/english/policy/mono_info_service/creative_industries/ creative_industries.html.

Morita, H. [森田 浩之]. 2017. “Fukkō gorin’ to iu kotoba ni, nuguikirenai iwakan ga waitekuru [「復興五輪」という言葉に、拭いきれない違和感が湧いてくる].” Gendai Bijinesu [現代ビジネス], 28 July. Accessed 21 January, 2019. https:// gendai.ismedia.jp/articles/-/52408?page=3.

Nagano, Y.2016. "Japan's Desolate Recovery from the Tsunami." U.S. News and World Report, 9 March. https://www.usnews.com/news/best-countries/articles/ 2016-03-09/in-japan-an-incomplete-recovery-from-the-tsunami. 
National Police Agency of Japan. 2018. Police Countermeasures and Damage Situation Associated with 2011 Tohoku District-Off the Pacific Ocean Earthquake, September 10. Accessed October 29, 2018. http://www. npa.go.jp/news/other/earthquake2011/pdf/higaijokyo_e.pdf.

NHK. 2016. "The Great East Japan Earthquake 5 Years On: A Survey of 1000 Survivors," NHK Online. Accessed June 20, 2018. http://www.nhk.or.jp/ d-navi/link/shinsai5/en.html.

Nikkei Inc. 2014. “Japan's Construction Costs at 21-year High.” Nikkei Asian Review, 16 July. Accessed June 20, 2018. https://asia.nikkei.com/Economy/ Japan-s-construction-costs-at-21-year-high.

NAIIC (Nuclear Accident Independent Investigation Commission). 2012. The Official Report of the Fukushima Nuclear Accident Independent Investigation Commission Executive Summary. Accessed 31 October, 2018. http:// dl.ndl.go.jp/view/download/digidepo_3514606_po_NAIIC_report_hi_ res4.pdf?content $\mathrm{No}=1 \&$ alternative $\mathrm{No}=$.

Reconstruction Agency [復興庁]. 2011. Zenkoku no hinansha-tō no kazu [全国の避 難者等の数]]. 24 April. Accessed June 20, 2018. http://www.reconstruction. go.jp/topics/120411hinansya.pdf.

. 2013. Zenkoku no hinansha-tō no kazu [全国の避難者等の数]. 25 October. Accessed January 22, 2019. http://www.reconstruction.go.jp/topics/maincat2/sub-cat2-1/20131025_hinansha.pdf.

2016. The Road to Recovery: Recovery and Reconstruction from the Great East Japan Earthquake. Accessed June 20, 2018. http://www.reconstruction. go.jp/english/topics/Progress_to_date/pdf/201609_The_Road_to_ Recovery_E.pdf.

2017. Zenkoku no hinansha-tō no kazu [全国の避難者等の数]. 28 March. Accessed June 20, 2018. http://www.reconstruction.go.jp/topics/main-cat2/ sub-cat2-1/20170328_hinansha.pdf.

. 2018a. Zenkoku no hinansha-tō no kazu [全国の避難者等の数].” 29 May. Accessed June 20, 2018. http://www.reconstruction.go.jp/topics/main-cat2/ sub-cat2-1/20180529_hinansha.pdf.

. 2018b. Zenkoku no hinansha-tō no kazu [全国の避難者等の数].” 28 September. Accessed October 29, 2018. http://www.reconstruction.go.jp/ topics/main-cat2/sub-cat2-1/20180928_hinansha.pdf.

Samuels, R. J. 2013. 3.11: Disaster and Change in Japan. Ithaca: Cornell University Press.

Shani, G. 2016. "Ganbarō Nippon: Human Insecurity, Resilience and National Identity After 3.11." In The Consequences of Global Disasters, edited by A. Elliott and E. L. Hsu, 129-40. Abingdon and New York: Routledge.

Taylor, A. 2011. "Japan Earthquake: The Long Road to Recovery." The Atlantic, 15 April. Accessed 29 October, 2018. https://www.theatlantic.com/ photo/2011/04/japan-earthquake-the-long-road-to-recovery/100047/. 
Taylor, C. 2004. Modern Social Imaginaries. Durham: Duke UP. https://doi. org/10.1215/9780822385806.

TMG (Tokyo Metropolitan Government). 2016. See you in Tokyo and Tohoku 2020. YouTube video, posted 27 April. Accessed October 24, 2018. https://www. youtube.com/watch?v=DVzUf2lW3wk\&feature=youtu.be.

. 2018. See you in Tokyo and Kumamoto 2020. YouTube video, posted 18 February. Accessed October 24, 2018. https://www.youtube.com/ watch?v=o2UJL2vxU-I\&feature $=$ youtu.be.

Tomlinson, A. 2014. "Olympic Legacies: Recurrent Rhetoric and Harsh Realities." Contemporary Social Science 9 (2): 137-58. https://doi.org/10.1080/21582041 .2014.912792.

United Nations. 2005. Resolutions Adopted by the General Assembly A/RES/60/1. Accessed June 20, 2018. http://www.ifrc.org/docs/idrl/I520EN.pdf.

Valaskivi, K. 2013. "A Brand New Future? Cool Japan and the Social Imaginary of the Branded Nation." Japan Forum 25 (4): 485-504. https://doi.org/10.1080/ 09555803.2012.756538.

Willacy, M. 2013. Fukushima: Japan's Tsunami and the Inside Story of the Nuclear Meltdowns. Sydney: Pan Macmillan.

Wilson, J. 2016. Rio 2016: Closing Ceremony. Television broadcast, Channel 7 (Australia). 22 August. 


\section{Wetland Restoration in Japan: What's Law Got to Do with It?}

\author{
EVAN HAMMAN \\ Queensland University of Technology
}

\section{ABSTRACT}

Decades of destruction, land reclamation and pollution have wreaked havoc upon Japan's wetland environments. The government has responded by implementing new laws and policies that seek to reverse the declines by encouraging the involvement of the local community and NGO sector. At the same time, the government has also engaged with international and regional frameworks such as the Ramsar Convention and the East Asian-Australasian Flyway Partnership. This paper explores the interrelationship between Japanese law, international law and a 'restoration ethos' in Japan. It argues that the Japanese government's desire to restore the natural environment is ably supported by a legislative and policy framework which draws upon best practice in collaborative governance. By focusing on wetland restoration, the paper sheds light on the connections between local, national and international stakeholders. Wetlands provide important habitat for biodiversity (especially birdlife) as well as filtration and sediment control, and act as a natural buffer against disasters. Japan appears well-placed to reverse the declines in wetland health, although more needs to be done to reconnect with traditional socioecological landscapes such as satoumi and satoyama.

\section{KEYWORDS}

Act for the Promotion of Nature Restoration; birdlife; birds; collaborative governance; conservation; East Asia; ecological restoration; endangered species; international law; law; Ramsar Convention; wetlands

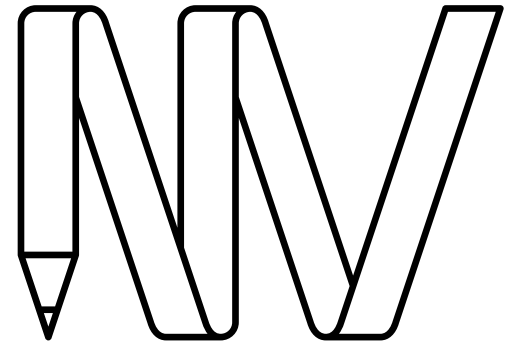

NEW

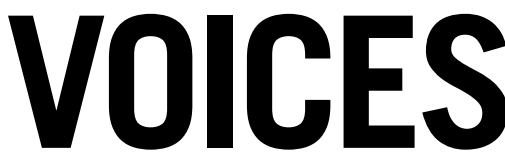

IN JAPANESE STUDIES

JAPANFOUNDATION \&

BRINGING JAPAN TO YOU

To link to this article:

https://doi.org/10.21159/nvjs.11.03

\section{ISSN 2205-3166}

New Voices in Japanese Studies is an interdisciplinary, peer-reviewed journal showcasing the work of emerging scholars with ties to Australia or New Zealand and research interests in Japan.

All articles can be downloaded free at newvoices.org.au

(c) The Japan Foundation, Sydney and Evan Hamman, 2019

\section{(c) $(1)$}

This work is licensed under a Creative Commons Attribution-NonCommercialNoDerivatives 4.0 International License. 
As in many parts of the world, Japan's wetlands are in decline (Davidson 2014). Land reclamations, agricultural drainage and pollution have dangerously disrupted the aquatic ecosystems on which Japan depends (Nakamura et al. 2006). Reclamation of tidal wetlands in Tokyo Bay and the Ariake Sea has been particularly debilitating for migratory shorebirds which rely on the mudflats for food in their long journeys from their breeding grounds in the north of Asia to their wintering grounds in the southern hemisphere (Ichikawa et al. 2017). The driver of much of this has been the relentless economic growth that Japan has pursued since the end of World War II. In the 1970s and 1980s, the mantra of "develop now, clean up later" was very much at the forefront of government thinking (Nakamura et al. 2006, 420). Roads, bridges, airports, industrial sites and even theme parks were all constructed with little or no concern for the environmental impacts and with few, if any, legal protections in place.

Since the 1990s, however, Japan has made a noticeable shift towards the 'restoration' of its wetlands. One of the turning points was a major wetlands conference held in 1993 in Kushiro, Hokkaido. The Kushiro Conference of the Parties (hereafter, 'the Kushiro COP') helped solidify Japan's place as one of the key players under the Ramsar Convention (hereafter, 'Ramsar'), the main international treaty that governs wetland conservation. ${ }^{1}$ At the Kushiro COP, Japanese non-government organisations (NGOs), ornithologists and bird enthusiasts were all integral in bringing the state of Japan's wetlands to the attention of the international community. Since then, environmental groups like Wetlands International (国際湿地の日本支部), Ramsar Network Japan (ラムサール・ネットワーク・ジャパン), Birdlife International (バードライフ・インタ 一ナショナル 東京) and the Wild Bird Society of Japan (日本野鳥学会) have advocated for more explicit and effective strategies on wetland conservation in Japan. With Ramsar Network Japan at the forefront, NGOs in Japan are pushing the Japanese government to designate a total of 100 Ramsar sites by 2030 (Ramsar Network Japan 2015). The MOEJ has officially adopted a more modest goal of 10 new sites to be designated between 2012 and 2020 (MOEJ 2012,142 ), but while only 8 new sites have been designated since 2012, other actions suggest that it may be open to further increasing designations in the future. $^{2}$ As at 2019, Japan has 52 Ramsar sites, with Kushiro wetlands the first site listed in 1980 (for a map of Ramsar sites in Japan, see Figure 1).

\footnotetext{
1 The Ramsar Convention on wetlands of international significance is the most important convention on wetland environments. It has been widely ratified, including by Japan. The Convention is often referred to as the Ramsar Convention, named after the Iranian city of its signing in 1971. Every three years, the nations that have signed the Convention meet to resolve the listing of wetland sites of international importance and discuss mechanisms for conservation and restoration. These meetings are known as 'Conferences of the [Ramsar] Contracting Parties' or 'COPs'. The main participants at COPs are delegates from the signatory nations, although there are many NGOs that also attend and host side events, share knowledge and run capacity-building sessions. The resolutions decided upon after each COP can be found on the Ramsar Convention Secretariat's website: https://www. ramsar.org/about/the-conference-of-the-contracting-parties. The designation process for listing wetlands of international importance in Japan (i.e., Ramsar sites) is outlined later in the paper. Definitions of specialist terms such as those outlined here are collated in a glossary at the end of this paper. A bilingual list of Japanese and international environmental governance frameworks cited in this paper is provided in Appendix 1.

2 As Ramsar Network Japan (2015) notes, "although the position of the [MOEJ] in 2005 was that about 50 Ramsar sites might be the upper limit, they announced as many as 172 candidate sites in September 2010. 


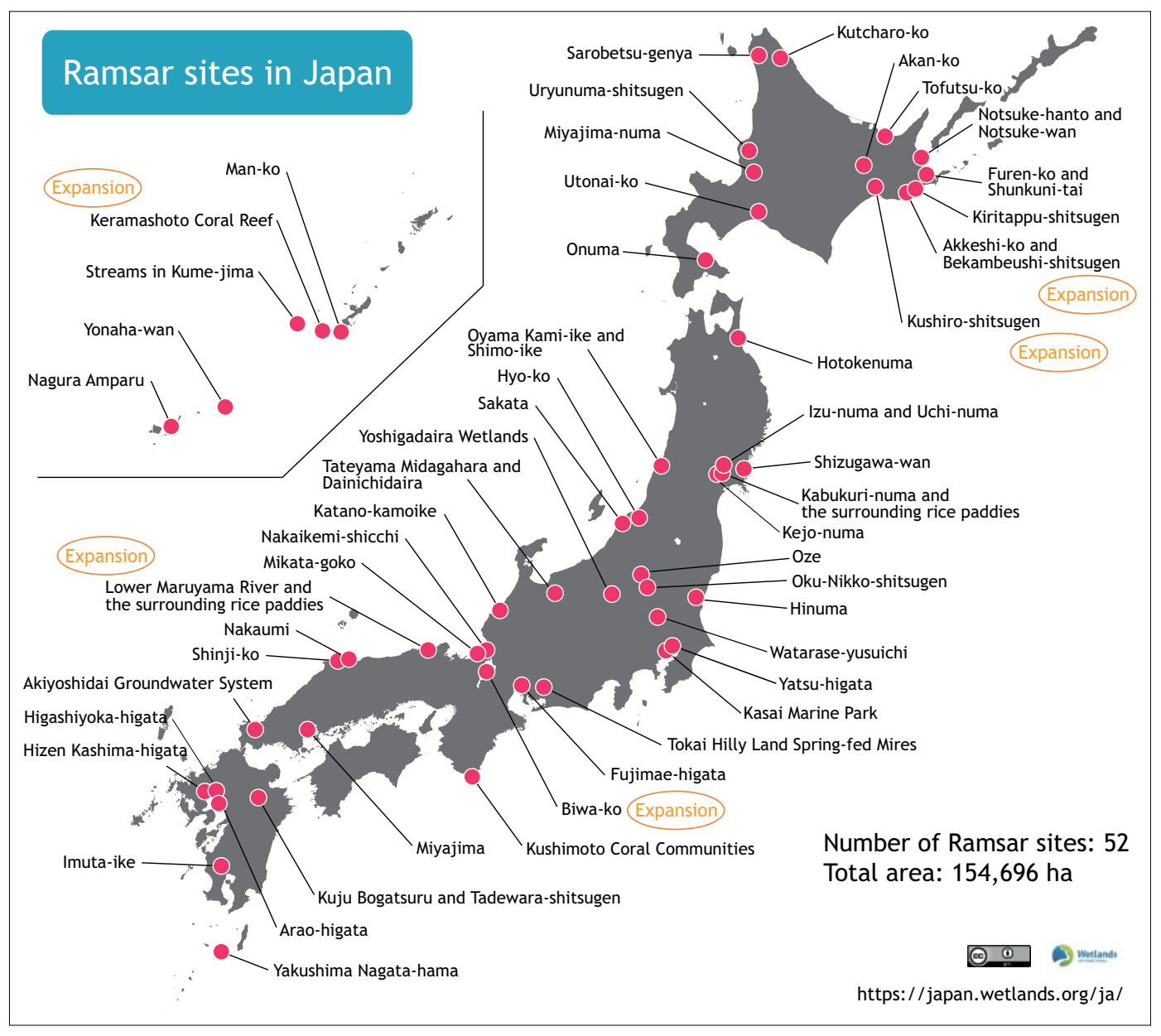

Figure 1: Ramsar Sites in Japan (as at May 2019)

Source: Wetlands International Japan (CC-BY).

This paper examines the role that law and culture have played, and should play, in the conservation and restoration of Japan's wetland environments. It argues that Japan's efforts to establish the institutional and legislative architecture necessary to drive wetland governance are supported by a 'restoration ethos' that can also be found in other examples of Japanese law. There are few examples around the world of law and culture intersecting in this way, and there is perhaps much that can be learned from the Japanese example. In addition to highlighting the relationships between Japan's environmental law and other domestic legislative instruments, the paper also shows-with a focus on wetland environments-how Japan's nature restoration frameworks simultaneously scaffold collaboration at both local and international levels. This is achieved through intersections with domestic legislation and international environmental governance frameworks on one hand, and through activation of the local government and NGO sectors on the other.

The paper is structured in three parts. Part one provides background to Japan's wetland environments, noting their significance as habitat for biodiversity as well as for agriculture, and highlighting the decline of Japan's wetlands largely due to coastal reclamation and rice paddy conversion. 
Part two introduces the concept of 'ecological restoration', drawing a link to a broader philosophy of 'recovery' or 'healing' in Japan referred to in this paper as a 'restoration ethos'. Part two also analyses the 2002 Act for the Promotion of Nature Restoration (自然再生推進法; hereafter, 'Nature Restoration Act'), and notes that Japan stands out as one of only a handful of nations to have passed legislation that aligns with the ecological restoration concept. Close to a dozen projects have been initiated under this law in Japan to date, and this part of the paper provides examples of those that relate to wetland environments. Finally, part three of the paper charts a path towards improved restoration efforts in Japan. It argues for a deeper connection with 'socio-ecological production landscapes' and highlights the importance of well-planned community engagement.

\section{WETLANDS IN JAPAN}

\section{What is a Wetland?}

The term 'wetland' ('湿地' in Japanese) is challenging to define. There is currently no formal definition under Japanese law as, unlike other Asian nations like South Korea and Taiwan, Japan lacks targeted national wetland legislation. A basic definition is likely to cover any land environment which at one time or another is submerged or partially submerged under water. Obvious inclusions in this definition are lakes, mangroves, peatlands and marshes. In a study of Hokkaido's wetlands, Fujita et al. (2009) defined wetlands as areas greater than one hectare "with natural vegetation under wet conditions such as mire (peatland), river flood plain, lakeshore, and seashore" (12). Japan's national biodiversity policy describes wetlands as a type of "inland water ecosystem" (MOEJ 2012, 45) although it stops short of ascribing a more detailed descriptive label to them.

Under Article 1.1 of the Ramsar Convention, wetlands are defined as:

areas of marsh, fen, peatland or water, whether natural or artificial, permanent or temporary, with water that is static or flowing, fresh, brackish or salt, including areas of marine water the depth of which at low tide does not exceed six metres.

Notably, Ramsar's definition (which is adopted in this paper) includes both natural and artificial sites. Accordingly, Japan's rice paddies might be classified as wetlands under international law. Indeed, rice paddies have become a vital component of the natural environment in Japan as habitat for waterbirds. There is considerable scientific evidence that bird species such as the Oriental Stork (Ciconia boyciana; コウノリリ) and Japanese Crested Ibis (Nipponia Nippon; トキ) thrive in rice-farming landscapes (Takahashi 2009, 1960). ${ }^{3}$ In fact, as Fujioka et al. (2010) have found, almost a third of Japan's bird species can be found in its rice paddy environments at some point in their life cycle. ${ }^{4}$ 
The manner in which wetlands are conceived has important ramifications for their effective conservation and wise use. Wetlands can and should be distinguished, for example, from other water-based environments such as river systems and the marine environment. Narrowing in on exactly what wetlands are allows for a more sophisticated understanding of their conservation needs, their hydrological inputs and outflows, and, ultimately, what an effective legislative and institutional policy response to their declines might look like.

\section{Distribution and Ecology}

Japan is a country of extraordinarily high rainfall (MOEJ n.d.[a]), particularly during the summer months, owing largely to the influence of the Asia monsoon (Mo et al. 2005, 82). It is also a nation which relies heavily on its rivers, wetlands and other aquatic environments for domestic consumption, commercial usage and rice cultivation (Haidary et al. 2013). Japan's rivers (of which there over 14,000) are classified as either 'class A', 'class B', 'secondary' or 'regular' depending upon their size and importance to the national government (Nakamura et al. 2006, 421). Japan has 109 'class A Rivers'-that is, rivers seen to be of crucial national importance, and which are owned and managed by the national government (Nakamura et al. 2006).

Japan's river systems support a wide variety of flora and fauna. Whilst Japan would not be classified as 'mega[bio]diverse' in the same way as Indonesia, the Philippines, Australia or China would (Mittermeier et al. 1997), it is still home to over " 160 species of mammals, 700 species of birds, 30,000 species of insects and 7,000 species of vascular plants" (MOEJ n.d.[a]). Japan's wetlands and woodlands in particular support the majority of its bird species. However, many of Japan's birds are migratory, and hence their survival relies heavily on what is happening elsewhere in the region, especially in China, Russia, Indonesia, South Korea, North Korea, Australia and the Philippines. All of these nations (and several others) have signed a regional agreement known as the East Asian-Australasian Flyway (EAAF) Partnership which seeks to conserve migratory waterbirds through management of the wetland areas they rely on. ${ }^{5}$ As a founding member, Japan currently has 33 'flyway sites'the most out of any nation in the Partnership.

In terms of variety of wetlands, Japan is home to marshes, tidal flats, coral reefs, mangroves, seaweed beds, rice paddies and reservoirs. Its tidal mudflats, known as higata (干潟) in Japanese, are areas of particularly rich and unique biodiversity. Japan's higata provide habitat for a variety of mud-dwelling organisms such as crabs, worms and sponges, which in turn attract the presence of hundreds of thousands of migratory waterbirds annually. Most of Japan's important higata are found in estuarine environments-that is, at 
the mouths of rivers-such as where the Tama River flows into Tokyo Bay, the Fushino River into Yamaguchi Bay, or where the Shiota and Kashima Rivers meet in the Ariake Sea. Japan's Ariake Sea in particular is biologically rich; this has been attributed to its temperate climate, considerable tidal variation and the presence of shoals which help to facilitate sediment deposition (Ramsar Sites Information Service 2015, 2).

\section{Declines and Threats}

While the story of Japan's post-war economic growth is well-documented, the impacts on its wetland environment are perhaps less well-publicised. The reclamation and drainage of Japan's wetlands, primarily for rice farming but also for port and urban development, is not a new phenomenon. In fact, Japan has a long history of degrading its wetlands (Dempster 1967, 150; Koh and De Jonge 2014). As Eyre (1956) points out, evidence of paddy reclamation in Kojima Bay (Okayama prefecture) can be traced back to the 1570s. Moreover, much of the city of Tokyo (previously, Edo) was constructed directly upon or adjacent to wetland environments (Ichikawa 1994; Hong and Iisaka 1982). Whilst early impacts of cities on wetlands were gradual given the limited nature of machinery, the "introduction of the bulldozer" in 1950 hastened the destruction of many wetland environments (McCormack 1996, 95). Satellite imagery, for instance, has shown the increased loss of tidal areas in Tokyo Bay during the 1970s and 1980s (Hong and Iisaka 1982; Endoh 2004), and this loss continues today, including in built up areas such as Haneda airport (Watabe and Sassa 2016).

The statistics paint a distressing scene. Up to $40 \%$ of Japan's higata are estimated to have been destroyed in the fifty years since the end of World War II (Shimba 2007, 11; MOEJ 2012, 46). On the island of Hokkaido, up to 70\% of original marshlands have been lost to agriculture (Fujita et al. 2009, 10). Further, reclamations along Japan's coastline have also been considerable. MOEJ estimates that about one-third of Japan's entire $32,800 \mathrm{~km}$ coastline could now be classified as 'artificial' (MOEJ n.d.[b]). However, reclamations and rice paddy conversions are not the only concern. Water pollution from nutrient loading and pesticides on farms has also had severe impacts, and so too has 'point source' pollution from industrial and chemical factories. Totman (2014) observes, for example, that much of the wetland degradation has been "accomplished through liquid waste" (510) from industrial sources. Nakamura et al. (2006) concur, writing: "the economic boom between 1950 and 1970 caused severe water pollution throughout the country" (420). These problems have either removed entirely or negatively affected the ecological character of many of Japan's wetland sites, hampering their capacity to act as buffer and filtration systems within the broader natural landscape.

Suffice it to say, the flow-on effect to Japan's biodiversity has been enormous. The declines are most clearly evidenced by the drop of migratory bird populations in Japan (Amano et al. 2010). Populations of waterbird species like the Dunlin (Calidris alpina; ハマシギ) have declined rapidly in recent years 
(Zöckler et al. 2003). As Ichikawa et al. (2017) report, in the past forty years, shorebird populations have "decreased drastically" across the nation (344). Asia's shorebirds are a group of waterbirds that breed in Alaska and Siberia and spend the winter in places like Japan, China, Australia and Korea. Numbers of the Eastern Curlew (Numenius madagascariensis; 木 ウロクシギ)—a passage migrant in Japan, and the largest shorebird in the world-have declined by up to $80 \%$ in three generations (EAAF Partnership n.d.). ${ }^{6}$ The Eastern Curlew is now listed by the International Union for the Conservation of Nature as "endangered", the second-highest threat category available before extinction (Birdlife International 2017).

Of course, the problems of declining waterbirds and wetland degradation are not unique to Japan. Other nations in Asia (South Korea and China in particular) have rapidly lost their wetlands due to agriculture and port development (Murray et al. 2014). China's Yellow Sea coast, including the Bohai Gulf, has become the new frontier in the fight to save Asia's waterbirds (Murray et al. 2014; Hamman 2018). The coastal mudflats of the Yellow Sea are the main staging and refuelling site for many hundreds of thousands of migratory waterbird species along the EAAF (Murray et al. 2014). However, rapid industrial development over recent decades has seen marked degradation and decline of its intertidal flats, which is heavily impacting upon the future survival of Asia's migratory birds. Accordingly, the outlook is presently dim for waterbird species across the region. Against this background, the next section of the paper discusses the relevance of international and domestic law in conserving and restoring Japan's wetland environments.

\section{Japan and the Ramsar Convention}

The Ramsar Convention is an international treaty which provides for the identification and conservation of wetlands of 'international significance'. Along with the Convention on Migratory Species, the Convention on Biological Diversity and the World Heritage Convention, Ramsar is one of the most important international environmental agreements. Ramsar currently has 170 member countries and a total of 2,326 Ramsar sites covering 250 million hectares. Although Japan joined Ramsar in 1980, it was not until the 1990s that it emerged as a major player in wetland conservation. Since then, the Japanese government has appeared to embrace Ramsar's programs such as 'Wise Use of Wetlands' and 'Community Education Participation and Awareness'. Japan's alignment with Ramsar (at least on paper) stands in contrast to its refusal to sign other international laws such as the Convention on Migratory Species due to its strong position on hunting of migratory whales.

As at May 2019, Japan's 52 Ramsar sites place it eighth in the world-behind only the United Kingdom (175 sites), Mexico (142), Spain (75), Sweden (68), Australia (66), Italy (56) and the Netherlands (55) - in terms of the number of internationally recognised wetlands it oversees. The designation of a Ramsar site usually occurs after a site has been declared a 'Wildlife Protection Area' 
or 'Special Protection Area' by the national government (Fletcher et al. 2011, 958). To meet the criteria for a Ramsar site, a nomination must be made by the national government. However, in Japan, Ramsar nomination is complicated by a domestic process which requires local government approval before a wetland can be designated as a Ramsar site (Asano 2014, 52). Therefore, in practice, Ramsar nomination in Japan is largely dependent upon grassroots action, initiated by local governments with the help of wetland NGOs and bird conservation groups.

Fletcher et al. (2011) point out that the "brand" of Ramsar appears to be strong in Japan (958), and empirical evidence points to a certain degree of government effort to implement the overall conservation goals and objectives of Ramsar. The national government, for example, has established a special committee for the implementation of Ramsar (Ramsar Convention Secretariat 2014). As Asano (2014) notes, Ramsar has provided "a catalyst for constructing new relationships between residents and nature" in Japan, particularly around wetland education (61).

\section{National Wetland Policy}

Japan's approach to the Ramsar Convention is also reflected in a sophisticated biodiversity conservation framework at the national level. Whilst there is still no national wetland law in Japan, the MOEJ has created a national wetland policy which forms part of the National Biodiversity Strategy 2012-2020 (日本 の生物多様性国家戦略). At over 300 pages in length, the National Biodiversity Strategy is an ambitious and far-reaching document. It seeks to establish a "roadmap" towards the establishment of "an enriching society" which works "in harmony with nature" (MOEJ 2012, 1). The pursuit of a human-nature connection as articulated in this policy can be seen as consistent with the government's Wanokuni Zukuri sustainability initiative, originally proposed in 2001 (Onodera et al. 2007, 100). ${ }^{7}$ The underlying objective of the initiative at the time was to formally recognise a "harmony" between the Japanese people and their natural environment and make "active efforts" in the restoration of nature (Onodera et al. 2007, 100). It should be noted that this is not unique to Japan: government strategies to promote people living in harmony with nature also exist elsewhere in Asia, most notably in China's efforts to (re)establish an 'ecological civilisation' (Barresi 2017).

The conservation of Japan's rivers and wetlands are referred to in detail in Section 8 of the National Biodiversity Strategy, although tidal mudflats are covered separately in Section 9. The National Biodiversity Strategy singles out tidal wetlands as special areas of concern for the MOEJ. The strategy explicitly acknowledges that many tidal flats and coastal wetlands have been lost through over-development in the post-war era (MOEJ 2012, 30). This has led directly to the decline of organisms living in the tidal zone such as the Japanese Horseshoe Crab (Tachypleus tridentatus; カブトガニ) and the 
Fiddler Crab (Uca arcuata), known in Japanese as shiomaneki (シオマネキ; lit., 'beckoning the return of the tide'). Both the Japanese Horseshoe Crab and Fiddler Crab are now on Japan's endangered species list (MOEJ 2012, 46; Wada et al. 2016). As alluded to above, the decline of these organisms and the loss of the mudflats more generally has contributed to population decline amongst Japan's migratory waterbirds.

More relevantly for the purposes of this paper, the National Biodiversity Strategy also encourages the government and communities to embrace the concept of nature restoration. ${ }^{8}$ The National Biodiversity Strategy sets out a clear vision for addressing decline in coastal and near-shore environments in Japan "through restor[ing] the connection between people and the sea and the rich biotas that are inherent in coastal areas" (MOEJ 2012, 73). Under the National Biodiversity Strategy, which notably utilises the word "restoration" in addition to "conservation" (e.g., MOEJ 2012, 73), over two dozen major wetland restoration projects have already begun in Japan, in places like Fushino River in Yamaguchi prefecture and Kushiro River in Hokkaido (Onodera et al. 2007, 106). Not all restoration projects have been wetland projects, but they often involve a major river or aspect of a river system. Those relating to wetlands are outlined in Appendix 3.

The reference by the MOEJ to 'restoration' in addition to 'protection' and 'conservation' is deliberate. Whereas 'conservation' seeks to maintain the status quo of an ecological system, 'restoration' is far more forward looking. Arguably, this distinction forms a major component of the Japanese government's vision (or at least its rhetoric) of creating harmony between people and nature. A short extract from the National Biodiversity Strategy which demonstrates this is worth reproducing here in full:

Towards the establishment of a society in harmony with nature, it is necessary to renew our appreciation of the value of the natural environment and promote efforts to conserve the natural environment including the flora, fauna and ecosystems endemic to local areas. In addition, it is also necessary that we revive the local natural environment through nature restoration, in an effort to create local communities which can benefit from nature.

(MOEJ 2012, 147)

The restoration commitments made in the National Biodiversity Strategy above do not exist in a policy vacuum. As the next section of this paper shows, they are supported by a broader framework of domestic law and governance around restoration in various contexts in Japan. Earlier legislative initiatives such as an amendment to Japan's River Act (河川法) in 1997 and the introduction of an NGO promotion law in 1998 preceded the 2002 passage of the Nature Restoration Act. As Telesetsky et al. (2017) note, targeted legal arrangements to enable restoration are rare in the world of environmental governance. Aronson et al. (2011) concur, stating that only a handful of nations, including Brazil, South Africa, Namibia, Ecuador, Costa Rica, Vietnam and India, have enacted "public policy and detailed legislation on restoration...[in order to] promote, reward, or enforce 
restoration of degraded ecosystems" (692). Accordingly, Japan is amongst a select group of nations seeking to use law as a tool for encouraging restoration and recovery of its environment. The next section of this paper aligns this move with a possible broader philosophy of recovery and restoration in Japan.

\section{RESTORATION IN JAPAN}

\section{A Restoration Ethos?}

As a nation frequently impacted by earthquakes, typhoons and tsunamis, the idea of restoration could well be said to have become part of Japan's DNA. In its literal translation, 'restoration' (再生) refers to the act or actions of bringing something back to life-for example, by recreating or re-enacting it. Rapid advances in technology have allowed Japan, as it has other nations, to 'recreate' its lost built heritage, damaged as it may have been through war or natural disasters. Some examples of this kind of recovery in Japan, at least in modern times, are its reconstruction efforts after World War II, and its efforts to rebuild cities and towns after natural disasters such as the Great East Japan Earthquake in the Tohoku region (2011) and the Great Kanto Earthquake, which struck Tokyo and surrounds in 1923. ${ }^{9}$ Totman (1989) also describes the way in which the Japanese have mended their relationship with forests in the landscape, noting how periods of considerable deforestation have been followed by state-led initiatives of replanting and recovery. ${ }^{10}$

The interrelationship between law and policy on the one hand, and Japan's experience with restoration on the other, presents an interesting perspective to consider. There is evidence, for instance, that law and a desire for restoration have merged in Japan in some cases. For example, national-level laws have been passed in Japan such as the 2011 Basic Act on Reconstruction in Response to the Great East Japan Earthquake (東日本大震災に対する復興基 本法; hereafter, 'Tohoku Reconstruction Act') which make specific reference to restoring damaged communities and the provision of 'security'. Passed after the Tohoku earthquake (the largest recorded earthquake ever to hit Japan) and resulting tsunami, the law aims to:

create safe communities where preventive measures against damage due to earthquakes and other natural disasters are effective and everyone can enjoy a sense of security for years and decades to come.

(Article 2(v)(a)).

According to Takeuchi et al. (2015), the Great East Japan Earthquake "brought about a major turning point in the question of how to rebuild the relationship between people and nature" (31). This can be seen in the Tohoku Reconstruction Act, which represents not only a legal framework for the

9 It should be acknowledged that there is an ongoing debate around 'recovery efforts' related to the Great East Japan Earthquake in the Tohoku region, as many thousands of evacuees are still in temporary housing. The unintended impact of one government-led reconstruction initiative related to the 2011 earthquake is briefly discussed later; however, a thorough critique or examination of recovery efforts following such a monumental disaster is well outside the scope of this paper. For further reading on recovery following the Great East Japan Earthquake, especially related to governance responses, see Cho (2014). 
mobilisation of government resources, but a broader objective to prevent damage to the physical (built) world and reconsider the relationship between Japan and the natural environment.

A year after the Tohoku Reconstruction Act was enacted, a similar initiative was implemented entitled Special Measures for the Reconstruction and Revitalisation of Fukushima (福島の復興と活性化のための特別措置). The measures aimed, amongst other things, to "facilitate the reconstruction and revitalisation of Fukushima following the nuclear disaster, by establishing basic guidelines for reconstruction and revitalisation of Fukushima" (Article 1). That the language of restoration and revitalisation was included in such laws arguably reflects an ethos of restoration and recovery at the highest levels of government.

\section{Ecological Restoration}

The restoration of the natural world, referred to elsewhere in the literature as 'ecological restoration' (see Telesetsky et al. 2017, 17), brings with it complexities that are different from the built environment. Ecological restoration can be defined as "intentional activity that initiates or accelerates the recovery of an ecosystem with respect to its health, integrity and sustainability" (SER $2004,1)$. This is a similar, although probably not identical, concept to the idea of 'nature restoration' that Japan has promulgated through its recent laws and policies as set out in this paper. The major difference is that the Japanese government does not adopt the terms 'ecosystem' or 'ecology' but instead prefers the term 'nature'.

Semantics aside, there are often complicated value-laden questions surrounding the scale and timing of ecological/nature restoration which first need to be answered (see Akhtar-Khavari and Richardson 2019). These include, for example: what aspects of the environment need to be restored, by whom, and to what ends? The last part of this question raises considerable difficulties for decision-makers. Unlike the reconstruction of a building, for example, adequate resourcing and technology is not always the primary consideration. Attributes and appearances of structures have a fixed point in time to which they can be 'restored'. For example, the revitalisations of Japan's famous castle complexes (e.g., Osaka Castle, Nagoya Castle) reflect Japan's ability to recover its built heritage to a particular point in time. The natural world, on the other hand, is a far more fluid and illusive construct. There is no start or end point to nature, and contemplating a time when an ecosystem was 'healthy' or 'productive' is open to considerable debate.

Despite these challenges, the pursuit of the restoration of nature across the world is not a new phenomenon (Akhtar-Khavari and Telesetsky 2016, 51). Even in Japan, there is some history of attempts to restore rivers, estuaries, rice paddies and other environments (Nakamura et al. 2006, 419). Much of this began in the 1990s, and tended to focus on the recovery of rivers as opposed to other (lesser known) wetland environments like mudflats, marshlands and coral reefs. Between 1990 and 2005, over 23,000 river restoration projects 
were initiated in Japan (Nakamura et al. 2006). These projects were supported by a 1997 amendment to the national River Act (河川法), which provided a formal justification for "improvement of the river environment" (Nakamura et al. 2006, 421). The newly amended River Act, however, had little relevance for the recovery and restoration of tidal flats, marshlands and coral reefs: the river environment, it seems, was the primary focus of Japan's first major policy to recover damaged water-based environments (Nakamura et al. 2006, 421).

More recently in Japan, however, there have been examples of targeted wetland restoration (as opposed to simply river improvement) which have sought to benefit both humans and biodiversity (Tsujii and Sasagawa 2012). Most of the larger wetland projects have been initiated under the Nature Restoration Act (discussed in detail below), which was established five years after the River Act and put wetlands on centre stage. As Nakamura et al. (2006) write, the Nature Restoration Act calls for "a sound scientific underpinning for restoration projects [and] has stimulated countless restoration projects throughout [Japan]," including in relation to wetlands (421).

Many localised wetland restoration projects in Japan now relate to rice paddy environments, which are perhaps the clearest examples of human-biodiversity connections. Indeed, most of these have been initiated or heavily supported at a local level by farming communities and local governments (Tsujii and Sasagawa 2012). For example, in Miyagi prefecture's Osaki City, a method of farming known as fuyumizu-tambo (冬水田んぼ; lit., 'winter water rice field') - which involves submerging rice fields throughout the winter offseason-encourages farmers to cultivate rice without any chemical pesticides or fertilisers. Where fuyumizu-tambo is not practiced, rice paddies are drained in the winter months to encourage nitrogen in the soil; this practice has the effect of killing microorganisms and deterring visiting birdlife (Tsujii and Sasagawa, 2012, 6). In contrast, where fuyumizu-tambo is practiced, paddy wetlands are 'restored' by allowing water to remain in the paddies through both summer and winter, at the same time providing additional habitat for over 130,000 migrating geese to Miyagi each year (Tsujii and Sasagawa 2012, 6).

From a governance perspective, it is advantageous for these types of restoration projects (for wetlands, rivers or otherwise) to be supported by law. Passing laws which allow for restoration has the advantage of controlling practical issues such as insurance, financing, provision of machinery, transparency in decision-making, and issuing of permits (to enter private or public land). The law can also set out basic principles or objectives for how the restoration is to occur. A good example of a law created specifically for ecological restoration is that of Japan's Nature Restoration Act, introduced above and covered in more detail in the next section.

\section{Act for the Promotion of Nature Restoration (Nature Restoration Act)}

Japan's Nature Restoration Act (2002) aims to encourage restoration of the natural environment. There is an accompanying policy to the law which sets out further detail to the government's approach (MOEJ n.d.[c]). Before the 
law was passed in 2002, there was disagreement amongst Japanese politicians about what exactly it should seek to achieve. As Onodera et al. (2007) recall, "the biggest argument was [whether] nature restoration was just another public project [in Japan] with a different name" (111). In Japan, as elsewhere, laws have the effect of binding government decision-makers to ensure that their actions are accountable through the courts. Accordingly, it has been argued that the passage of a nature restoration law in Japan will help to ensure "nature restoration projects [form] a solid movement for years to come" (Onodera et al. 2007, 100).

The major impetus for Japan's Nature Restoration Act can be traced to the national government's engagement with international agreements like the Convention on Biological Diversity and the Ramsar Convention in the 1990s. As Telesetsky et al. (2017) remark, the idea of nature restoration has been a keen interest of many countries, becoming a regular theme "at nearly every [Convention on Biological Diversity] conference” (130). In 1996, for example, all parties under the Convention on Biological Diversity, including Japan, agreed to "take action[s] to achieve the restoration of habitats including their biological diversity component" (Telesetsky et al. 2017, 130). At the same time, ecological restoration was being pursued under the Ramsar framework. Although the original 1971 text of Ramsar made no mention of restoration, the COP in 1990 urged all members to undertake wetland restoration (Telesetsky et al. 2017, 96). Three years later, at the Kushiro COP in 1993, member states including Japan agreed to intensify their focus on wetland restoration with a view to delivering benefits for both humans and biodiversity (Telesetsky et al. 2017, 96). Accordingly, Japan's Nature Restoration Act is not an isolated initiative. It reflects a longer engagement with the international community through both the Convention on Biological Diversity and the Ramsar Convention surrounding the concept of restoration.

\section{What does the Nature Restoration Act do?}

Responding to international best practice, as exemplified by the Convention on Biological Diversity and the Ramsar Convention, the Nature Restoration Act essentially provides a framework to allow for and encourage the practices of ecological restoration in Japan. Article 3 of the law sets out the basic 'principles' by which restoration is to occur, summarised as follows: (1) restoration should occur in cooperation with a range of government and non-government stakeholders; (2) restoration should be based upon sound scientific knowledge; and (3) restoration should be aligned with community participation and educational activities. These principles are further reflected in MOEJ's Basic Policy for Nature Restoration (自然再生の ための基本方針), which also highlights the need for an 'adaptive management' approach (MOEJ n.d.[c]).

The link between Japan's Nature Restoration Act and international law is evident in these principles. The reference to scientific knowledge (principle 2 above), for example, broadly reflects the goals of the 'precautionary principle,' a concept which maintains that decisions should be based upon, and

(n)


justified by, the best available science (de Sadeleer 2010). More specifically, the principle is meant to ensure that, in the absence of scientific knowledge, actions to protect the environment should not be postponed. In other words, where threats to the environment are unknown, decision-makers should err on the side of caution. Similarly, the principle of 'public participation', also a principle under international environmental law (Sands and Peel 2018), is clearly reflected in the Nature Restoration Act through principle (3) above. The desire for the public to be involved is also articulated in the MOEJ's Basic Policy on Restoration which accompanies the law:

In the implementation of a nature restoration project, it is important to have the participation and cooperation of various actors in the region, including the concerned governmental agencies, concerned local governments, local residents, specified non-profit corporations and other civil organisations... and individuals with specialised knowledge of the natural environment, from the initial stage of formulating the concept of the nature restoration project, designing surveys, and implementing the project, to maintenance after the project has been implemented.

(MOEJ n.d.[c])

Seen against the background of earlier discussions, these examples show how Japan's environmental law dovetails with international governance frameworks while also achieving cohesion with domestic legislation (through its restoration ethos) and fostering grassroots participation and engagement (by localising the nomination of Ramsar sites, among other measures). In doing so, Japan's environmental laws have laid the groundwork for crosssector collaboration on numerous significant nature restoration projects that have been spearheaded by local governments (often in conjunction with NGOs), are endorsed and funded by the national government, and are increasingly integrated with global environmental agreements. The sections below discuss how these collaborations manifest in practice and examine the provisions for them within the law.

\section{How are Nature Restoration Projects Implemented in Japan?}

After establishing the basic principles above, derived as they have been from international environmental law, the Nature Restoration Act goes on to outline the responsibilities of both national and local governments in Japan, requiring them to act as facilitators or supporters of restoration projects (Article 4). Thereafter, article 5 turns our attention to the "effectors" (or 'implementers') of nature restoration projects which include NGOs, private corporations and other non-state actors. The law states that a committee system is to be established for each restoration project which includes both governmental and non-government stakeholders (Article 8), and that special consideration is given for how permits and other "legally prescribed" activities should occur to ensure "smooth and speedy" implementation of projects (Article 12). Each project requires an "implementation plan" which is subject to the approval of the MOEJ, the Ministry of Agriculture, Forestry and Fisheries (MAFF) and the Ministry of Land, Infrastructure, Transport and Tourism (MLIT). The resulting process is outlined in Figure 2 (below).

(n)




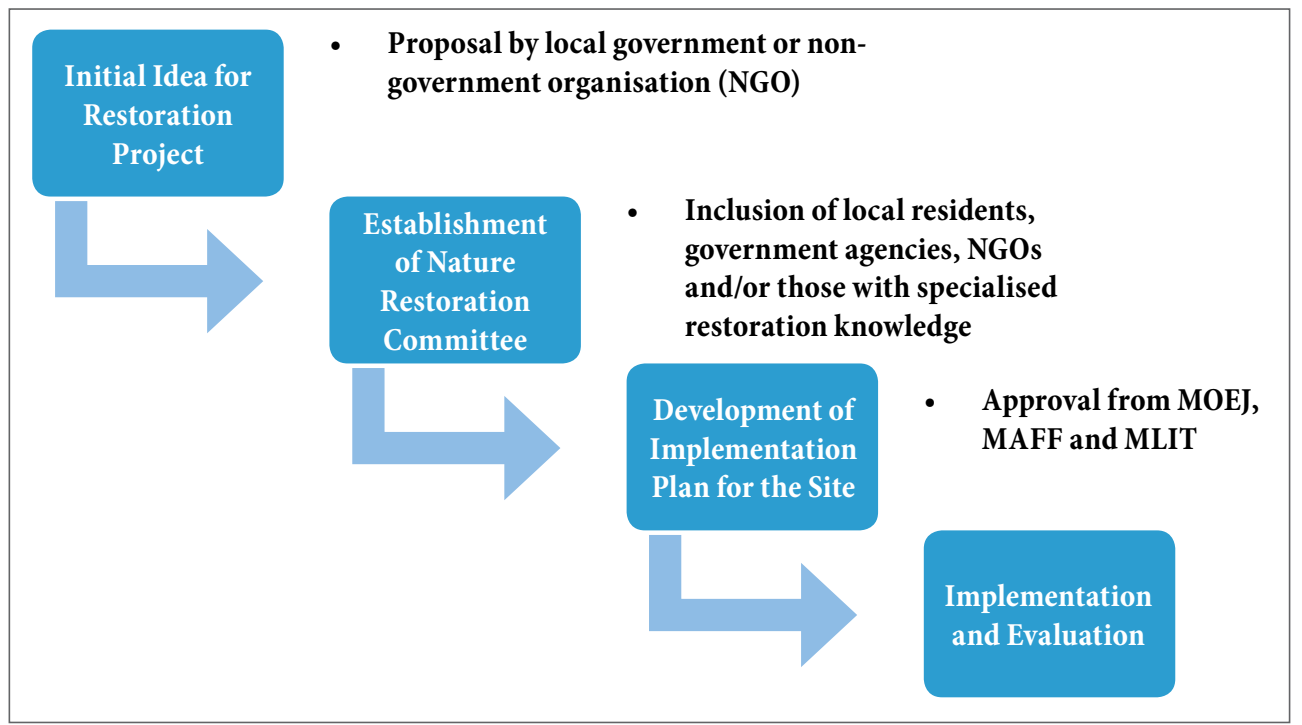

Figure 2: An illustration of the staged process from conceptualisation of a restoration project under the Nature Restoration Act through to implementation and evaluation

\section{What Kinds of Projects have been Implemented under the Law?}

Approximately half of the restoration projects that have been established since the Nature Restoration Act was passed in 2002 relate to wetlands in some way (the others concern grasslands, coral reefs and forested areas). Examples of major wetland restoration projects initiated under the law, including the causes of degradation and restorative measures, are set out in Appendix 3. Most of the wetland projects have been driven by municipal governments, with only two (Kushiro and Sarobetsu) driven at the national level (MOEJ 2009). This indicates the extent to which grassroots involvement is crucial to nature restoration in Japan. The national government has formulated policy to support nature restoration, but rarely spearheads restoration projects. Therefore, in practical terms, it can be argued that community awareness, engagement and action are equally important to the wellbeing of Japan's natural environment as its national-level policy architecture.

\section{TOWARDS EFFECTIVE WETLAND RESTORATION: WHERE TO FROM HERE?}

\section{Meaningful Participation of Local Communities}

Under the Nature Restoration Act, the Japanese government makes provisions for 'the state' (including prefectural and local governments in Japan) to play a cooperative role in restoration. The main collaborators in restoration projects are intended to be NGOs, scientists, universities and the Japanese private sector. A stated distinction in the law between 'governments' and 'effectors' makes the desire for collaboration clear. By a similar token, specific reference is made in the law to Article 2 of the 1998 Act to Promote Specified NonProfit Activities in Japan (特定非営利活動促進法), ostensibly with the aim of harnessing and leveraging the "specialized [restoration] knowledge" of those in the NGO and private sector.

(n)


All of this reflects an explicit attempt to establish a collaborative governance approach to nature restoration in Japan. The phrase 'collaborative governance' is well covered in the broader governance literature and in environmental matters is often considered best practice in achieving conservation goals (Gunningham 2009; Bodin 2017). Collaborative governance is a broad concept and may be defined as follows:

A governing arrangement where one or more public agencies directly engage non-state stakeholders in a collective decision-making process that is formal, consensus-oriented, and deliberative and that aims to make or implement public policy or manage public programs or assets.

(Ansell and Gash 2008, 544)

Ansell and Gash's (2008) definition describes three elements of a collaborative framework: (1) an initiative driven first and foremost by a public agency (e.g., the MOEJ); (2) an initiative which is formal but also consensus-driven (e.g., established through rules, laws or written processes); and (3) an initiative which aims to implement a public program or policy (e.g., wetlands restoration). At face value, Japan's Nature Restoration Act satisfies each of these three elements, providing a further example of its dovetailing with internationally recognised best practice.

However, the effective implementation of collaborative restoration is another question. Rushed efforts to revive natural environments without appropriate expertise, public inclusion or robust assessment of long-term impacts can result in poor socio-ecological outcomes, and there are lessons to be learnt from examples akin to this in Japan. In the case of restoration efforts in the tsunami zone following the Great East Japan Earthquake, for instance, 40foot seawalls were built in Iwate prefecture. The walls were intended to stop any future tidal surges or tsunamis, but many locals have claimed feeling like they are "in jail" (Jacobs 2018). In this way, 'restorative measures' which were ostensibly pursued in the public interest have carved a rift between local communities and the natural seascapes upon which their pre-disaster livelihoods may have depended.

In another example of restoration efforts with unintended consequences, the mass replanting of the Japanese countryside with cedar (Cryptomeria japonica; 杉) forests in the 1950s, 1960s and 1970s in response to deforestation resulted in an "annual allergy epidemic" in Japan due to increased pollen in the air (Singleton 2015). These cedar-dominated landscapes have also depleted the original richness of the natural forests, causing Japanese Black Bears (Ursus thibetanus japonicus; ツキノワクマ) to venture closer to the villages in search of food and thereby causing conflict with humans (Knight 2007). In 2006, over 4,500 bears were culled in the name of human protection (Knight 2007, 5), and across Japan, the phenomenon is now referred to as "kuma mondai," or "the bear problem" (6).

As these examples illustrate, human interventions into ecosystems in the name of restoration can result in perverse socio-ecological outcomes, such as biodiversity loss and/or the isolation of local communities that 
rely on wetlands for their livelihoods. Interventions into ecosystems (as socio-ecological landscapes) that are designed and implemented in close consultation with those who live or rely on them and are backed by the best available science are arguably likely to reduce these problems. The challenge, therefore, is to design and implement effective models of collaborative governance. As Bodin (2017) writes:

addressing the issue [of collaboration] is clearly not as simple as just establishing collaboration among a large set of actors and stakeholders, and then all will be well. Rather, the questions are when and how collaboration is effective, for what kind of environmental problems is it useful, and if and how this relates to the temporal and spatial characteristics of the governed ecosystems.

(1)

To achieve this may require a deeper level of thinking around how, where and why people live within certain wetland landscapes in Japan. It is to those considerations we now briefly turn.

\section{Integrating Wetland Restoration within Existing Socio-Ecological Landscapes}

The concepts of satoyama and satoumi have been and continue to be integral to wetland and coastal management in Japan. In Japanese, 'sato' (里) means 'village', 'yama' (山) means 'mountain' and 'umi' (海) means 'sea'. Thus, 'satoyama' refers to the area of land between the mountain and the village (i.e., the landscape), whilst 'satoumi' refers to the area between the village and the sea (i.e., the seascape). Both satoyama and satoumi are classified as "socioecological production landscapes" under international law (Secretariat of the Convention on Biological Diversity 2011, 73) and have been formally recognised as positive drivers of sustainability in the Japanese Government's National Biodiversity Strategy.

Sadly, both satoumi and satoyama have been declining in recent years due to increased urbanisation, infrastructure development and the loss of connection between people, their traditional farming methods and the natural world (Duraiappah et al. 2012). In some cases, entire villages have withdrawn from rice paddy cultivation, leaving them to dry out, which has had flow-on effects for wetlands. For example, in the area of Eastern Kosado (小佐渡東 部) in Niigata prefecture, the abandonment of traditional rice terraces due to aging farmers and mechanised production has seen declines in local birdlife which has come to rely on the area (MOEJ 2009, 29). Takeuchi et al. (2015) summarise the satoyama problems Japan is facing as follows:

...abandonment of farmland and neglect of forests and agricultural facilities are ongoing due to depopulation (particularly aging and desertion in rural areas), changes in industrial structures, and dependency on external agricultural products and energy, leading to underuse of domestic natural resources, which is affecting the natural environment and biodiversity. 
In recent times, the national government has introduced efforts to reinvigorate landscapes like satoumi and satoyama. Japan was instrumental, for instance, in launching the International Partnership for the Satoyama Initiative (SATOYAMA イニシアティブ国際パートナーシップ) in 2010 (MOEJ 2012,17 ), which is now comprised of 253 member organisations striving to realise a global society 'in harmony with nature' (IPSI 2019). However, while satoyama has been recognised within Japan's Nature Restoration Act (Article 2), no major projects to date-with the possible exception of the restoration of the Eastern Kosado wetlands (see Appendix 3) - have specifically aimed to revitalise satoyama landscapes (MOEJ 2009).

This suggests that more needs to be done to extend legal frameworks for nature restoration to include degraded or under-utilised wetland landscapes. There are ample opportunities to drive this under the Ramsar Convention's 'Wise Use' concept, and indeed, there are numerous examples of Japan encouraging the sustainable use of resources by people in its wetlands (Tsujii and Sasagawa 2012). However, at present, there appear to have been no meaningful attempts to establish wetland restoration projects that revitalise satoyama or satoumi landscapes under the law. This likely requires a more sophisticated administrative approach by the government, or, as Takeuchi et al. (2015) write, "[it requires] policies [that] deal with issues in interconnected and coupled systems" (38). However, a look at Japan's existing environmental law suggests that new policies need not be formulated. There are ample opportunities within the current legal framework to revitalise satoyama and satoumi environments; what is needed is an administrative vision which more deeply connects Japan's wetlands to their "functional relationships among different [landscape] production activities ... [such as] forestry, agriculture and fisheries." (Takeuchi et al. 2015, 35). In short, landscape-scale approaches to wetland restoration are required.

\section{CONCLUSION}

Japan's spectacular economic growth in the post-war era resulted in severe degradation of its wetland environments. As a consequence, biodiversity has experienced declines. Japan's wetlands need to be restored and enhanced in order to replenish and enliven their value to wildlife and society. I argue that this can be achieved through increased cross-sector and community collaboration which is centred on an awareness of traditional landscape uses and harnesses traditional cultural practices. The government of Japan has recognised the extent of wetland degradation and sought to establish a 'harmony' between people and nature through the law.

The passage of the Nature Restoration Act in 2002 was a landmark moment for Japan. At its heart, this law is about collaborative governance; that is, the partnering of NGOs, governments and private institutions to carry out restoration work. Over two dozen major projects have already been initiated under the Nature Restoration Act, including several major works relating to wetlands. Ultimately, Japan is a nation well-placed to restore its wetlands 
because of its history of recovery in other areas and its sophisticated legal framework which lays the foundations for such measures to occur. However, to realise the Act's goals, greater efforts are needed to focus attention at the landscape scale and further involve local communities in restorative works.

\section{GLOSSARY}

\section{COP}

'Conference of the [Ramsar] Contracting Parties'; the name given to the triennial meetings related to the Ramsar Convention, where the listing of wetland sites is resolved and mechanisms for conservation and restoration are discussed. COPs are attended by delegates of nations that are signatories to Ramsar, as well as relevant NGOs.

\section{EAAF}

East Asian-Australasian Flyway; one of nine major routes travelled annually by migratory birds, stretching from New Zealand and Australia in the south to Russia and the United States (Alaska) in the north.

\section{EAAF Partnership}

A non-binding arrangement to conserve migratory waterbirds sites throughout the EAAF, with 18 member nations as at June 2019

\section{Fuyumizu-tambo (冬水田んぼ)}

Also, fuyumizu-tanbo. Lit., 'winter water rice field'; the agricultural practice of submerging ricefields throughout the winter off-season, which allows rice to be cultivated without the use of chemical pesticides or fertilisers.

\section{Higata (干潟)}

Tidal mud flats

\section{IPSI}

International Partnership for the Satoyama Initiative; a global project with 253 member states, led by Japan, with the aim of reinvigorating satoumi- and satoyamatype landscapes.

\section{MAFF}

Ministry of Agriculture, Forestry and Fisheries, Japan

\section{MILT}

Ministry of Land, Infrastructure, Transport and Tourism, Japan

\section{MOEJ}

Ministry of the Environment, Japan

\section{Ramsar Convention}

The main international treaty governing wetland conservation, established in 1971

\section{Satoumi (里海)}

The area between a village and the sea (i.e., the seascape). Satoumi areas, like their satoyama counterparts, are classified as 'socio-ecological production landscapes' under international law. The satoumi and satoyama concepts have been and continue to be integral to wetland management in Japan. 
The area between a village and the mountains (i.e., the landscape). For further

information, see satoumi (above).

Wanokuni Zukuri (『環の国』づくり)

The name of a sustainability initiative proposed by the Japanese government in 2001, which can be variously translated as 'developing our nation,' 'developing an environmental [eco-friendly] nation' and 'developing a harmonious nation.'

\section{Appendix 1. Japanese and International Environmental Governance Frameworks Cited}

\section{Japanese}

Act for the Promotion of Nature Restoration, 2002 (Nature Restoration Act)

自然再生推進法

National Biodiversity Strategy 2012-2020 (incorporates the national wetland policy) 日本の生物多様性国家戦略

River Act, 1997 amendment

河川法

Basic Act on Reconstruction in Response to the Great East Japan Earthquake, 2011 (Tohoku Reconstruction Act)

東日本大震災に対する復興基本法

Special Measures for the Reconstruction and Revitalisation of Fukushima 福島の復興と活性化のための特別措置

Basic Policy for Nature Restoration

自然再生のための基本方針

Act to Promote Specified Non-Profit Activities in Japan, 1998 (Article 2)

特定非営利活動促進法

Wanokuni Zukuri, 2001

『環の国』づくり

\section{International}

Convention on Biological Diversity

生物多様性に関する条約

Convention on Migratory Species

移動性野生動物種の保全に関する条約

East Asian-Australasian Flyway Partnership (EAAF Partnership)

東アジア・オーストラリア地域フライウェイパートナーシップ (EAAFパートナーシップ)

International Partnership for the Satoyama Initiative

SATOYAMA イニシアティブ国際パートナーシップ 


\section{Appendix 2. Examples of Rice Fields as Bird Habitat in Lake Biwa}
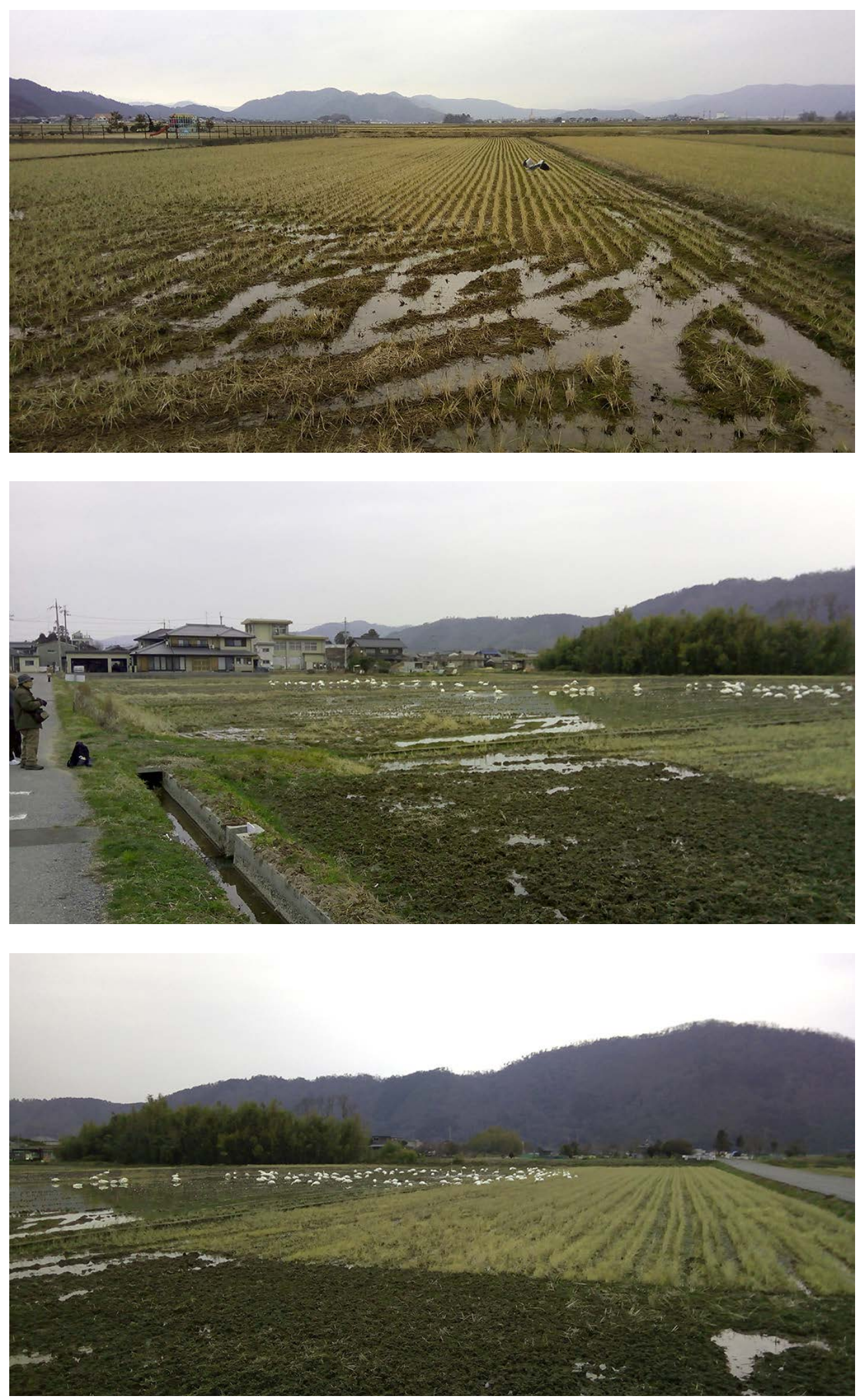

Figure 1 (top), Figure 2 (centre) and Figure 3 (bottom): Rice fields provide important habitat for birdlife in the wetlands adjacent to Lake Biwa. 


\section{Appendix 3. Examples of Major Wetland Restoration Projects in Japan Undertaken in Accordance with the Nature Restoration Act}

\begin{tabular}{|c|c|c|c|c|c|}
\hline $\begin{array}{l}\text { Name of Wetland } \\
\text { (and Location) }\end{array}$ & $\begin{array}{l}\text { Sponsoring } \\
\text { Authority }\end{array}$ & $\begin{array}{l}\text { Ramsar } \\
\text { Status }\end{array}$ & $\begin{array}{l}\text { EAAFP } \\
\text { Status }\end{array}$ & Causes of Degradation & Restorative Measures \\
\hline $\begin{array}{l}\text { Kushiro Wetland } \\
\text { (Kushiro, Hokkaido) }\end{array}$ & MOEJ & $\begin{array}{l}\text { Listed } \\
\text { (1980) }\end{array}$ & $\begin{array}{l}\text { Listed } \\
\text { (1997) }\end{array}$ & $\begin{array}{l}\text { - Encroachment and irrigation } \\
\text { of agricultural lands } \\
\text { neighbouring the site } \\
\text { - Diversion of the Kushiro } \\
\text { River for irrigation and } \\
\text { flood control }\end{array}$ & $\begin{array}{l}\text { - Erosion control } \\
\text { - Raising of the groundwater } \\
\text { table } \\
\text { - Replanting of wetland } \\
\text { vegetation } \\
\text { - Restoring the Kushiro River to } \\
\text { natural (meandering) flow }\end{array}$ \\
\hline $\begin{array}{l}\text { Sarobetsu } \\
\text { (Teshio-gun, } \\
\text { Hokkaido) }\end{array}$ & MOEJ & $\begin{array}{l}\text { Listed } \\
\text { (2005) }\end{array}$ & Not Listed & $\begin{array}{l}\text { - Decades of peat mining } \\
\text { lover } 150 \text { ha of wetlands } \\
\text { lost) }\end{array}$ & $\begin{array}{l}\text { - Rehabilitation of wetland } \\
\text { vegetation in abandoned } \\
\text { peat mining areas } \\
\text { - Establishment of buffer zones } \\
\text { and retention ponds }\end{array}$ \\
\hline $\begin{array}{l}\text { Gamo Tidal Flat } \\
\text { (Sendai, Miyagi } \\
\text { prefecture) }\end{array}$ & $\begin{array}{l}\text { Municipal } \\
\text { Government }\end{array}$ & Not Listed & Not Listed & $\begin{array}{l}\text { - Impacted by construction of } \\
\text { Sendai Port and river } \\
\text { engineering work } \\
\text { - Sand incursions from the } \\
\text { ocean causing detriment } \\
\text { and poor water flow to/from } \\
\text { site }\end{array}$ & $\begin{array}{l}\text { - Sand transport control } \\
\text { - Channel dredging }\end{array}$ \\
\hline $\begin{array}{l}\text { Sanbanze } \\
\text { (Urayasu, Ichikawa, } \\
\text { Funabashi and } \\
\text { Narashino, Chiba } \\
\text { prefecture) }\end{array}$ & $\begin{array}{l}\text { Municipal } \\
\text { Government }\end{array}$ & Not Listed & Not Listed & $\begin{array}{l}\text { - Increased landfill, } \\
\text { subsidence and erosion } \\
\text { - Pollution from wastewater }\end{array}$ & $\begin{array}{l}\text { - Expansion of tidal flat area } \\
\text { - Tidal flushing } \\
\text { - Filling deep areas } \\
\text { - Enhancing freshwater flow }\end{array}$ \\
\hline $\begin{array}{l}\text { Lake Izunuma- } \\
\text { Uchinuma } \\
\text { (Tome and Kurihara, } \\
\text { Miyagi prefecture) }\end{array}$ & $\begin{array}{l}\text { Municipal } \\
\text { Government }\end{array}$ & $\begin{array}{l}\text { Listed } \\
\text { (1985) }\end{array}$ & $\begin{array}{l}\text { Listed } \\
\text { (2014) }\end{array}$ & $\begin{array}{l}\text { - Development of irrigation } \\
\text { and flood-water retention } \\
\text { ponds } \\
\text { - Several years of heavy } \\
\text { rainfall }\end{array}$ & $\begin{array}{l}\text { - Growing and transplanting } \\
\text { emergent and submersed plants } \\
\text { - Breeding and transferring } \\
\text { native fish and mussels }\end{array}$ \\
\hline $\begin{array}{l}\text { Eastern Kosado } \\
\text { (Sado, } \\
\text { Niigata prefecture) }\end{array}$ & $\begin{array}{l}\text { Municipal } \\
\text { Government }\end{array}$ & Not Listed & Not Listed & $\begin{array}{l}\text { - Abandonment of } \\
\text { surrounding rice paddies } \\
\text { - Lack of care for surrounding } \\
\text { forests }\end{array}$ & $\begin{array}{l}\text { - Planting of wetland vegetation } \\
\text { and improving water flows } \\
\text { - Reintroduction of water birds, } \\
\text { such as Japanese Crested Ibis }\end{array}$ \\
\hline $\begin{array}{l}\text { Lake Biwa } \\
\text { (Nagahama and } \\
\text { Kohoku, Shiga } \\
\text { prefecture) }\end{array}$ & $\begin{array}{l}\text { Municipal } \\
\text { Government }\end{array}$ & $\begin{array}{l}\text { Listed } \\
\text { (1993) }\end{array}$ & $\begin{array}{l}\text { Listed } \\
\text { (1999) }\end{array}$ & $\begin{array}{l}\text { - Land reclamation of lagoon } \\
\text { areas } \\
\text { - Declines in reed covers and } \\
\text { riparian forests through } \\
\text { urban use/encroachment }\end{array}$ & $\begin{array}{l}\text { - Flooding of reclaimed land } \\
\text { - Installation of walls and jetties } \\
\text { to stabilise sediment }\end{array}$ \\
\hline $\begin{array}{l}\text { Yawata Wetlands } \\
\text { (Kitahiroshima, } \\
\text { Yamagata-gun, } \\
\text { Hiroshima } \\
\text { prefecture) }\end{array}$ & $\begin{array}{l}\text { Municipal } \\
\text { Government }\end{array}$ & Not Listed & Not Listed & $\begin{array}{l}\text { - Drainage of wetlands, } \\
\text { primarily due to pastoral } \\
\text { agriculture }\end{array}$ & $\begin{array}{l}\text { - Rehabilitation of wetland } \\
\text { vegetation and control of } \\
\text { invasive species } \\
\text { - Removing the drainage canal, } \\
\text { installation of levees }\end{array}$ \\
\hline $\begin{array}{l}\text { Harima Irrigation } \\
\text { Ponds } \\
\text { (Ono, Kasai and } \\
\text { Kato, Hyogo } \\
\text { prefecture) }\end{array}$ & $\begin{array}{l}\text { Municipal } \\
\text { Government }\end{array}$ & Not Listed & Not Listed & $\begin{array}{l}\text { - Decrease in size of pond } \\
\text { areas } \\
\text { - Reduced water quality from } \\
\text { invasion of alien species }\end{array}$ & $\begin{array}{l}\text { - Removal of rodents } \\
\text { - Removing lotus and reducing } \\
\text { dense reed coverage }\end{array}$ \\
\hline $\begin{array}{l}\text { Fushino River Tidal } \\
\text { Flats } \\
\text { (Yamaguchi, } \\
\text { Yamaguchi } \\
\text { prefecture) }\end{array}$ & $\begin{array}{l}\text { Municipal } \\
\text { Government }\end{array}$ & Not Listed & Not Listed & $\begin{array}{l}\text { - Eutrophication from } \\
\text { upstream agricultural and } \\
\text { urban uses } \\
\text { - Oyster overpopulation due } \\
\text { to enrichment of estuarine } \\
\text { water } \\
\text { - Compaction of mud flat and } \\
\text { decline of eelgrass }\end{array}$ & $\begin{array}{l}\text { - Shell crushing and ploughing in } \\
\text { high-density areas of oyster } \\
\text { shells } \\
\text { - Ploughing in the sandy areas }\end{array}$ \\
\hline $\begin{array}{l}\text { Kashibaru Wetlands } \\
\text { (Karatsu, Saga } \\
\text { prefecture) }\end{array}$ & $\begin{array}{l}\text { Municipal } \\
\text { Government }\end{array}$ & Not Listed & Not Listed & $\begin{array}{l}\text { - Road construction } \\
\text { - Agricultural practices } \\
\text { lincluding cessation of field } \\
\text { burningl }\end{array}$ & $\begin{array}{l}\text { - Increasing open water supply } \\
\text { - Dredging } \\
\text { - Removal of dead vegetation }\end{array}$ \\
\hline
\end{tabular}

Source: MOEJ (2009). Note: All sites in this table are included in the MOEJ's list of Japan's 


\section{REFERENCES}

Akhtar-Khavari, A. and B. Richardson. 2019. Ecological Restoration Law Concepts and Case Studies. Oxford: Routledge.

Akhtar-Khavari, A. and A. Telesetsky. 2016. "From Protection to Restoration: A Challenge for Environmental Governance." In Research Handbook on Fundamental Concepts of Environmental Law, edited by D. Fisher, 50-81. Cheltenham: Edward Elgar Publishing. https://doi.org/10.4337/9781784714 659.00009 .

Amano, T., T. Szekely, K. Koyama, H. Amano and W. J. A. Sutherland. 2010. "A Framework for Monitoring the Status of Populations: An Example from Wader Populations in the East Asian-Australasian Flyway." Biological Conservation 143 (9): 2238-47. https://doi.org/10.1016/j.biocon.2010.06.010.

Ansell, C. and A. Gash. 2008. "Collaborative Governance in Theory and Practice." Journal of Public Administration Research and Theory 18 (4): 543-71. https:// doi.org/10.1093/jopart/mum032.

Aronson, J., et al. 2011. "What Role Should Government Regulation Play in Ecological Restoration? Ongoing Debate in Sao Paulo State, Brazil." Restoration Ecology 19 (6): 690-95. https://doi.org/10.1111/j.1526-100X. 2011.00815.x.

Asano, T. 2014. "International Nature Reserves and Local Inhabitants: The Case of the 'Wise Use' of Ramsar Wetlands in Japan." Japanese Journal of Human Geography 66 (6): 48-63. https://doi.org/10.4200/jjhg.66.6_536.

Barresi, P. 2017. “The Role of Law and the Rule of Law in China's Quest to Build an Ecological Civilisation." Chinese Journal of Environmental Law 1 (1): 9-36. https://doi.org/10.1163/24686042-12340003.

Birdlife International. 2017. "Numenius madagascariensis (amended version of 2016 assessment)." The IUCN Red List of Threatened Species 2017: e.T22693199 A118601473. Accessed 13 June, 2019. https://doi.org/10.2305/IUCN.UK. 2017-3.RLTS.T22693199A118601473.en.

Bodin, Ö. 2017. "Collaborative Environmental Governance: Achieving Collective Action in Social-Ecological Systems." Science 357 (6352): eaan1114. https:// doi.org/10.1126/science.aan1114.

Cho, A. 2014. "Post-Tsunami Recovery and Reconstruction: Governance Issues and Implications of the Great East Japan Earthquake.” Disasters 38 (s2): s15778. https://doi.org/10.1111/disa.12068.

Davidson, N. 2014. "How Much Wetland has the World Lost? Long-Term and Recent Trends in Global Wetland Area." Marine and Freshwater Research 65 (10): 934-41. https://doi.org/10.1071/MF14173.

de Sadeleer, N. 2010. "The Precautionary Principle in EU Law." Aansprakelijkheid Verzekering En Schade 5: 173-84. 
Dempster, P. 1967. Japan Advances: A Geographical Study. London: Methuen.

Duraiappah, A. K., K. Nakamura and K. Takeuchi. 2012. Satoyama-Satoumi Ecosystems And Human Well-Being: Socio-Ecological Production Landscapes Of Japan. Tokyo: United Nations University Press.

EAAF Partnership. n.d. 'Migratory Waterbirds, Far Eastern Curlew," EAAFP. Accessed 19 October, 2018. https://eaaflyway.net/migratory-waterbirds/fareastern-curlew/.

Endoh, T. 2004. "Historical Review of Reclamation Works in the Tokyo Bay Area." Journal of Geography (Chigaku Zasshi) 113 (6): 785-801. https://doi.org/ 10.5026/jgeography.113.6_785.

Eyre, J. 1956. "Japanese Land Development in Kojima Bay." Economic Geography 32 (1): 58-74. https://doi.org/10.2307/141931.

Fletcher, S., M. Kawabe and S. Rewhorn. 2011. "Wetland Conservation and Sustainable Coastal Governance in Japan and England." Marine Pollution Bulletin 62 (5): 956-62. https://doi.org/10.1016/j.marpolbul.2011.02.048.

Fujioka, M., S. Lee, M. Kurechi and H. Yoshida. 2010. "Bird Use of Rice Fields in Korea and Japan.” Waterbirds 33 (1): 8-29. https://doi.org/10.1675/063.033. s102.

Fujita, H., Y. Igarashi, S. Hotes, M. Takada, T. Inoue, and M. Kaneko. 2009. “An Inventory of the Mires of Hokkaido, Japan: Their Development, Classification, Decline, and Conservation." Plant Ecology 200 (1): 9-36. https://doi.org/10.1007/s11258-007-9267-z.

Gunningham, N. 2009. "The New Collaborative Environmental Governance: The Localization of Regulation." Journal of Law and Society 36 (1): 145-66. https://doi.org/10.1111/j.1467-6478.2009.00461.x.

Haidary, A., B. J. Amiri, J. Adamowski, N. Fohrer and K. Nakane. 2013. "Assessing the Impacts of Four Land Use Types on the Water Quality of Wetlands in Japan." Water Resources Management 27 (7): 2217-29. https://doi. org/10.1007/s11269-013-0284-5.

Hamman, E. 2018. "Cultural Perceptions and Natural Protections: A Socio-Legal Analysis of Public Participation, Birdlife and Ramsar Wetlands in Japan." Asia Pacific Journal of Environmental Law 21: 4-28. https://doi.org/10.4337/ apjel.2018.01.01.

Hong, J. K. and Iisaka, J. 1982. "Coastal Environment Change Analysis by Landsat MSS Data” Remote Sensing of Environment 12 (2): 107-16. https:// doi.org/10.1016/0034-4257(82)90030-X.

Ichikawa, H. 1994. “The Evolutionary Process of Urban Form in Edo/Tokyo to 1900." The Town Planning Review 65 (2): 179-96. https://doi.org/10.3828/ tpr.65.2.j81596x50p367031. 
Ichikawa, T., M. Yasuda, T. Nuka, T. Moriya, M. Kashiwagi, K. Chen and T. Shibahara. 2017. "Population Decline of Migratory Waterbirds and Habitat ChangesShorebirds as Indicators." In Proceedings of the 8th Asian Wetland Symposium, Saga, Japan, 7-11 November. http://aws2017.org/documents/ proceedings.pdf.

IPSI (International Partnership for the Satoyama Initiative). 2019. "Concept," International Partnership for the Satoyama Initiative. Accessed 1 March, 2019. https://satoyama-initiative.org/about/.

Jacobs, S. 2018. “It Feels Like We're in Jail': Japan Spent $\$ 12$ Billion on Seawalls After the Devastating 2011 Tsunami-and now Locals are Feeling like Prisoners." Business Insider, 12 March. Accessed 1 March, 2019. https://www.businessinsider.com/japan-seawalls-cost-12-billion-sincefukushima-disaster-2018-3/.

Japan Times, The. 2001. "500 Important Wetlands Named in National Biodiversity Plan.” The Japan Times, 12 October. Accessed 20 June, 2019. https://www. japantimes.co.jp/news/2001/10/12/national/500-important-wetlandsnamed-in-biodiversity-plan/.

Knight, C. 2007. The Bear as a Barometer: The Japanese Response to Human-Bear Conflict.Doctoral thesis, The University of Canterbury. https://ir.canterbury. ac.nz/bitstream/handle/10092/991/thesis_fulltext.pdf?sequence $=1$ \&isAllowed $=\mathrm{y}$.

Koh, C. H. and V. de Jonge. 2014. "Stopping the Disastrous Embankments of Coastal Wetlands by Implementing Effective Management Principles: Yellow Sea and Korea Compared to the European Wadden Sea." Ocean \& Coastal Management 102: 604-21. https://doi.org/10.1016/j.ocecoaman. 2014.11.001.

McCormack, G. 1996. The Emptiness of Japanese Affluence. London: Routledge.

Mittermeier, R. A., C. G. Mittermeier and P. Robes Gil. 1997. Megadiversity: Earth's Biologically Wealthiest Nations. 1st English edition. Mexico City: CEMEX.

Mo, W., M. Lee, M. Uchida, M. Inatomi, N. Saigusa, S. Mariko and H. Koizumi. 2005. "Seasonal and Annual Variations in Soil Respiration in a CoolTemperate Deciduous Broad-Leaved Forest in Japan." Agricultural and Forest Meteorology 134 (1-4): 81-94. https://doi.org/10.1016/j.agrformet. 2005.08.015.

MOEJ (Ministry of the Environment, Japan). n.d.[a]. Ramsar Sites in Japan, p. 2. Accessed 19 October, 2018. https://www.env.go.jp/en/nature/npr/ramsar_ wetland/pamph/ramsarpamphen/RamsarSites_en_web02.pdf.

MOEJ (Ministry of the Environment, Japan). n.d.[b]. Ramsar Sites in Japan, p. 3. Accessed 19 October, 2018. https://www.env.go.jp/en/nature/npr/ramsar_ wetland/pamph/ramsarpamphen/RamsarSites_en_web03.pdf.

MOEJ (Ministry of the Environment, Japan). n.d.[c]. Basic Policy for Nature Restoration. Accessed 19 October, 2018. https://www.env.go.jp/en/nature/ npr/bpnr.pdf. 
MOEJ (Ministry of the Environment, Japan). 2001. "Jūyō shicchi no sentei (torimatome kekka) ni tsuite (重要湿地の選定 (とりまとめ結果)について).” Media release. Ministry of the Environment, 27 December. Accessed 20 June, 2019. http:// www.env.go.jp/press/press.php?serial=3068.

MOEJ (Ministry of the Environment, Japan). 2009. Nature Restoration Projects in Japan: Towards Living in Harmony with the Natural Environment. Accessed 3 March, 2019. https://www.env.go.jp/en/nature/npr/nrp_japan/ pdf/full.pdf.

MOEJ (Ministry of the Environment, Japan). 2012. The National Biodiversity Strategy of Japan 2012-2020: Roadmap towards the Establishment of an Enriching Society in Harmony with Nature. 28 September. Accessed 19 October, 2018. https://www.env.go.jp/press/files/en/528.pdf.

Murray, N., R. Clemens, S. Phinn, H. Possingham and R. Fuller. 2014. "Tracking the Rapid Loss of Tidal Wetlands in the Yellow Sea." Frontiers in Ecology and the Environment 12 (5): 267-72. https://doi.org/10.1890/130260.

Nakamura, K., K. Tockner and K. Amano. 2006. "River and Wetland Restoration: Lessons from Japan.” BioScience 56 (5): 419-29. https://doi.org/10.1641/ 0006-3568(2006)056[0419:RAWRLF]2.0.CO;2.

Onodera, H., T. Watanabe and R. Kamezawa. 2007. "Idea of Nature Restoration." Global Environmental Research 11: 95-111.

Ramsar Convention Secretariat. 2014. "Ramsar Implementation in Japan." Ramsar, May 14. Accessed 19 October, 2018. https://www.ramsar.org/news/ramsarimplementation-in-japan.

Ramsar Network Japan. 2015. Increasing Japan's Ramsar Sites from 50 to 100. Accessed 20 June, 2019. http://www.ramnet-j.org/ramsar_cop12/wetland50100flyer.pdf.

Ramsar Sites Information Service. 2015. Ramsar Information Sheet: Japan, Higashiyoka-higata. 12 November. Accessed 19 October, 2018. https://rsis. ramsar.org/RISapp/files/RISrep/JP2234RIS_1505_en.pdf.

Sands, P. and J. Peel. 2018. Principles of International Environmental Law. Cambridge: Cambridge University Press.

Secretariat of the Convention on Biological Diversity. 2011. Contribution of Ecosystem Restoration to the Objectives of the CBD and a Healthy Planet for All People. Accessed 19 October, 2018. https://www.cbd.int/doc/publications/cbd-ts62-en.pdf.

SER (Society for Ecological Restoration). 2004. SER International Primer on Ecological Restoration. Accessed 31 May, 2019. https://c.ymcdn.com/sites/ www.ser.org/resource/resmgr/custompages/publications/SER_Primer/ser_ primer.pdf.

Shimba, T. 2007. A Photographic Guide to the Birds of Japan and North-East Asia. Yale University Press: New Haven and London. 
Singleton, J. 2015. “The Sneeze Trees: Ridding Japanese Forests of Pollen.” Nippon. com, 4 April. Accessed 3 March, 2019. https://www.nippon.com/en/ nipponblog/m00081/the-sneeze-trees-ridding-japanese-forests-of-pollen. html.

Takahashi, M. 2009. "Overview of the Structure and the Challenges of Japanese Wildlife Law and Policy." Biological Conservation 142 (9): 1958-64. https:// doi.org/10.1016/j.biocon.2009.05.009.

Takeuchi, K., K. Ichikawa and T. Elmqvist. 2015. "Satoyama Landscape as SocialEcological System: Historical Changes and Future Perspective." Current Opinion in Environmental Sustainability 19: 30-39. https://doi.org/10.1016/j. cosust.2015.11.001.

Telesetsky, A., A. Cliquet and A. Akhtar-Khavari. 2017. Ecological Restoration in International Environmental Law. London: Routledge. https://doi.org/ $10.4324 / 9781315757605$.

Totman, C. 1989. The Green Archipelago: Forestry in Preindustrial Japan. Los Angeles: University of California Press.

Totman, C. 2014. A History of Japan. New Jersey: Blackwell Publishing.

Tsujii T. and K. Sasagawa, eds. 2012. Thirty-three Examples of the Cultures and Technologies of Wetlands in Japan: Relationships with Local People and Communities. Tokyo: Wetlands International Japan. Accessed 19 October, 2018. http://archive.ramsar.org/pdf/33-Cultures-Technologies-booklet_ Japan.pdf.

Wada, T, T. Mitsushio, S. Inoue, H. Koike and R. Kawabe. 2016. "Movement Patterns and Residency of the Critically Endangered Horseshoe Crab (Tachypleus tridentatus) in a Semi-Enclosed Bay Determined Using Acoustic Telemetry." PLOS ONE 11 (2). https://doi.org/10.1371/journal.pone.0147429.

Watabe, Y. and S. Sassa. 2016. "History of Land Reclamation Using Dredged Soils at Tokyo Haneda Airport." Japanese Geotechnical Society Special Publication 2 (51): 1784-89. https://doi.org/10.3208/jgssp.TC217-04.

Zöckler, C., S. Delany and W. Hagemeijer. 2003. "Wader Populations are DecliningHow will we Elucidate the Reasons?” Wader Study Group Bull 100: 202-11. 


\section{A Sense of Communal Belonging in Digital Space: The Case of the 3.11 Disaster}

\section{SONJA PETROVIC}

The University of Melbourne

\section{ABSTRACT}

This article examines the role of social media in disaster communication and its potential to foster a sense of communal belonging through shared emotional connection, using the case study of the 3.11 disaster in Japan. The 2011 triple disaster had profound implications for new interactions among individuals, as the earthquake not only brought destruction to the surrounding environment, but also reconfigured many people's sense of place, security and communal belonging. I argue that, in a post-disaster context, social media had substantial implications for individuals' perceptions of belonging to local and regional communities, as it introduced new dimensions and forms of interaction among individuals, regardless of temporal and spatial barriers. Qualitatively approached, this study examines the evolving potential of social media to serve as a space where individuals can experience and express closeness in time of crisis, creating and maintaining new forms of affective communities in digital space. Based on in-depth interviews and social media data from Japan that relates to the 3.11 disaster, this article sheds light on how social media can enable users to experience a sense of belonging to local, regional and global communities through multi-level interaction with similar others.

\section{KEYWORDS}

3.11; affective communities; communal belonging; contemporary; digital space; disaster; multi-level interaction; social media
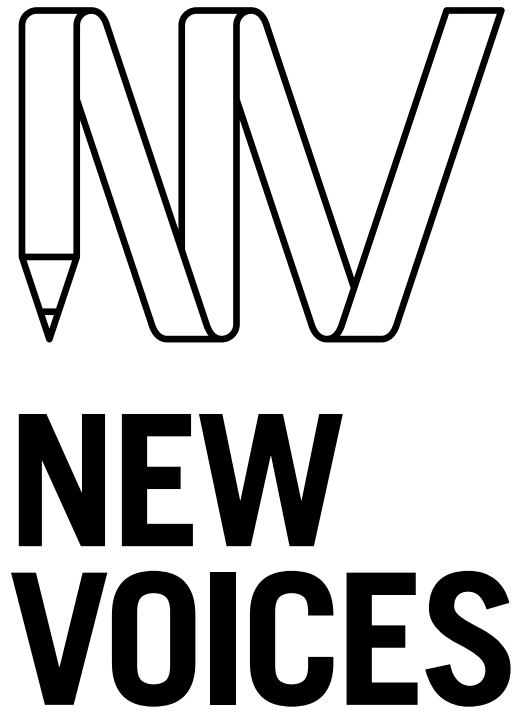

IN JAPANESE STUDIES

JAPANFOUNDATION \&

BRINGING JAPAN TO YOU

To link to this article:

https://doi.org/10.21159/nvjs.11.04

ISSN 2205-3166

New Voices in Japanese Studies is an interdisciplinary, peer-reviewed journal showcasing the work of emerging scholars with ties to Australia or New Zealand and research interests in Japan.

All articles can be downloaded free at newvoices.org.au

(c) The Japan Foundation, Sydney and Sonja Petrovic, 2019

\section{(c)} (c) (i) $(9$

This work is licensed under a Creative Commons Attribution-NonCommercialNoDerivatives 4.0 International License. 


\section{INTRODUCTION}

On March 11, 2011, at 14:46 JST, a magnitude 9.0 earthquake struck the northeast coast of Japan, marking the beginning of the triple disaster now known as 3.11. The Great East Japan Earthquake caused a succession of calamitous events, including a powerful tsunami of up to 40 meters in height and aftershocks that continued for more than a month. The tsunami devastated the coastal area of the northeastern Tohoku region and southern Hokkaido; it also caused damage to several nuclear reactors at the Fukushima Daiichi Nuclear Plant, resulting in the considerable emission of radioactive materials into the environment. The destruction of the nuclear plant was reported as the world's worst nuclear catastrophe since Chernobyl in 1986 (Okumura 2014), and required the immediate evacuation of citizens from surrounding areas. The earthquake and tsunami destroyed commercial and residential infrastructure, including roads, in many coastal municipalities, and over four million households lost access to electricity and water for several days.

The enormous scope of 3.11 meant that many individuals felt a disruption to the patterns of everyday life and their sense of security. This in turn triggered new interactions among individuals, reconfiguring their sense of social connection and communal belonging. Constant reporting on the disaster largely displaced the daily flow of regular broadcasts by major national and commercial mass media channels. Surrounded by images of the disaster and pessimistic news, many people turned to social media for support. Notably, a profound sense of distrust also developed amongst the public towards government and mainstream media institutions due to a lack of institutional guidance and credible information flow; communication gaps between local and central government, TEPCO and media institutions; and the release of contradictory reports (Funabashi and Kitazawa 2012; Hobson 2015). This led people to seek out alternative sources of information as the disaster was unfolding. In the context of the disaster-particularly regarding the nuclear meltdown and diffusion of radioactive material into the atmosphere-social media was perceived to be more credible and to offer more up-to-date information than the mass media was seen to provide. ${ }^{1}$

This article conceptualises 3.11 as three inter-related events: earthquake, tsunami and nuclear disaster, and differentiates between three main phases-during, immediately following the earthquake and tsunami, and immediately following the nuclear disaster-to explore how social media use generated new forms of affective communities.

\section{The Social Media Landscape in Japan}

One of the main characteristics of Japan's media landscape during 3.11 was the growing role of social media as an alternative platform for collecting and disseminating crucial information on the evolving disaster, mobilising help 
and encouraging community engagement and participation. Crucially, social media provided a space where individuals could connect with similarly affected others. Before the disaster, social media was predominantly used in Japan as a social networking tool for keeping in touch with family and friends, and keeping up with the flow of popular culture and relevant news (Kindstrand et al. 2016). Japan's first social media platform, Mixi, emerged in $2004 .{ }^{2}$ It started as a social networking service which enabled users to express themselves on blogs and profile pages, add friends and join communities in which they could share personal problems, similar interests or feelings that they could not talk about directly (Takahashi 2010). Mixi offers private and closed communication between people who are friends in real life. Similarly, the Japanese social media app Line serves to support the direct, interpersonal exchange of email and phone calls between existing friends. ${ }^{3}$ In contrast with these platforms, Twitter and Facebook facilitate content-sharing with a broader audience, thus making them more public than Line and Mixi.

Twitter was not widely used in Japan before 3.11, and the subscribers it did have tended to use it as a tool for social networking and sharing daily activities (Yoshitsugu 2011). Much of Twitter's success in Japan can be attributed to its relative anonymity, as it allows users to post daily thoughts or selfrelated messages and interact with other users without the need to reveal one's identity. Facebook arrived in Japan in 2008 but experienced slow user growth as it struggled to compete with homegrown social networks (and to some extent Twitter), which already dominated the social media landscape. Furthermore, the Facebook culture of using real names appeared to conflict with the cultural characteristics of social media users in Japan who tend to value personal privacy and avoid sharing too much background information on social media (Acar and Deguchi 2013). In yet another difference from Line and Mixi, Twitter and Facebook are perceived as media for storytelling which, through instant dissemination of content, invite individuals to engage with and experience events as they unfold, thus enabling users to imagine a sense of place and communal belonging (Papacharissi 2016).

A recent report shows that the most popular social media platform in Japan is YouTube, followed by Twitter, Line and Facebook (Newman et al. 2018). As a powerful content-based, online video-sharing social platform, YouTube is arguably aimed at developing new relationships and communities around similar interests and experiences by allowing individuals to subscribe to other users' channels and communicate through response videos, written comments and ratings of video content. The platform enables users to express themselves through rich combinations of audio and visual content, and tends to foster small communities where users cultivate close relationships with others (Rotman and Preece 2010).

In Japan, user motivations for engaging with social media changed significantly following the 3.11 disaster. Social media became a space to share anxieties and emotions, triggering volunteer recruitment and organisation 
of anti-nuclear protests and movements (Slater et al. 2012a). Facebook's policy of using real names enabled people to locate friends and family and find information on the disaster as it was unfolding, and Twitter was "one of the few functioning communication tools immediately after the earthquake" (Acar and Muraki 2011, 393), breaking the first news 20 minutes before the mainstream media. Furthermore, social media was utilised as a platform for initiating community and relief-oriented actions, some examples of which are discussed below.

\section{Theorising Affective Communities in a Disaster Context}

In contrast with the traditional notion of community, which is based on spatial proximity and face-to-face communication, online community is defined as a group of people who are drawn together by a shared purpose or a common interest and use online platforms "to interact and create usergenerated content that is accessible to all community members" (Rotman and Preece 2010,320). The ever-growing popularity of social media platforms shows that, in addition to online presence, people seek a sense of community, which emerges from shared emotional connections and experiencesincluding those precipitated by natural disasters and crises.

In a sociological context, media has been found to provide emotional support, as well as a sense of companionship and community for individuals who are faced with a crisis (Perez-Lugo 2004). Similarly, an examination of the role of blogs in crisis communication during hurricane Katrina argues that social media can serve as a space for emotional and therapeutic support, as it allows users to discuss and share their emotions online with other individuals (Macias et al. 2009). Overall, the social media environment enables people who have lived through similar experiences of a traumatising or disruptive nature to share their emotions online, thus significantly facilitating the coping process (Döveling 2015, 2017). Further, storytelling in the interconnected online environment facilitates a process of cathartic sharing, which allows individuals to work through the experience of trauma or crisis and opens up new opportunities for community-building (Arthur 2009). This leads to the emergence of affective communities in the digital environment, also conceptualised as 'digital affect cultures' (Döveling et al. 2018). Communicating with each other in these spaces, affective communities respond emotionally and empathically to similar others, creating a sense of belonging even among geographically distant individuals (Döveling et al. 2018, 5; see also Hjorth and Kim 2011). My study builds on work in this area by offering an in-depth examination of how a sense of communal belonging manifests across different social media platforms, exploring the experiences of social media users of Japanese nationality.

The emergent use of social media in Japan in the wake of the 3.11 disaster has been extensively explored in several studies, with a focus on Twitter as a critical communication tool (Acar and Muraki 2011; Hashimoto and Ohama 2014; Kaigo 2012) and its psychological effects on users in the 
disaster-affected areas (Matsumura et al. 2016; Umihara and Nishikitani 2013). These studies use similar methodological approaches: they either draw on surveys of users who resided in the disaster-stricken areas, or analyse their Twitter posts. While Slater et al. (2012a) have discussed how social media served as a space for the exchange of emotions and anxieties in the wake of the 3.11 disaster, their study is a chronological examination of social media use over different phases of the disaster which does not extensively explore how affective practices manifested at different levels of online communication. In contrast, my study combines analysis of social media use across multiple platforms with in-depth interviews, thereby contextualising user behaviour and providing a deeper understanding of social media's role in the context of disasters than can be gained from content analysis alone. Therefore, this study represents a significant addition to existing scholarship on the 3.11 disaster.

The study also contributes to knowledge in other areas. Since 2011, a considerable amount of research has emerged in the areas of disaster and emergency communication and digital media studies examining the role of Twitter in contexts of natural disaster, crisis and upheaval (e.g., Bruns et al. 2012; Bruns and Burgess 2011; Oh et al.2015; Papacharissi 2016; Sadri et al. 2018; Stieglitz et al. 2018). My study builds on this body of research by broadening the line of inquiry to encompass a wider range of social media platforms, both homegrown (Mixi, Line) and imported (Facebook, Twitter, YouTube). It uses the case of 3.11 to explicate the sense of communal belonging which evolved in the wake of disaster through the communication of emotional alignment and discursively constructed emotions, and demonstrates how this was variously fostered in different social media environments.

While material reconstruction has significant importance in the aftermath of disasters, it is also important to understand the social aspects of disasters, including how different media forms can aid recovery by strengthening connections with self, family and society. Online expression can be therapeutically beneficial as it facilitates the process of coping with trauma or crisis, thereby opening up opportunities for community building (Arthur 2009). On this basis, understanding the dynamics of social media use across a range of platforms may allow us to predict how people will adopt and utilise new communication tools to cope with disasters. Critically, considering that these tools are being increasingly relied upon in times of disaster (see Tomer et al. 2015), knowledge of how social media platforms can evoke or intensify a sense of communal belonging may have implications for how these platforms evolve to better support crisis-stricken communities in future. Furthermore, the study looks at participants who are based outside the directly affected regions and yet exhibit affective connections to them. Insights from less-affected social media users may be useful in helping charity and relief organisations to more successfully engage volunteers and donors to assist with relief efforts, as well as in understanding how different online communities can motivate financial donations for affected regions. 
This study employs open-ended, in-depth interviews to learn about participants' personal experiences through the stories they tell (Seidman 2012), and to understand the relationship between media and society (Brennen 2012). Before and during the fieldwork period, which extended from August to November 2017, I recruited 38 Japanese nationals to participate in interviews of 30-60 minutes' duration, in Tokyo (in spaces where participants felt comfortable), with the aim of understanding how the participants perceived and experienced a sense of communal belonging in relation to their social media use in the context of the 3.11 disaster. Interviews were conducted in person and in the Japanese language, without the help of an interpreter or third-party assistance. Face-to-face interviews enabled me to easily follow participants' narratives and adapt questions to investigate underlying meanings, giving participants the chance to elaborate on certain issues and clarify their answers (Kvale 2007). The face-to-face nature of the interaction also provided the opportunity to see participants' non-verbal cues, which can reveal messages or communicate someone's mood or attitude and thereby aid in further questioning and understanding of verbal responses.

All participants were recruited through the snowball sampling method, utilising personal and professional networks to reach some of the first participants who then provided referrals for further interviews. Participants from age 25 to 59 were included to ensure that the sample represented a broad cross-section of social media users. Considering that small sample sizes in qualitative research allow for richness of data and a variety of participants (Moser and Korstjens 2018), I intentionally selected participants differing in age, with the aim of providing diverse perspectives on social media use. Disasters do not select for demographics. I approached this study with this in mind, and was therefore careful to avoid focusing solely on younger users.

The majority of the participants are residents of Tokyo. Tokyo was selected as it was the city with the leading rate of mobile phone subscription in Japan, as well as the highest rate of mobile internet penetration (63.3\%) and secondhighest rate of internet penetration (71.9\%) around the time of the 3.11 disaster (Slater et al. 2012b, 98). Tokyo therefore fit well with this study's aim of reaching a segment of the Japanese population that is likely to have used social media and accessed news via mobile phones and the internet at the time of 3.11. In this way, I was also able to recruit participants who were comparatively less affected by the 3.11 disaster than people in the Tohoku region and southern Hokkaido, and who were less likely to have suffered personal losses and psychological trauma. ${ }^{4}$ Even so, interviewed participants from Tokyo and surrounding areas still felt the effects of the disaster (continuing aftershocks, concerns about radiation, infrastructure disruptions and food shortages) and utilised social media to find and disseminate information and connect with fellow users. 
The table in the Appendix provides basic demographic information for all interviewed participants, including information on the media platforms that the participants used in the three main phases of the 3.11 disaster. The article relies on findings obtained through interviews conducted with 38 participants, discussing the most representative examples (highlighted in the Appendix) to illustrate how social media evoked and amplified a sense of communal belonging in the context of the 3.11 disaster. I also collected social media content such as Facebook posts and comments, Twitter posts and YouTube videos and comments from participants who actively used social media during 3.11. This helped me to enrich and confirm interview findings. A directed approach to qualitative content analysis was employed to identify themes and patterns and offer descriptive evidence that is supportive of existing scholarly theory (Hsieh and Shannon 2005).

Given the nature of the snowball sampling method used for this study, the sample is not considered representative. A broader pool of participants will be needed for future studies that aim to gain a representative understanding of motivations for using social media in the 3.11 context. Timing might also represent a limitation of the study, affecting the accuracy and completeness of memory as the interviews were conducted six years after the disaster, in the period from August to November 2017. Further, while this study focuses on the positive uses and benefits of social media in a disaster context, it is important to acknowledge that negative aspects do exist. Social media's convenience, open access and lack of gatekeeping mean that the diffusion of rumours can be more rapid than in traditional mass media. These can cause significant confusion, as was the case with Twitter posts that spread unfounded rumours about chemically contaminated rain in the week following the 3.11 earthquake (Takayasu et al. 2015; see also Umejima et al. 2011). While a thorough examination of these issues is beyond the scope of this paper, they are examined in the abovementioned publications in the context of the 3.11 disaster, and more broadly in Arthur's (2009) examination of trauma and social media usage.

This study is a small but significant contribution to the growing literature on social media and disaster communication in Japan. In the context of the growing visibility (and arguably growing frequency) of natural disasters (Pantti et al. 2012) and the rapidly changing media environment, the significance of this study lies in its contribution to the literature on post-disaster recovery and resilience-building for future disasters through contextual analysis of social media usage and the implications that different social media platforms can have for an individual's sense of communal belonging.

\section{MULTI-LEVEL SOCIAL MEDIA USE DURING THE 3.11 DISASTER}

Döveling et al. (2018) break down social media use into three intersecting levels: micro, meso and macro. The article adopts this categorisation as the main framework for analysing how individuals in Japan during and immediately following the 3.11 disaster affectively engaged in digital space. 
The micro level is the most local and personal form of social media use, where emotional interaction occurs within the close circle of family and friends. In the case of 3.11, this refers to the exchange of messages related to safety confirmation immediately after the earthquake. Meso-level refers to less immediate emotional bonding among individuals within one community or a group over a specific theme or universal need, which in the case of 3.11 refers to the collective need for emotional support and shared feelings of togetherness on a regional level. Macro-level refers to collective dealing with emotions via online discourses-narratives, videos, hashtags, photosthereby encompassing a more global level of communication where social media users who do not know each other personally come together over a common theme, disaster or sentiment. ${ }^{5}$

Drawing on this multi-level model of social media use, I demonstrate how social media fostered a sense of communal belonging through the social sharing of emotions and emotional alignment during and immediately after the 3.11 disaster. This article focuses on active social media users to explore how they coped with the disaster, contacted friends and family, or shared their thoughts and feelings in digital space. The findings of this study shed light on the differing modes of participants' digital and affective engagement, examined through three analytical levels-micro, meso and macro-and their overlaps.

\section{Micro-Level: Safety Concerns and Local Actions}

Participants' responses related to media use immediately after the earthquake reveal that their priority was to reach family members and close friends to check their safety, and seek any available information to understand the severity and scope of the disaster. Due to phone congestion and problems with electricity, participants had difficulties reaching their families, turning instead to email and social media platforms to establish first contact and exchange local information and messages of support.

Online communication at the micro level refers to the private and local exchange of messages between individuals who are intimately connected as family members or close friends. During the 3.11 disaster, such interpersonal communication was facilitated by homegrown social networks Mixi and Line. Meanwhile, many participants found Facebook and Twitter to be efficient in instantly informing friends of their well-being and spreading local information on train delays and the availability of food supplies in supermarkets, in addition to general information on the earthquake. Participants' patterns of social media use immediately after the earthquake indicate that a sense of belonging at the micro level is formed in two ways: firstly, through sharing emotions online where similar experiences of the disaster evoke comparable emotional reactions between friends or family members, and secondly, through circulating local information to help friends or other users nearby

.


make more informed decisions about their actions.

The micro level of social media interaction is illustrated in a brief message exchange on Facebook between Chieko, one of the interviewed participants, and her friend, just a few hours following the earthquake. ${ }^{6}$ Unable to go back to Tokyo from Yokohama, and stranded in a hotel room, Chieko found Facebook particularly useful as the only way to contact family and friends. On March 11, 2011, Chieko received a message from her friend Keiko who posted on her Facebook timeline:

The earthquake was scary, and I'm now stuck here with a client until trains begin to move. Are you okay? ${ }^{7}$

(Chieko 2011)

Chieko briefly replied that she was in Yokohama and used an 'angry face' emoticon to express how she felt about the whole situation, after which her friend tried to console her by sharing local information and showing concern for Chieko's well-being:

Trains are starting to move in the city, but JR and other lines are still not operating. Please do not catch a cold! $!^{8}$

(Chieko 2011)

Some participants found Twitter useful for establishing first contact and disseminating local information. Shortly after the initial earthquake, apart from direct message exchange and safety confirmation, Toshi, one of the participants, utilised his Twitter feed to post photos from local convenience stores and circulate information on water shortages to other Twitter users living in the same district. Although Toshi mentioned that he was not very active in posting information on social media before the 3.11 disaster, he decided to utilise Twitter as a space to circulate vital local information following the earthquake, with the aim of helping others understand the situation and reduce panic:

For example, I went to a convenience store, and it was like, there was no water, so I took a photo which showed there was no water. It was not an everyday situation, so I posted it [on Twitter]. At that time, [bottled] water was out of stock [...]. The water supply had stopped and no-one could buy water; people panicked; that photo circulated and there were tweets about it on Twitter... ${ }^{9}$

(Toshi 2017)

Participants' media usage immediately after the earthquake also indicates that besides providing important information, different social media platforms served to fulfill participants' needs for belonging and social connection. The use of close-structured networks (Line and Mixi) facilitated the interpersonal exchange of safety-related information, indicating participants' need to 
connect with close ties. On the other hand, Facebook and Twitter, as grouporiented social networks, proved to be useful for updates about friends' situations and the dissemination of fundamental local information.

\section{Intersections of the Micro and Meso Levels}

In some cases, among participants who actively used social media to establish contact with friends and family, communication transcended the local level, intersecting with references to the affected region and implying a crossover of micro- and meso-level social media use, which this section examines in more detail.

To best illustrate the linkage of the micro and meso levels, I use the example of Hana, a participant from Osaka, who used Facebook solely to inform others about the disaster and establish contact with her friends. In addition to Line and regular email, through which she contacted family, Hana used Facebook updates to inform her friends that she was safe, to which they replied with messages of relief. In a message posted on Hana's Facebook timeline on March 13, 2011, two days after the earthquake, a friend expressed both relief in knowing that Hana was safe and concern for the people in the disaster zone, sending prayers for those directly affected by the earthquake and tsunami. Soon after receiving the message, Hana replied with a similar reference to those in the affected region, wishing for their safety: We are all safe. Hope everyone over there will overcome soon (Hana 2011). ${ }^{10}$ While this kind of online interaction happens on the interpersonal and familiar level between two friends who exchange messages to enquire about each other's safety, they both exhibit compassion for the affected region, which exceeds the micro level of online interaction. Through these Facebook posts, we see a shift from a local to a regional level of concern for affected communities, despite the users' geographical distance from them. This shift shows how a sense of communal belonging and feelings of connectivity emerge in digital space, blurring the boundaries between immediate and distant.

Another example of cross-level social media use is the case of Mei, who was based in Kobe at the time, and utilised Facebook to express concern and frustration about her inability to contact her father, as well as concern for people in the affected region. The extract below illustrates Mei's use of Facebook a day after the earthquake, on March 12, 2011.

\section{Extract 1. Mei's Facebook thread}

Mei: $\quad$ I'm really worried about my friend in Tokyo and people in the east part of Japan. Is everyone ok? I still can't contact my dad in Tokyo, aaaahhhh. I'm worried, and I can't sleep!!!!!!

東京のみんな〜大丈夫?関西でもゆれたけど、ニュースで破滅的 な影響をうけた東京を 心配している!!! ああ、私もまだお父さ んと連絡がとれなくて、心配で、眠れない!!!! 
Friend 1: I'm in Tokyo, but I'm okay!! It seems that phone lines are not working... Hope your dad is okay...makes you worry, doesn't it...

Friend 2: Hope you can contact your dad soon.

$(\text { Mei 2011) })^{11}$

In her first Facebook post after the earthquake, besides giving an update on her situation, Mei expresses equal concern for people from Tokyo, her local communities and "people in the east part of Japan" (i.e., people from the affected region). Mei's digital narrative indicates a shift in her sense of communal belonging from a personal, micro-level of concern for family and close friends to a meso-level of concern for the affected communities. Even though she is geographically far from the affected region, Mei shows a sense of connection, utilising her Facebook timeline as a space where she can convey her emotions across distance and feel like a part of a broader community. She thereby highlights the potential of social media to create affective connections and a sense of belonging even among geographically distant individuals (Döveling et al. 2018). At the same time, through sharing her feelings with friends on Facebook, Mei expresses the need to seek out similarly affected individuals who are also having problems contacting their families - in other words, others who are aligned with Mei's feelings and can provide compassion, solidarity and emotional support. In this way, Facebook serves not only as space for one-directional emotional communication where individuals vent personal feelings, but it also invites the affective attunement of other users who connect and align with a communicated event and express this through liking and commenting on a Facebook post, thereby creating affective publics (Papacharissi 2016). The concept of affective communities in digital space moves beyond the feelings of the individual to a broader consideration of the emotional flows and bonding between users online which generate digital affect cultures (Döveling et al. 2018).

The emotional bonding and empathic alignment within a familiar relationship, as illustrated in Hana's and Mei's case, makes it harder to separate the micro level from the meso level of belonging. They intersect and feed into each other, indicating that affective communities can be built on the intersections of shared feelings between friends and feelings of compassion toward distant yet similar others.

\section{Meso-Level: Evoking Belonging through Digital Narratives}

Digital narratives are essential for maintaining an individual's sense of community in the context of social media, where the individual imagines his/her membership in a broader community based on the reading or creating of narratives in digital space (Jones 2013). While many participants utilised social media to reach family and close friends immediately after the earthquake struck, others were strongly motivated to voice informational 
or emotional support through digital narratives within a community or a group, and use social media as a space for community engagement and participation.

Sana is one of the participants who actively used social media during the 3.11 disaster, mainly to share information with friends in Tokyo or to make more general updates in a Facebook group, informing people living outside Japan about the situation. She sees Facebook as space where she can find relief from anxiety through reading friends' supportive messages and comments (Sana 2017). In a message that she posted on Facebook on March 21, 2011, Sana invited her friends to join her in organising a local event:

I am thinking about organising a charity event at the hula dance club. This is still just an idea, but I wonder if there's anything that we too can do. ${ }^{12}$

(Sana 2011)

Some of her friends commented on the post, expressing their interest in joining the event. This meso-level of digital engagement is a significant shift from the immediate need to contact family and close friends to a broader need to find concrete ways of supporting affected communities, thereby fostering community engagement and participation through social media use.

More consistent usage of social media during the 3.11 disaster is seen in the case of Hiroshi, who actively utilised his Facebook timeline as a diary to document his experience of the disaster, share positive thoughts and motivational messages, and shift his mind from the anxiety caused by the constant exposure to news about the disaster. Hiroshi's narratives illuminate the distinct role of social media in comparison with mass media, with reference to their ability to provide access to local information, facilitate social interaction with similar others and offer relief from the depressing atmosphere which dominated television news (Hiroshi 2017). During and following the disaster, social media offered an alternative space for Hiroshi which contained hope and positive comments, as all users that commented on his posts across the platforms where he was active expressed the same or similar sentiments as he did. Hiroshi notes that one of the most significant changes in his social media use post-3.11 was the posting of encouraging messages on Facebook and Twitter, and videos on YouTube, prompted by an overwhelming need to help and engage in digital space:

I stopped watching TV so there was only SNS, but I began to use it differently as I wasn't just collecting information but started posting it myself. That's probably because of the fact that everyone experienced that earthquake. I knew there were so many things that all of Japan wanted to say, so I wanted to help, and I had so many different feelings... ${ }^{13}$

(Hiroshi 2017) 
In some of his first Facebook posts from March 11, besides some general updates about the earthquake and his situation, Hiroshi exhibits a sense of compassion for the affected region, wondering if people in Miyagi prefecture are safe and hoping that there are no casualties. In another post, he empathically aligns with the affected region: "I feel weak and depressed because it is cold. How are people in Miyagi spending the night?" (Hiroshi 2011). ${ }^{14}$

Furthermore, Hiroshi turned to Facebook and Twitter to encourage community engagement and participation by inviting his friends and followers to make small donations and support the people of Tohoku. Here we see Facebook and Twitter used as action-oriented social platforms, where individuals initiate help, seek donations and promote engagement in local actions. Hiroshi's digital narratives, enriched with flows of affect and emotional resonance with regional communities, show how everyday social media platforms such as Facebook can be utilised to experience a sense of belonging and social connectedness and generate affective communities through storytelling in digital space.

\section{Hashtags: Intersections of the Regional and Global Level of Belonging}

A hashtag always starts with the hash sign "\#”, followed by a word or a combination of two or three words. Hashtags serve to mark the topic of a social media post and function to consolidate messages on the same topics for easy searchability (Murzintcev and Cheng 2017). Hashtags can be used to alert others to an individual's emotions and experiences, and can evoke feelings of closeness and solidarity between users based on shared experience of an event, including natural disasters, national crises, terrorist incidents and protests. Adding hashtags to social media posts can indicate a user's sense of connection with an event, or the desire to be recognised as a part of a community of users who use the same hashtag (Summerville 2018).

In a disaster context, one of the most effective ways to disseminate information to the public and respond to urgent needs and requests is through standardised and unified hashtags that are introduced and used by government and aid organisations. During the 3.11 disaster, besides the mobilisation of help and relief operations through hashtags like $\# j_{-} j_{-}$helpme or \#anpi, the hashtag \#prayforjapan also went viral, unifying compassionate messages, condolences and prayers sent by and to users in the disaster zone from across Japan and abroad. ${ }^{15}$ Since its emergence with the 3.11 disaster, the "prayfor" hashtag has become a social media norm internationally as a universal, compassionate response to disasters, crises, terrorist attacks and so forth.

On a few occasions, Hiroshi attached the hashtag \#prayforjapan to his Facebook narratives to express his gratitude for the encouraging messages coming from all over the world to Japan. Hiroshi's use of the hashtag indicates 
the intersection of meso- and macro-level online communication, as the use of \#prayforjapan signifies shared feelings of grief and emotional belonging on a more global level, helping users find 'similar others' beyond their circle of friends.

The case of Hiroshi is an excellent example of how everyday social media platforms such as Facebook can manifest affective communities, where the individual feels a sense of belonging to a community through writing a digital narrative for a close circle of friends or other intended audience. At the same time, through continuous use of the hashtag \#prayforjapan, Hiroshi's use of social media extends beyond the interpersonal level of communication to the global level of emotional flows, connecting individuals across the world and thus showing how social media can facilitate the emergence of global affective communities in response to disaster. Moreover, the recurring use of the English-language hashtag \#prayforjapan in the context of more recent Japanese natural disasters (such as the floods of July 2018 and the Hokkaido earthquake in September of the same year) indicates that Japanese users continue to embrace this trend as a way of spreading information about disasters to communities beyond Japan's borders. ${ }^{16}$

The following section uses the example of a YouTube community, formed in the immediate aftermath of the 3.11 disaster, as a case study, to show the potential of social media to enable individuals who are geographically dispersed and do not know each other in person to experience a sense of belonging to a global community. It is here that I explicate the significance of the final level of social media-the macro-in the 3.11 disaster context.

\section{Case Study: A 3.11 YouTube Community}

In addition to Facebook and Twitter, Hiroshi utilised his YouTube channel to post videos featuring his own piano music, which he composed regularly. He posted six videos of his own piano compositions on his YouTube channel over the period from March 12 to March 18, 2011, with an additional video posted on March 11, 2013 in commemoration of the second anniversary of the disaster. In the brief introduction below the first video, posted a day following the earthquake, Hiroshi dedicated the video to the people of the affected region and the whole of Japan in the hope that it would offer them some relief, as he explains:

If I can help you find inner peace, just a little, I will be happy. Please do not push yourself and please rest well. ${ }^{17}$

(Hiroshi 2011)

This comment also highlights that Hiroshi's digital engagement was to some extent driven by a desire to support affected communities and spread awareness of the 3.11 disaster through personalised social media use, which, 
in his case, combines various social media platforms with self-generated video content and digital diarising.

Additionally, in his initial video, Hiroshi states that all advertising revenue from YouTube will go to charity to support the reconstruction in the Tohoku region. This shows that he also utilised YouTube as an action-oriented platform by seeking and collecting donations for affected communities. Hiroshi's videos received a high number of views and likes from Japanese and worldwide users alike, who subscribed to his YouTube channel and commented below his videos, voicing their compassion for the people of Japan and the affected region. In this way, YouTube, as a digital social media platform, facilitated online interaction and discussion, fostering feelings of togetherness and solidarity, and served as a platform for the public display of care, emotions and affective attunement.

Table 1 provides an overview of Hiroshi's videos, including their publication date and information about the general outreach of each video (dislikes, likes, number of views and comments).

Table 1: Overview of Hiroshi's YouTube Videos

\begin{tabular}{|c|c|c|c|c|c|}
\hline Video & Publication Date & Dislikes & Likes & $\begin{array}{c}\text { Number of } \\
\text { Views }\end{array}$ & $\begin{array}{c}\text { Total no. of } \\
\text { Comments }\end{array}$ \\
\hline Video 1 & March 12, 2011 & 3 & 149 & 76,813 & 76 \\
\hline Video 2 & March 13, 2011 & 3 & 57 & 17,498 & 12 \\
\hline Video 3 & March 14, 2011 & 1 & 31 & 8,927 & 4 \\
\hline Video 4 & March 15, 2011 & 0 & 75 & 17,993 & 15 \\
\hline Video 5 & March 16, 2011 & 41 & 1,400 & 773,599 & 149 \\
\hline Video 6 & March 18, 2011 & 0 & 42 & 4,010 & 25 \\
\hline Video 7 & March 11, 2011 & 0 & 20 & 1,004 & 10 \\
\hline
\end{tabular}

\section{Macro Level of Belonging}

To further explore how a sense of community was generated and sustained in this series of YouTube videos, I coded users' comments on six videos posted by Hiroshi in 2011. The coded data revealed repeated patterns in the way users reacted to the video and communicated with other users or Hiroshi. The data illustrates multi-directional online interaction, giving users the opportunity to feel a sense of belonging to a community of fellow users through watching the same video and sharing emotional support. Hiroshi's YouTube channel reflects the central idea of a shared purpose or common interest that fosters online communities (Rotman and Preece 2010), which in this case refers to posting user-generated videos, subscribing to the same channel or communicating through written comments. 
The first pattern emerging from users' comments reveals that some users immediately shared Hiroshi's videos on other social media platforms or blogs with the aim of reaching a wider audience, like user H.T.:

I'm late, but I wanted to share the video with as many people as possible, so I introduced it on my blog today. Thank you very much! $!^{18}$

(User H.T. 2011)

This comment suggests that other users utilised their social media accounts or blogs as action-oriented platforms for mobilising support, sharing Hiroshi's YouTube video to circulate awareness of the disaster and invite their friends, followers and other users to engage in collecting donations for the affected region. The digital engagement between Hiroshi as the content creator and other YouTube users, while generating only a small number of donations, indicates a significant shift from utilising YouTube as a space of everyday entertainment to using it as a platform for initiating action and practical support. This phenomenon may not be unique to YouTube, as Facebook and Twitter offer similar potential for mobilising support in a disaster context. However, the literature examined earlier in this paper suggests that the macrolevel of online communication facilitated by YouTube may have allowed its users to reach a wider audience than Facebook and Twitter. Moreover, the combination of sentimental piano music and disaster images in Hiroshi's videos were arguably more compelling for some users than written text alone, thus motivating users to share the content and take action.

The second pattern which emerged from coding is the users' empathic alignment with the affected region, regardless of being geographically distant from it. Solnit (2009) argues that disaster, as a shared experience of loss, danger and uncertainty, often creates emotional solidarity and empathy among affected individuals. In doing so, it creates altruistic communities, where individuals respond with an enhanced need to help and engage in the community as members of the same society that is threatened by the disaster (Solnit 2009). In the case of the YouTube community in the context of the 3.11 disaster, users who commented on Hiroshi's videos and interacted with other users online were not necessarily affected by the earthquake, tsunami or nuclear disaster, but they emotionally identified with the experience of the disaster. This emotional alignment of users from all over the world and across Japan suggests the potential of social media to facilitate the emergence of affective communities on a global level, creating a sense of belonging among individuals despite their geographical distance from one another.

User M.B. commented on the first video which Hiroshi posted on March 13, 2011, expressing compassion for the affected region by saying that she cried after she heard about the disaster victims, even though she lives outside of Japan. Her contribution to the affected communities was through supportive and positive messages. As Döveling (2015) observes, emotional support communicated in digital space "may provide an alternative to traditional support channels [for individuals] confronting similar challenges" (106). In reply to User M.B., Hiroshi explains how emotional support from 
other users helped him to feel less lonely immediately after the earthquake, as he became aware that others were going through similar emotional struggles.

The third pattern which emerged from the analysis is users' sense of closeness with other members of the YouTube community. For example, on March 13, 2011, one of the users shared updates on earthquake intensity and aftershocks via comments on Hiroshi's YouTube channel, evoking feelings of collective belonging:

The Meteorological Agency has issued a probability of 70\% that aftershocks with a magnitude of 6 will occur within three days from March 13. Everyone, please take care of each other! ${ }^{19}$

(User S. 2011)

In this way, User S. can be seen to perceive YouTube as a space where people unite as similarly affected members of the same community who need informational and emotional support. This case shows that, in addition to transmitting vital information for individuals who are geographically close to the affected region, social media can also serve to circulate emotional support for those experiencing the same disaster. Similarly, user K. expressed his affinity for one of Hiroshi's videos, and reminded other users that people in the disaster area were still suffering and should not be forgotten, thus indicating that he feels like a member of the affected communities that he 'invites' other users to empathically align with.

The fourth pattern is seen in the way that users communicate feelings of solidarity and compassion through prayers in digital space (see Extract 2). These served a similar purpose to the commemorative hashtag \#prayforjapan, generating feelings of togetherness and signifying connection with the event. The prayers that users posted on YouTube imply the users' collective need and desire for companionship and support, showing how this social media platform became an outlet where users exhibited helpfulness through the public display of care.

Extract 2. Examples of User Prayers Posted under Hiroshi's YouTube Videos

User S.I.: $\quad$ I'm praying for Japan.

User M.E: I just lit a candle and prayed! Japan is not alone!

User K.A.: I pray for peace in Japan. Everyone in Japan, please don't give up! ${ }^{20}$

Expression of emotions, or affect, in the digital realm at a global level can be understood as anonymous emotional bonding, where communities of strangers are brought together around the bonds of sentiment and emotional attachment (Döveling et al. 2018; Papacharissi 2016). In the aftermath of 3.11, the digital, interactive environment of YouTube enabled individuals to interpret their most fundamental feelings of sadness, relief or anger and share them with similar others, thus creating a sense of togetherness and affective attunement with other users, and generating global affective communities. 
This article examined the potential of social media to foster a sense of communal belonging and generate new forms of affective communities in digital space, using the case study of the 3.11 disaster. The findings suggest that social media use is linked to the individual's sense of community, with online communication moving across levels and platforms and specific features of social media. Research has shown that feelings of togetherness and solidarity manifested on social media are ephemeral, and can fade and transform over time (Thomas et al. 2018). In my study, participants' reflections on their social media use suggest that the short-term, ephemeral sense of communal belonging was intensified in the immediate aftermath of the 3.11 disaster, but without strong continuity in the following days. In the case of Hiroshi, the only participant who was already a regular social media user at the time of 3.11, we can see a more consistent use of social media throughout all three phases of the 3.11 disaster. While an examination of this phenomenon is beyond the scope of this paper, more research is necessary to provide in-depth understanding of how a sense of communal belonging is maintained in digital space, and how it changes or fades over time.

For private, interpersonal exchanges of safety-related information, participants used Mixi and Line, while Facebook and Twitter, as group-oriented social networks, proved to be useful for updates about friends' situations and the dissemination of local information. The findings indicate that a sense of belonging at the micro-level was formed through emotional online discourses within each user's circle of family and friends, where social media served as a relief from anxiety immediately after the earthquake. Participants exhibited both local and regional levels of belonging, as they empathically aligned with the affected region despite being geographically far from it, thereby indicating a shift in participants' sense of belonging from the personal to a regional level of concern for affected communities. Furthermore, in the aftermath of the 3.11 disaster, social media was utilised as a platform for initiating community and relief-oriented actions. In this way, to some extent social media can be said to have redesigned individuals' sense of place and belonging during the disaster and its aftermath, at the same time as people's material spaces and positions in communities were being reconfigured due to emergency evacuation.

My findings regarding the meso level of online communication in the wake of the 3.11 disaster highlight the potential of Facebook and Twitter to transcend spatial and temporal barriers, enabling emotional bonding between individuals through reading or sharing digital narratives. Due to its interactive nature and ability to cross spatial boundaries, social media facilitated the emergence of different emotional flows and amplified feelings of togetherness, leading to the emergence of affective communities. In the post-3.11 context of social media use, participants' narratives highlight the changing role of Facebook from an everyday social networking tool to an online emotional space of interaction, collectivity and transmission of emotions. 
Participants' use of the hashtag \#prayforjapan on Twitter and Facebook highlighted how social media use generated feelings of community, alluding to a collective need for companionship and mutual support, as hashtags helped users find similar others beyond their circle of friends. The use of the hashtag \#prayforjapan not only facilitated flows of emotional and supportive messages, but it encouraged individuals to take action to provide relief for affected communities and spread awareness of the national struggle, as Hiroshi's case illustrates.

Hiroshi's case also shows how YouTube facilitated the global alignment and affective attunement of users, allowing him to build a community of users who were drawn together by shared experience of the disaster and a fundamental need for psychological comfort and social togetherness, regardless of geographical distance. Besides providing a platform for emotional support, YouTube also offered a way to initiate financial donations, as video advertisement revenues were turned into charitable donations for the affected region. This shows that YouTube can be utilised as an effective action-oriented platform, rather than just an outlet for public displays of affect. The macro level of online communication harnesses the power of social media to establish global affective communities. In this context, YouTube became an outlet for expressing solidarity and aligning emotions globally through supportive and emotional discourse, prayers, and symbols of solidarity such as hashtags.

\section{CONCLUSION}

This article has sought to examine how social media use generated new forms of affective communities in Japan in the context of the 3.11 disaster. I have shown how social media use fostered a sense of communal belonging in the immediate aftermath of the 3.11 disaster, even among geographically distant individuals. This sense of communal belonging was formed through a combination of user consumption and production of media content, and the potential of social media to enable users to meet similar others. The Japanese case study confirms existing findings in media literature regarding social media use during disasters and the manifestation of affective communities in digital space. These communities developed through emotive online discourses, empathic alignment with the affected region, and the activation of a sense of communal belonging in geographically dispersed individuals. Social media facilitated multi-level online communication and interaction, serving a kaleidoscope of needs for disaster communication, local action, psychological comfort and social togetherness.

Additionally, the Japanese case study sheds light on a new kind of online sociality among Japanese social media users, moving beyond the private, one-on-one communication supported by homegrown socia media platforms to the more open and group-oriented online communication fostered by Facebook, Twitter and YouTube. In the context of the 3.11 disaster, these social media platforms generated affective communities and supported free

\section{IN JAPANESE STUDIES}


articulation of emotions, thus helping individuals cope with the disaster, initiate collective action and build community consciousness. Future research should address the problem of the ephemerality of social media by examining commemorative practices and the ways in which individuals who remember 3.11 maintain or do not maintain their sense of community, and whether the emotional alignment and sense of solidarity gradually disappear in the reestablishment of everyday life.

\section{APPENDIX: BASIC DEMOGRAPHIC INFORMATION ABOUT PARTICIPANTS IN THIS STUDY}

\begin{tabular}{|c|c|c|c|c|c|}
\hline $\begin{array}{l}\text { Name } \\
\text { (Pseudonym) }\end{array}$ & Gender & Age Group & $\begin{array}{l}\text { City } \\
\text { (Present- } \\
\text { day) }\end{array}$ & $\begin{array}{l}\text { City/Region } \\
\text { (3.11) }\end{array}$ & Media Use (3.11) \\
\hline Ayumi & Female & $30-39$ & Tokyo & outside Japan & News websites; TVs \\
\hline Ayako & Female & $40-49$ & Tokyo & Tokyo & TV; news websites; Facebook \\
\hline Chieko & Female & $40-49$ & Tokyo & Tokyo & Facebook; TV \\
\hline Atsushi & Male & $40-49$ & Tokyo & Tokyo & TV; Facebook; Line \\
\hline Daichi & Male & $40-49$ & Tokyo & Tokyo & TV; Facebook; news websites \\
\hline Eiji & Male & $30-39$ & Tokyo & Tokyo & Facebook; TV; news websites \\
\hline Fuji & Female & $50-59$ & Tokyo & Kawasaki & TV; news websites \\
\hline Hideki & Male & $20-29$ & Tokyo & Fukushima & TV; Twitter; YouTube; 2channel* \\
\hline Hiro & Male & $30-39$ & Tokyo & Tokyo & Twitter; Facebook; Line; news websites \\
\hline Hana & Female & $40-49$ & Osaka & Osaka & News websites; Facebook; Line; TV \\
\hline Kenjirōō & Male & $50-59$ & Tokyo & Gunma & Radio; TV; news websites \\
\hline Kaori & Female & $50-59$ & Tokyo & Tokyo & TV; news websites \\
\hline Naoki & Male & $40-49$ & Chiba & Yonezawa & TV; news websites \\
\hline Toshi & Male & $20-29$ & Tokyo & Tokyo & Twitter; news websites; TV \\
\hline Yoshi & Male & $30-39$ & Tokyo & Fukuoka & TV; news websites; Twitter \\
\hline Naoko & Female & $30-39$ & Tokyo & Tokyo & Line; TV; Facebook \\
\hline Mei & Female & $20-29$ & Tokyo & Kobe & Facebook; Twitter; Line \\
\hline Kensuke & Male & $40-49$ & Tokyo & Tokyo & TV; Mixi; news websites \\
\hline Hiroshi & Male & $30-39$ & Tokyo & Tokyo & TV; Facebook; Twitter; YouTube \\
\hline Ryota & Male & $50-59$ & Tokyo & Tokyo & TV; news websites \\
\hline Kenta & Male & $20-29$ & Tokyo & Tokyo & TV; Line; news websites \\
\hline Mayumi & Female & $30-39$ & Melbourne & Tokyo & TV; Line; Facebook \\
\hline Miyuki & Female & $20-29$ & Tokyo & Tochigi & Newspaper; TV; news websites \\
\hline Masayuki & Male & $40-49$ & Tokyo & Tokyo & News websites; Facebook; TV \\
\hline Sana & Female & $20-29$ & Tokyo & Tokyo & Facebook; Twitter; Line \\
\hline Saki & Female & $30-39$ & Tokyo & Tokyo & News websites; TV; Twitter; Facebook \\
\hline Shinji & Male & $30-39$ & Melbourne & Tokyo & TV; news websites; Twitter \\
\hline Haruna & Female & $50-59$ & Tokyo & Tokyo & TV \\
\hline Takuya & Male & $40-49$ & Tokyo & Saitama & TV; YouTube; Facebook \\
\hline Kazuya & Male & $40-49$ & Tokyo & Tokyo & TV; news websites \\
\hline Takahiro & Male & $50-59$ & Tokyo & Tokyo & TV \\
\hline Takashi & Male & $20-29$ & Tokyo & outside Japan & News websites; Facebook; Twitter; YouTube \\
\hline
\end{tabular}




\begin{tabular}{|l|l|l|l|l|l|}
\hline Momoko & Female & $50-59$ & Tokyo & Tokyo & TV \\
\hline Tomoki & Male & $20-29$ & Tokyo & Nagano & TV; news websites; newspapers \\
\hline Rika & Female & $30-39$ & Kyoto & Kyoto & Radio; TV; Facebook; Mixi \\
\hline Wataru & Male & $30-39$ & Tokyo & Tokyo & TV; news websites \\
\hline Yumi & Female & $20-29$ & Tokyo & Nara & TV; Facebook \\
\hline Michiko & Female & $20-29$ & Tokyo & Kanagawa & TV; newspaper; news websites \\
\hline
\end{tabular}

Note: All user names are pseudonyms. Highlighting indicates participants who are discussed in this paper. In the 'Media Use' column, media sources are listed in the order of their importance to the individual user as an information source in the immediate aftermath of the 3.11 disaster.

* 2channel (2ちやんねる) is an anonymous online Japanese textboard community that was established in 1999.

\section{LIST OF INTERVIEWS CITED}

Toshi. 2017. Interview by author. Digital recording in Japanese. September 23.

Sana. 2017. Interview by author. Digital recording in Japanese. October 6.

Hiroshi. 2017. Interview by author. Digital recording in Japanese. October 27.

\section{LIST OF SOCIAL MEDIA CONTENT CITED}

Chieko. 2011. Facebook thread (“Jishin kowakatta desu ga... [地震怖かったですが、今 会社でお客…”), 11 March. Accessed 10 November, 2017.

Hana. 2011. Facebook thread ("We are all safe..."), 13 March. Accessed 15 November, 2017.

Mei. 2011. Facebook thread (“I'm really worried about my friends in Tokyo..."), 12 March. Accessed 10 October, 2017.

Sana. 2011. Facebook post (“Furadansu sākuru de, charitī ibento ‥ [フラダンスサーク ルで、チャリティーイベント…””), 21 March. Accessed 15 October, 2017.

Hiroshi. 2011. Facebook post (“Kanari tairyoku mo naku... [かなり体力もなく …”), 11 March. Accessed 15 November, 2017.

Hiroshi. 2011. YouTube post (“Sukoshi de mo, kokoro no heian... [少しでも、心の平 安…]”), 12 March. Accessed 15 November, 2017.

User H.T. 2011. YouTube post (“Osoku narimashita ga... [遅くなりましたが...]”), 27 March. Accessed 16 November, 2017.

User S. 2011. YouTube post (“13-nichi kara 3-nichi inai... [13日から3日以内...]”), 13 March. Accessed 15 November, 2017. 


\section{REFERENCES}

Acar, A. and A. Deguchi. 2013. "Culture and Social Media Usage: Analysis of Japanese Twitter Users." In International Journal of Electronic Commerce Studies 4 (1): 21-32. https://doi.org/10.7903/ijecs.989.

Acar, A. and Y. Muraki. 2011. "Twitter for Crisis Communication: Lessons Learned from Japan's Tsunami Disaster." In International Journal of Web Based Communities, 7 (3): 392-402. https://doi.org/10.1504/IJWBC.2011.041206.

Akioka, S., N. Kato, Y. Muraoka and H. Yamana. 2010. "Cross-Media Impact on Twitter in Japan." In Proceedings of the 2nd International Workshop on Search and Mining User-Generated Contents, 30 October, Toronto. 111-18. Accessed 10 May, 2018. https://dl.acm.org/citation.cfm?id=1871985 \&picked=prox.

Arthur, P. 2009. “Trauma Online: Public Exposure of Personal Grief and Suffering." Traumatology, 15 (4): 65-75. https://doi.org/10.1177/1534765609350781.

Brennen, B. S. 2012. Qualitative Research Methods for Media Studies: An Introduction. London: Taylor and Francis Group. https://doi.org/10.4324/9781315435978.

Bruns, A. and J. Burgess. 2011. "Local and Global Responses to Disaster: \#eqnz and the Christchurch Earthquake." In Disaster and Emergency Management Conference, Conference Proceedings, edited by P. Sugg, 86-103. Accessed 20 February, 2017. https://eprints.qut.edu.au/50739/.

Bruns, A., J. Burgess, K. Crawford and F. Shaw. 2012. \#qldfloods and @QPSMedia: Crisis Communication on Twitter in the 2011 South East Queensland Floods. ARC Centre of Excellence for Creative Industries and Innovation, Queensland University of Technology, Brisbane. Accessed 20 February, 2017. https://eprints.qut.edu.au/48241/.

Döveling, K. 2015. "Emotion Regulation in Bereavement: Searching for and Finding Emotional Support in Social Network Sites." New Review of Hypermedia and Multimedia 21 (1-2): 106-22. https://doi.org/10.1080/13614568.2014. 983558.

. 2017. "Online Emotion Regulation in Digitally Mediated Bereavement: Why Age and Kind of Loss Matter in Grieving Online." Journal of Broadcasting and Electronic Media 61 (1): 41-57. https://doi.org/10.1080/088 38151.2016.1273926.

Döveling, K., A. Harju and D. Sommer. 2018. "From Mediatized Emotion to Digital Affect Cultures: New Technologies and Global Flows of Emotion." Social Media + Society 4 (1): 1-11. https://doi.org/10.1177/2056305117743141.

Funabashi, Y. and K. Kitazawa. 2012. "Fukushima in Review: A Complex Disaster, a Disastrous Response.” Bulletin of the Atomic Scientists 68 (2): 9-21. https:// doi.org/10.1177/0096340212440359.

Hashimoto, Y. and A. Ohama. 2014. "The Role of Social Media in Emergency 
Hjorth, L. and K. Y. Kim. 2011. "The Mourning After: A Case Study of Social Media in the 3.11 Earthquake Disaster in Japan." Television and New Media 12 (6): 552-59. https://doi.org/10.1177/1527476411418351.

Hobson, C. 2015. "Rebuilding Trust after Fukushima." Fukushima Global Communication Programme Working Paper Series 4 (March): 1-7. United Nations University Institute for the Advanced Study of Sustainability.

Hsieh, H. F. and S. E. Shannon. 2005. "Three Approaches to Qualitative Content Analysis." Qualitative Health Research 15 (9): 1277-88. https://doi. org/10.1177/1049732305276687.

Jones, S. G. 2013. “The Internet and its Social Landscape.” In Virtual Culture: Identity and Communication in Cybersociety, edited by S. G. Jones, 18-41. London: SAGE Publications.

Kaigo, M. 2012. "Social Media Usage During Disasters and Social Capital: Twitter and the Great East Japan Earthquake." Keio Communication Review 34 (1): $19-35$.

Kindstrand, L., K. Nishimura and D. H. Slater. 2016. "Mobilizing Discontent: Social Media and Networked Activism Since the Great East Japan Earthquake." In Routledge Handbook of New Media in Asia, edited by L. Hjorth and O. Khoo, 53-65. New York: Routledge.

Kvale, S. 2007. Doing Interviews. London: Sage Publications. https://oi.org/ $10.4135 / 9781849208963$.

Macias, W., K. Hilyard and V. Freimuth. 2009. "Blog Functions as Risk and Crisis Communication During Hurricane Katrina." Journal of ComputerMediated Communication, 15: 1-31. https://doi.org/10.1111/j.1083-6101. 2009.01490.x.

Matsumura, N., A. Miura, M. Komori and K. Hiraishi. 2016. "Media and Sentiments in the Great East Japan Earthquake Related Tweets-Social Media as Meta Media." In 2016 IEEE Tenth International Conference on Semantic Computing (ICSC), 465-70. Accessed 25 May, 2019. https://doi.org/10.1109/ ICSC.2016.84.

Moser, A. and I. Korstjens. 2018. "Series: Practical Guidance to Qualitative Research. Part 3: Sampling, Data Collection and Analysis." European Journal of General Practice 24 (1): 9-18. https://doi.org/10.1080/13814788.2017.1375091.

Murzintcev, N., and C. Cheng. 2017. “Disaster Hashtags in Social Media.” International Journal of Geo-Information 6 (7): 1-17. https://doi.org/10.3390/ijgi6070204.

Newman, N., R. Fletcher, A. Kalogeropoulos, D. Levy and R. K. Nielsen. 2018. Reuters Institute Digital News Report. Reuters Institute for the Study of Journalism, University of Oxford. Accessed 15 January, 2019. http://media.digitalnewsreport.org/wp-content/uploads/2018/06/digitalnews-report-2018.pdf. 
Oh, O., C. Eom and H. R. Rao. 2015. "Research Note-Role of Social Media in Social Change: An Analysis of Collective Sense Making During the 2011 Egypt Revolution.” Information Systems Research 26 (1): 210-23. https://doi. org/10.1287/isre.2015.0565.

Okumura, H. 2014. “The 3.11 Disaster and Data." Journal of Information Processing 22 (4): 566-73. https://doi.org/10.2197/ipsjjip.22.566.

Pantti, M., K. Wahl-Jorgensen and S. Cottle. 2012. Disasters and the Media. New York: Peter Lang.

Papacharissi, Z. 2016. "Affective Publics and Structures of Storytelling: Sentiment, Events and Mediality." Information, Communication \& Society 3 (19): 307-24. https://doi.org/10.1080/1369118X.2015.1109697.

Perez-Lugo, M. 2004. "Media Uses in Disaster Situations: A New Focus on the Impact Phase." Sociological Inquiry 74 (2): 210-25. https://doi.org/10.1111/ j.1475-682X.2004.00087.x.

Rotman, D. and J. Preece. 2010. “The 'WeTube' in YouTube-Creating an Online Community through Video Sharing." International Journal of Web Based Communities 6 (3): 317-33. https://doi.org/10.1504/IJWBC.2010. 033755 .

Sadri, A. M., S. Hasan, S. V. Ukkusuri and M. Cebrian. 2018. "Crisis Communication Patterns in Social Media During Hurricane Sandy.” Transportation Research Record 2672 (1): 125-37. https://doi.org/10.1177/0361198118773896.

Seidman, I. 2012. Interviewing as Qualitative Research: A Guide for Researchers in Education and the Social Sciences, 4th edn. New York: Teachers College Press.

Slater, D. H., K. Nishimura and L. Kindstrand. 2012a. "Social Media, Information and Political Activism in Japan's 3.11 Crisis.” The Asia-Pacific Journal: Japan Focus, 10 (24): 1-31.

Slater, D. H., K. Nishimura and L. Kindstrand. 2012b. "Social Media in Disaster Japan." In Natural Disaster and Nuclear Crisis in Japan: Response and Recovery after Japan's 3/11, edited by J. Kingston, 94-108. London and New York: Routledge.

Solnit, R. 2009. A Paradise Built in Hell: The Extraordinary Communities That Arise in Disaster. New York: Viking.

Stieglitz, S., D. Bunker, M. Mirbabaie and C. Ehnis. 2018. "Sense-Making in Social Media during Extreme Events." Journal of Contingencies and Crisis Management 26 (1): 4-15. https://doi.org/10.1111/1468-5973.12193.

Summerville, M. 2018. “\#community: Hashtags Generate a Sense of Belonging." Debating Communities and Social Networks 2018 OUA Conference, April 23. Curtin University. Accessed 28 August, 2018. http://networkconference. netstudies.org/2018OUA/2018/04/23/community-hashtags-generate-asense-of-belonging/.

(1)

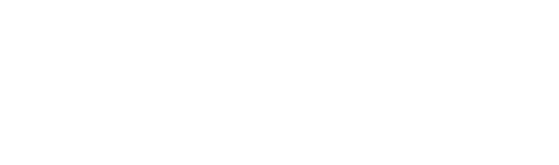

. 
Takahashi, T. 2010. "MySpace or Mixi? Japanese Engagement with SNS (Social Networking Sites) in the Global Age." New Media and Society 12 (3): 453-75. https://doi.org/10.1177/1461444809343462.

Takahashi, T. 2014. "Youth, Social Media and Connectivity in Japan." In The Language of Social Media: Identity and Community on the Internet, edited by P. Seargeant and C. Tagg, 186-207. London: Palgrave Macmillan.

Takayasu, M., K. Sato, Y. Sano, K. Yamada, W. Miura and H. Takayasu. 2015. "Rumor Diffusion and Convergence During the 3.11 Earthquake: A Twitter Case Study." PLoS one 10 (4): e0121443. https://doi.org/10.1371/journal.pone. 0121443.

Thomas, E., N. Cary, L. Smith, R. Spears and C. McGarty. 2018. “The Role of Social Media in Shaping Solidarity and Compassion Fade: How the Death of a Child Turned Apathy into Action but Distress Took It Away." New Media \& Society 20 (10): 3778-98. https://doi.org/10.1177/1461444818760819.

Tomer, S., A. Goldberg and B. Adini. 2015. "Socializing in Emergencies-A Review of the Use of Social Media in Emergency Situations." International Journal of Information Management 35 (5): 609-19.

Umejima, A., M. Miyabe, E. Aramaki and A. Nadamoto. 2011. “Tendency of Rumor and Correction Re-tweet on the Twitter during Disasters." Information Processing Society of Japan SIG Technical Reports 4: 1-6. http://id.nii. ac.jp/1001/00075459/.

Umihara, J. and M. Nishikitani. 2013. "Emergent Use of Twitter in the 2011 Tohoku Earthquake.” Prehospital \& Disaster Medicine 28 (5): 434-40. https://doi. org/10.1017/S1049023X13008704.

Wong, K. 2016. “Japanese Trends: Japan's Social Media Landscape in 2016." Btrax, January 26. Accessed February 6, 2017. https://blog.btrax.com/japanssocial-media-landscape-in-2016/.

Yoshitsugu, Y. [吉次 由美]. 2011. Higashi-nihon daishinsai ni miru daisaigai-ji no sōsharu media no yakuwari [ 東日本大震災に見る大災害時のソーシャルメディア の役割]. NHK Hōsō Bunka Kenkyūjo Media Kenkyū-bu [NHK放送文化研 究所 メディア研究部]. Accessed 25 January, 2018. https://www.nhk.or.jp/ bunken/summary/research/domestic/133.html. 


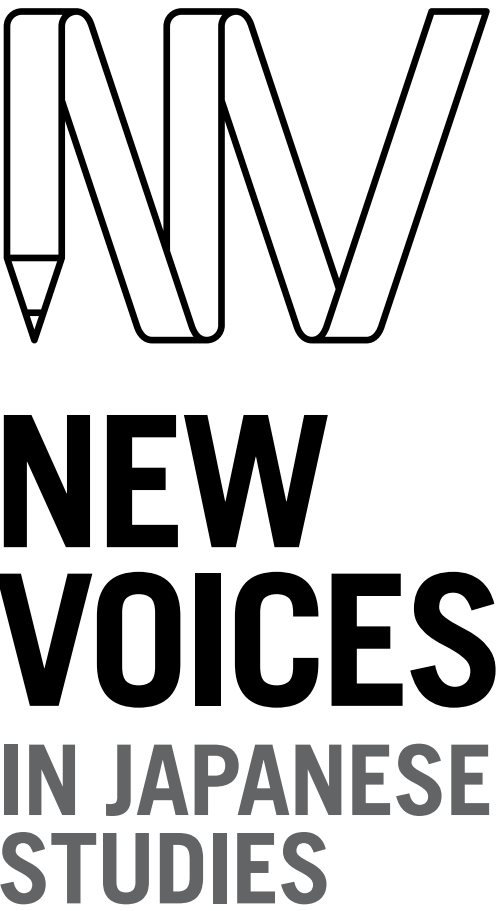

The Evolution of English Language Learners in Japan: Crossing Japan, the West, and South East Asia
THE EVOLUTION OF ENGLISH LANGUAGE LEARNERS IN JAPAN

CROSSING JAPAN, THE WEST, AND SOUTH EAST ASIA

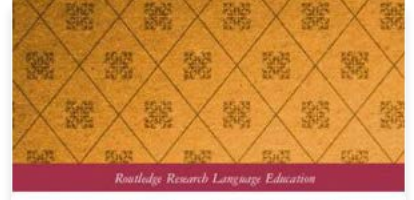

oko Kobayashi

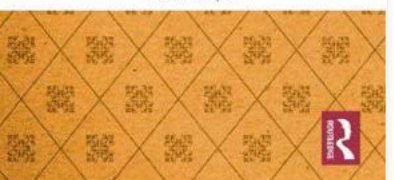

\section{YOKO KOBAYASHI.}

Routledge (New York), 2018.

144 pages.

ISBN 9781138631618.

https://doi.org/10.4324/9781315208749.

\section{Reviewed by}

Levi Durbidge

Monash University

\section{KEYWORDS}

applied linguistics; ASEAN; education policy; English; English language education; gender; internationalisation; language learning; mobility; study abroad

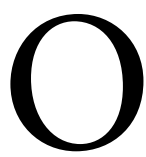
ne of the more perplexing research puzzles in the field of language education has been the ongoing failure of English language education in Japan. Despite decades of public investment, compulsory secondary-education language classes, and an army of Anglophone "native" teachers employed throughout Japan's education systems, many graduates of even top-tier universities lack basic English proficiency. As a corrective, the Japanese Ministry of Education, Culture, Sports, Science and Technology introduced compulsory foreign language classes to the 5th and 6th years of elementary school in 2011 and will extend them to the 3rd and 4th years in 2020. It is in the context of these controversial and widely discussed changes that Yoko Kobayashi presents a timely analysis of English language learning in Japan and the contradictions which seem to define it.

Beginning with an examination of the present state of English language education in Japan (Chapter 1), Kobayashi draws upon her extensive research

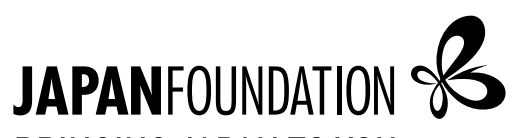

BRINGING JAPAN TO YOU

To link to this article:

https://doi.org/10.21159/nvjs.11.r-01

\section{ISSN 2205-3166}

New Voices in Japanese Studies is an interdisciplinary, peer-reviewed journal showcasing the work of emerging scholars with ties to Australia or New Zealand and research interests in Japan.

All articles can be downloaded free at newvoices.org.au

(c) The Japan Foundation, Sydney and Levi Durbidge, 2019

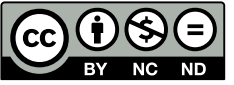

This work is licensed under a Creative Commons Attribution-NonCommercialNoDerivatives 4.0 International License. 
on second-language learning to explore evolving attitudes towards English and Japan's place in Asia. These themes are expanded through a review of research on inbound and outbound study abroad (Chapter 2) and case studies of Japanese learners studying English in ASEAN nations (Chapter 3). In these chapters, the ongoing dominance of the native speaker discourse, which grants prestige to Anglophone varieties of English, is contrasted with the growing popularity of ASEAN nations as destinations for Japanese learners of English. Drawing on her own research of English language schools in Singapore and private universities in Malaysia, Kobayashi argues that ASEAN nations' growing importance as education hubs offers opportunities for Japanese learners of English that are missing at home. Central among these is exposure to alternative models of English and intercultural knowledge, which can act as counterweights to the discourses of Western superiority prevalent in Japan.

Following this, in the most significant contribution of the volume, Kobayashi revisits and updates her pioneering work on the under-researched area of gender in language learning in Japan. Highlighting the ongoing overrepresentation of Japanese women in non-compulsory English language education, she interrogates women's views of English (Chapter 4) in relation to those of their male counterparts (Chapter 5). Critically, Kobayashi underscores the complexity of motivating factors among Japanese women learning English, including the discriminatory nature of Japanese business practices which result in many women using English to seek employment in foreignowned companies, both in Japan and overseas. In contrast, she demonstrates the effect that discourses of Japanese masculinity, combined with the low value placed on English ability by Japanese businesses, have in limiting the motivation of Japanese men to study English. A subsequent discussion on the disconnect between Japan's global economic success and its lacklustre English language education outcomes (Chapter 6) provides context for understanding the ongoing poor performance of English language education in Japan, particularly among men.

Developing these themes, Kobayashi presents an analysis of articles on English language learning taken from both men's (Chapter 7) and women's (Chapter 8) business magazines. Exposing the magazines' uncritical reproductions of gendered discourses on English language learning, she argues that they reinforce the primacy of the monolingual Japanese male in the workplace. Moreover, Kobayashi notes the magazines' preferences for non-academic sources (including self-proclaimed English experts and business leaders), highlighting how their lack of engagement with scholarship is linked to the inaccurate, essentialist view of global Englishes that they promote.

Altogether, the book addresses several key issues which continue to receive limited research attention, despite their significance. Paramount among these is the gendered nature of language learning in Japan and how societal expectations of men and women affect attitudes at all levels of education and into adulthood. Also significant are Kobayashi's incisive observations of top-tier universities' superficial efforts to internationalise. Perhaps the most compelling among these insights is the contradiction of universities holding up foreign-born teaching staff as evidence of internationalisation 
while simultaneously limiting their ability to effect any meaningful change on wider institutional practices.

Kobayashi goes on to problematise the notion of internationalisation in Japanese higher education, contending that it is unduly shaped by a "deeply ingrained societal association...with English and the West" (p. 16). This conceptualisation, she argues, overlooks the growing economic and cultural relevance of the Asian region to global society and marginalises populations of non-Western international students increasingly arriving from places such as China, Vietnam and South Korea. The issue is made further apparent in Kobayashi's questioning of the widely accepted assumption that Japan's economic future is dependent upon the success of its English education practices. She astutely points out that Japan's past economic success occurred in spite of the considered failure to cultivate widespread English-language proficiency. Taken together, these points highlight the importance of adopting more critical perspectives towards foreign language education in Japan and the ideological structures which underpin it.

While the book raises a number of important points, it is not without limitations. First, the book largely serves as a compendium of Kobayashi's previous research. While this is understandable given her investigations into areas that are often neglected, broader contextualisation of the results in related literature would have provided a more rounded and complete examination of the topic. Notably absent was Takahashi's (2012) influential work on Japanese women in Australia, particularly given the complementary themes of gender, study abroad and the influence of media discourse on attitudes towards English. Also, reference to efforts by both the Japanese government and private sector to develop an internationalised elite through undertakings such as the Tobitate, Kakehashi and Tomodachi programs would have provided important context to the criticisms made of universities' resistance to reform. Finally, while the focus is understandably on English language education, discussion of a more diverse, multilingual Japan-driven by the possibility of many of the processes Kobayashi identifies-would have been a pertinent addition to the concluding remarks.

In summary, Kobayashi has made an important contribution to our understanding of English language education in Japan. In particular, she has illuminated the impact of gendered discourse on motivation, engagement and the perceived relevance of English among Japanese learners. Furthermore, this volume points towards key changes and opportunities for language education in Japan offered by the growing importance and aspirations of ASEAN nations and the wider Asia region in general. Ultimately, Kobayashi has drawn attention to the underlying ideological factors which continue to hold back language learners in Japan, making this volume vital reading as the nation approaches a future where it must renegotiate its place in Asia and the world.

\section{REFERENCES}

Takahashi, K. 2012. Language Learning, Gender and Desire: Japanese Women on the Move. New York: Multilingual Matters. https:/doi.org/10.21832/9781847698551. 


\section{Japan: History and Culture from Classical to Cool}

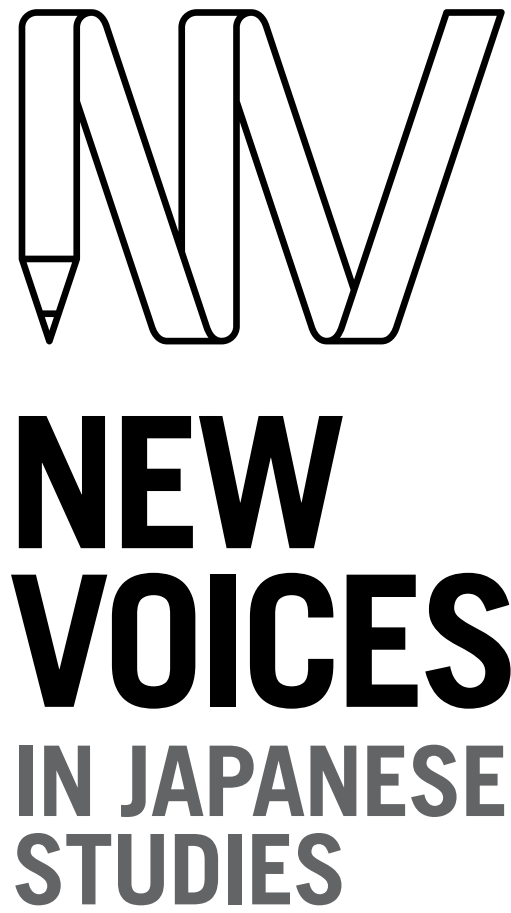

Reviewed by

Gwyn McClelland

Monash University

\section{KEYWORDS}

contemporary; culture; history; literature; Occupation; politics; popular culture; state; tradition; World War II

$\mathrm{N}$ ancy K. Stalker's Japan: History and Culture from Classical to Cool is a tertiary-level history textbook of Japan, bridging the premodern to modern periods. As a teacher of Japanese history, I know that finding a suitable textbook for the history teacher in the tertiary sector is not always easy. See, for example, Marius Jansen's The Making of Modern Japan (2000), or Hall's The Cambridge History of Japan (1991). The former is only concerned with modern Japan, focusing on politics and influencers, while the latter is in six volumes, making it inappropriate as a textbook. Whereas many history textbooks tend to treat culture, gender and aesthetics as an afterthought, the author of Japan: History and Culture asserts their integral importance to Japanese history (p. vii) - a perspective arguably in keeping with her expertise as Professor in Cultural and Gender Studies (20th Century) at the University of Hawaii. Her argument in this book is that by paying careful attention to the currents of literature, culture, religion, gender and art, the context and background for understanding Japanese history will come alive for students.

The chapters are arranged in largely chronological and thematic order, although there is some back and forth between periods. The book begins with a consideration of the early Japanese state and its origins, including Shinto

JAPANFOUNDATION 8 BRINGING JAPAN TO YOU

To link to this article: https://doi.org/10.21159/nvjs.11.r-02

\section{ISSN 2205-3166}

New Voices in Japanese Studies is an interdisciplinary, peer-reviewed journal showcasing the work of emerging scholars with ties to Australia or New Zealand and research interests in Japan.

All articles can be downloaded free at $\underline{\text { newvoices.org.au }}$

(C) The Japan Foundation, Sydney and Gwyn McClelland, 2019

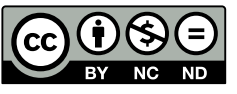

This work is licensed under a Creative Commons Attribution-NonCommercialNoDerivatives 4.0 International License. 
mythology and the Buddhist foundations of Japan. The author describes early influences from East Asia of Korean (Paekche) and Chinese origin, setting Japan's development in transregional and international context. Major historical events are examined in detail, including the development of the early centralised state, the 'rise of a warrior class,' and the period of political foment, unrest and civil war during the twelfth to fifteenth centuries which is characterised as 'disintegration and re-integration'. Stalker discusses how some religious movements were appropriated by the state for political gain, while other movements-such as those led by militant Buddhist lay believers and the monastic armies of the late sixteenth century (pp. 113-16)-were dissident and disruptive of the state. Dispersed through the historical discussions are analyses of culture, religion and society on subjects such as Noh drama (pp. 99-102), Zen movements (p. 167) and even 'Interior Architectural Décor' (p. 125). The latter, for example, is described in the chapter on 'Disintegration and Reunification' after a thorough and important discussion of the warring period. The integration of the cultural elements support and accompany vital discussions about war, power and politics, achieving the author's aim of providing useful and contextualised descriptions of 'aesthetics and tradition [which] occupy a central role in modern Japanese national identity' (p. vii).

Due to the wide range of subject matter covered, the discussion does not always progress chronologically. The Edo period, for example, is explored over two chapters, describing first the political climate of the Tokugawa Shogunate, and second how this period of relative peace across Japan resulted in the production of considerable cultural arts, drama and literature. In this way, the book shows how the political aspects of history are interwoven with the arts and literature, and vice versa. As a result, some of Chapter 7 reads as a critique of Japanese literature rather than as a history textbook. This approach is innovative and the discussion of poets, authors and important literary movements lends itself well to class discussions and may also assist students in gaining a better understanding of the period under study. One example is how the work, life and travels of Matsuo Bashō, a significant poet and teacher of the Tokugawa era, is described at some length (pp. 184-186), giving insight into the environment and socio-cultural context of Edo Japan.

The book considers the history and culture of twentieth-century (and finally twenty-first century) Japan over the final four chapters. Topics considered in this section range from Marxism to the board game suguroku, department stores and an introduction to the feminist writer, Raicho Hiratsuka. Stalker usefully contextualises the twentieth-century experience of war and militarisation, from Japan's colonial conquests and the military comfort women system instituted during World War II to the occupation of Korea, Taiwan and multiple Pacific islands. The final chapter is titled 'Cool Japan as Cultural Superpower', and reviews economic development, social issues and gender concerns in modern Japan (1980 to present). Stalker includes here varied elements of 'Cool Japan' such as literature (Haruki Murakami), anime, cosplay, kyara, J-pop and food.

Another notable aspect of the book is its acknowledgement of lesser known (but nonetheless important) voices and movements through the ages. Japan 
historians' tendency to focus on the 'great men of history' should be subverted, especially in our classrooms. This textbook goes some way to balancing the record, picking up on significant female contributions to politics, society and literature and by noting the situations of minority groups such as burakumin, Ainu and wider mass culture, as opposed to focusing solely on powerbrokers and elites. Perhaps one shortcoming of the book is an over-reliance on EuroAmerican-centric Japanese Studies texts. It would also have been helpful for those with Japanese language ability to have Japanese-language sources included in the resource lists at the end of each chapter.

Japan: History and Culture is an entertaining and concise textbook for university undergraduate and postgraduate history teachers or senior high school students. A particularly practical feature of this book is that each chapter ends with a postscript of further recommended reading and films which assists the teacher (and student) in exploring related visual and supplementary resources. Aside from being useful in class, this book will also be a helpful reference for academics to support astute teaching, writing and lecturing.

\section{REFERENCES}

Hall, J. W. 1991. The Cambridge History of Japan. 6 vols. Cambridge: Cambridge University Press.

Jansen, M. B. 2002. The Making of Modern Japan. Cambridge, Mass.: Belknap Press.

\section{REVIEW}




\section{Diva Nation: Female Icons from Japanese Cultural History}

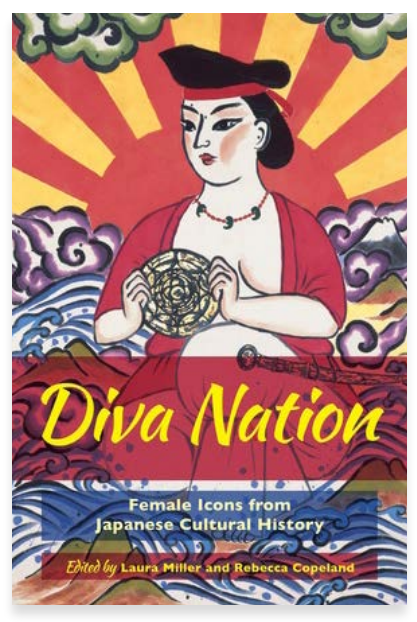

LAURA MILLER AND REBECCA COPELAND, EDS.

University of California Press

(Oakland), 2018.

264 pages.

ISBN 9780520297739.

https://doi.org/10.1525/california/

9780520297722.001.0001.

\section{Reviewed by}

Rebecca Hausler

The University of Queensland

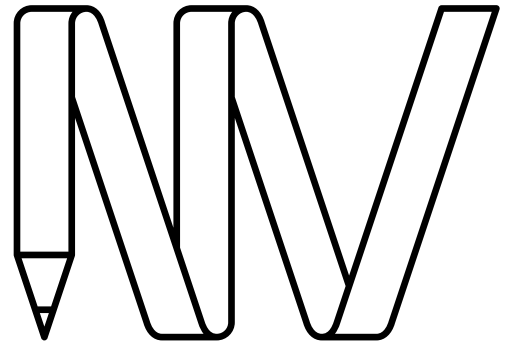

NEW

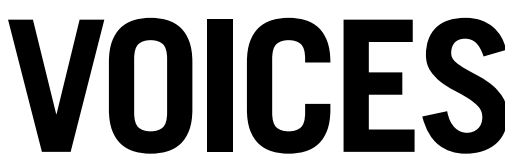

IN JAPANESE STUDIES

\section{KEYWORDS}

contemporary; gender; history; performance; popular culture; sexuality; shōjo; social and cultural identity; women

\section{JAPANFOUNDATION 8 BRINGING JAPAN TO YOU}

To link to this article:

https://doi.org/10.21159/nvjs.11.r-03

\section{ISSN 2205-3166}

New Voices in Japanese Studies is an interdisciplinary, peer-reviewed journal showcasing the work of emerging scholars with ties to Australia or New Zealand and research interests in Japan.

All articles can be downloaded free at newvoices.org.au

(c) The Japan Foundation, Sydney and Rebecca Hausler, 2019

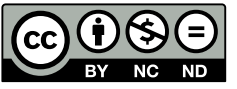

This work is licensed under a Creative Commons Attribution-NonCommercialNoDerivatives 4.0 International License. 
between these Japanese 'diva' women and their less-visible counterparts and supporters, both in Japan and across the globe. As Miller and Copeland state, "The diva writes large what most women live but cannot speak" (8).

The diversity of the women featured within Diva Nation suggests that there is no one single or circumscribable definition of a diva. Instead, it is the diva's defiance of patriarchal and heteronormative assumptions that define her. Her excessive performances mirror and critique those of the powerful men that seek to rein her in, giving rise to questions of "what is natural, what is normal, [and] what is culturally appropriate" (4-5). To quote from Wayne Koestenbaum's work, The Queen's Throat: Opera, Homosexuality and the Mystery of Desire, a text that is cited repeatedly in Diva Nation's introduction, in witnessing the diva we "are shattered by the liberating spectacle of [her] standing up for herself against propriety" (Koestenbaum 1994, 113). Here, Koestenbaum emphasises the importance of the diva's audience not only as witnesses to her performance but also as sympathisers to her cause, destabilising the foundation of public support which holds these standards of propriety in place. Diva Nation gives attention to this "shifting social ground" (1), focusing not only on the diva herself, but on her audiences as well.

The book's ten case studies of Japanese female icons show the diva to be a transgressive force which refuses to be enclosed by simplistic borders of geography, gender or genre. Think of radical artist and peace activist Yoko Ono, manga artist Shungiku Uchida, or the dancer and founder of kabuki theatre Izumo no Okuni: Ono's recognition and reputation extends well beyond the borders of Japan; Okuni's performances in exotic male attire contested sexual and gendered norms; while Uchida refuses to be constrained to any one artistic genre as a singer, actress, magna artist, novelist and critic. Diva Nation shows that such women are daring not only because of their perverse and obstinate behaviours which "expose efforts to control femininity and the female body" (7), but because they make sure that everyone is watching.

The case studies also illustrate the important role of the audience: the diva's dramatic displays are not only a form of protest but become a source of pleasure for those who watch. Tomoko Aoyama's chapter on the goddess Ame no Uzume, whose comical nude dancing resolves a crisis within the heavenly realm, and Christine R. Yano's chapter which includes analyses of the crossgendered drag performances of Hibari Misora, provide excellent examples of such audience-derived pleasure and illustrate the way that these performances unsettle conventional boundaries "in a contained but dramatic fashion" (108). As Diva Nation demonstrates, these boundaries include but are not limited to "national boundaries" (5), "boundaries of genre expectations" (17) and "boundaries of normative gender and sexuality" (137).

Each chapter challenges assumptions about culturally significant divas and their disruptive presence in patriarchal Japan. The chapters are skillfully ordered, following a natural thematic and historical progression. Chapters one through four trace historical examples of divadom in Japan, from goddesses to kabuki dancers, highlighting their ongoing impact by analysing how depictions of these figures have manifested within contemporary literary, 
artistic and cultural spheres. Chapters five and six explore late twentiethcentury interpretations of the diva through musical and artistic performances by Hibari-chan and Ono, illustrating the ways in which they evolved both professionally and personally over the course of a lifetime in the media spotlight. Finally, chapters seven through ten showcase divas of the new millennium who challenge assumptions of sexuality, gender performance and femininity in unexpected and provocative ways. For example, Jan Bardsley's chapter on transgender celebrity and beauty guru IKKO reveals the complexities surrounding the success of a middle-aged and non-binary transwoman in neoliberal Japan, while Masafumi Monden's chapter analyses how figure skater Mao Asada's "demure, good girl persona” (202) allows her to avoid criticisms often levelled at powerful women. These two chapters illustrate that there is more than one way to defy culturally structured expectations of women in Japan. Furthermore, the popularity of these figures highlights that contemporary women are receptive to the disruptive ideas they put forth, challenging Japan's entrenched gender norms that at times continue to shape understandings of women as ryōsai kenbo (良妻賢母; 'good wives and wise mothers').

Somewhat uniquely for an academic monograph, the afterword, "Diva tte nan desu ka? (What is a Diva?)", takes the form of a manga work by 'vagina artist' Rokudenashiko (whose artist name translates literally as 'good-for-nothing girl'), featuring the character Manko-chan ('Miss Pussy') (203). Given the importance of the spectacle in diva lore, this visual piece fits well within the volume; however, arguably it would have had greater impact if combined with a concluding chapter, as the volume finishes rather abruptly.

Despite this, Diva Nation reads as a very cohesive volume, and furthers the work explored in Laura Miller and Jan Bardsley's 2005 collection Bad Girls of Japan (which also featured a chapter by Diva Nation editor Rebecca Copeland), and the 2009 collection Girl Reading Girl in Japan (edited by Tomoko Aoyama and Barbara Hartley, whose work also features in Diva Nation). Both of these earlier works focus on the cultural significance of Japanese girls and women, highlighting their subversive practices and potentiality. Diva Nation builds on this by narrating a long history of transgressive women who seek to disrupt hegemonic notions of gender, sexuality and societal roles in Japan. In doing so, it defines divas as ever-present beacons of resistance in a phallocentric world, and moreover, as Japanese cultural icons that aspiring divas everywhere can look towards.

This collection will be valuable not only to those interested in Japanese studies, but also for those with an interest in gender studies, queer studies and any field engaging with minority cultural or subcultural groups.

\section{REFERENCES}

Aoyama, T. and B. Hartley, eds. 2009. Girl Reading Girl in Japan. New York: Routledge. Koestenbaum, W. 1994. The Queen's Throat: Opera, Homosexuality, and the Mystery of Desire. New York: Vintage Books.

Miller, L., and J. Bardsley, eds. 2005. Bad Girls ofJapan. New York: Palgrave Macmillan.

Rebecca Hausler New Voices in Japanese Studies, Vol. 11, 2019, pp. 105-107 